Florida International University

FIU Digital Commons

3-22-2019

\title{
Uprooting and Rerooting Religious Identities: Understanding the Experience of Self-Identified Christian Millennial Migrants from South America in Miami
}

\author{
Ernesto M. Fiocchetto \\ Florida International University, efioc001@fiu.edu
}

Follow this and additional works at: https://digitalcommons.fiu.edu/etd

Part of the Christianity Commons, Latin American Studies Commons, Migration Studies Commons, Missions and World Christianity Commons, and the Sociology of Religion Commons

\section{Recommended Citation}

Fiocchetto, Ernesto M., "Uprooting and Rerooting Religious Identities: Understanding the Experience of Self-Identified Christian Millennial Migrants from South America in Miami" (2019). FIU Electronic Theses and Dissertations. 4027.

https://digitalcommons.fiu.edu/etd/4027

This work is brought to you for free and open access by the University Graduate School at FIU Digital Commons. It has been accepted for inclusion in FIU Electronic Theses and Dissertations by an authorized administrator of FIU Digital Commons. For more information, please contact dcc@fiu.edu. 


\section{FLORIDA INTERNATIONAL UNIVERSITY}

Miami, Florida

\section{UPROOTING AND REROOTING RELIGIOUS IDENTITIES: \\ UNDERSTANDING THE EXPERIENCE OF SELF-IDENTIFIED CHRISTIAN \\ MILLENNIAL MIGRANTS FROM SOUTH AMERICA IN MIAMI}

A thesis submitted in partial fulfillment of

the requirements for the degree of

MASTER OF ARTS

in

RELIGIOUS STUDIES

by

Ernesto Mario Alberto Fiocchetto 
To: Dean John F. Stack, Jr.

Steven J. Green School of International and Public Affairs

This thesis, written by Ernesto Mario Alberto Fiocchetto, and entitled Uprooting and Rerooting Religious Identities: Understanding the Experience of Self-Identified Christian Millennial Migrants from South America in Miami, having been approved in respect to style and intellectual content, is referred to you four judgment.

We have read this thesis and recommend that it be approved.

$\begin{array}{r}\hline \text { Albert Kafui Wuaku } \\ \hline \text { Whitney Bauman } \\ \hline \text { Ana Maria Bidegain, Major Professor }\end{array}$

Date of Defense: March 22, 2019

The thesis of Ernesto Mario Alberto Fiocchetto is approved.

Dean John F. Stack Steven J. Green School of International and Public Affairs

Andrés G. Gil Vice President for Research and Economic Development and Dean of the University Graduate School

Florida International University, 2019 


\section{DEDICATION}

I dedicate this thesis to my parents and siblings, now that we have experienced that love has no boundaries. Your support keeps me going. I also dedicate this work to my friends who continuously teach me and reinforce in me the importance of thinking, believing, and loving. These are the roots that I do not want to lose. 


\section{ACKNOWLEDGMENTS}

It was November 2015, and I showed up to class for a graduate course on Religion, Politics, and Gender in Latin America hosted by my beloved Universidad Nacional de Cuyo in Mendoza, Argentina. The invited lecturer was a Uruguayan scholar coming from Florida International University. That is how I met Dr. Ana Maria Bidegain, and that is how this adventure started. I am deeply grateful to this professor-motherfriend, who teaches me how to live and how to believe. Without her presence throughout these two years in Miami, this work would be less significant.

I wish to thank Dr. Whitney Bauman for his patience and support in the process of reflecting and writing this thesis. His enthusiasm for my research and his profound insights inspire and challenge me to grow, search, and think. I also want to thank Dr. Sarah Mahler and Dr. Albert Wuaku, who generously helped me throughout the process of the thesis. I am truly grateful to Dr. Ulrich Oslender, who supported me in a tough moment and whose presence has been precious for me. My sincere gratitude to the entire faculty of the Department of Religious Studies and my colleagues in Graduate School: particularly, I would like to thank Stephanie Londono, Azalie Duque, Luz Aviles and Yusimi Sayus for their help, affection, and good humor.

Finally, I would like to thank all the millennial believers who participated in this research. They selflessly shared significant aspects of their lives and religious searches. They taught me more than they can possibly imagine. 


\section{ABSTRACT OF THE THESIS \\ UPROOTING AND REROOTING RELIGIOUS IDENTITIES: \\ UNDERSTANDING THE EXPERIENCE OF SELF-IDENTIFIED CHRISTIAN \\ MILLENNIAL MIGRANTS FROM SOUTH AMERICA IN MIAMI}

by

Ernesto Mario Alberto Fiocchetto

Florida International University, 2019

Miami, Florida

Professor Ana Maria Bidegain, Major Professor

This study aims to understand the social configuration of religious identities of South American millennial migrants who self-identify as Christian in Miami-Dade County. The work entails an extensive description of the context of the study subjects, deep theoretical insight on religion and identity, and a qualitative approach. The narratives of the South American millennial migrants' process of religious identity configuration and the relationships they establish with religious institutions emerged from in-depth interviews and focus group sessions. The analysis of such narratives grounded middle-range theory that makes sense of the study subjects and can potentially shed light on other experiences in pluralistic, migratory contexts. In the end, the study offers a significant contribution to the under-explored intersection between the processes of identity configuration, religious institutions, and migration in Miami-Dade County from the perspective of South American millennial migrants who self-identify as Christians. 


\section{TABLE OF CONTENTS}

CHAPTER

PAGE

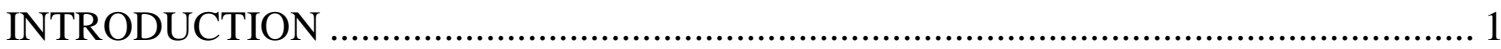

1. The Research Problem and Its Context .................................................................... 1

2. Epistemological Paradigm and Methodological Perspective ...................................... 4

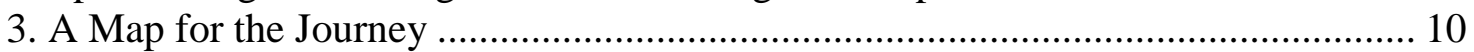

CHAPTER 1: Unpacking the Baggage. The Context of South American Millennials in Miami, a Migrant Metropolis with a Diverse Religious Landscape .......................... 12

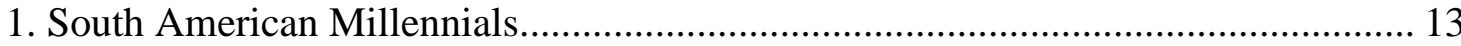

1.1. Socio-politico-economic Context: South American Millennials in the Times of Neoliberalism and Post-Neoliberalism.......................................................16

1.2. Religious Context: Changes in the South American Religious Landscape ..........23

1.3. Migratory Context: Mobility and Migration in Millennials' South America.......31

2. South American Migrants and Believers in Miami.................................................. 36

2.1. South American Migrants in the U.S.: some traits ..............................................36

2.2. Miami, an Immigrant City Chosen by South American Millennials.....................38

2.3. Miami, a Migrant Metropolis with a Diverse Religious Landscape ......................41

CHAPTER 2: Religious Identities in Late Modernity ................................................... 47

1. Towards an Understanding of Late Modernity: Three Main Contributions .............. 48

1.1. Ulrich Beck: Second Modernity and the World Risk Society.............................50

1.2. Zygmunt Bauman: Liquid Modernity and Consumer Society .............................54

1.3. Anthony Giddens: Late Modernity and Post-Traditional Society .......................58

2. Toward the Comprehension of Religion in High Modernity: The Contribution of

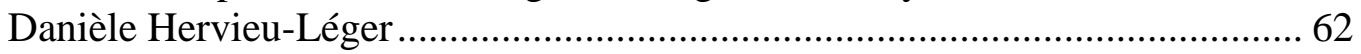

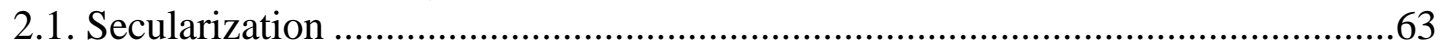

2.2. Religion as a Chain of Memory.....................................................................67

2.3. Some Paradoxes of Religious Modernity ………………..................................74

3. Toward the Comprehension of Identities: The Contributions of Francoise Dubet

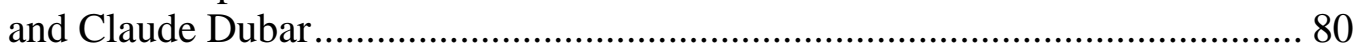

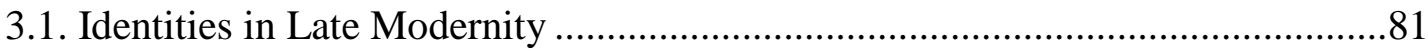

3.2. Identities in Francoise Dubet's Sociology of Experience ...................................86

3.3. Claude Dubar and the Crisis of Identities.........................................................91

CHAPTER 3: Configuring Religious Identities in a Migratory Context. The Experience of South American Christian Millennial Migrants in Miami................. 99

1. Defining Migrants' Processes of Religious Identity Configuration......................... 100

2. Uprooting and Rerooting in Late Modernity.......................................................... 102

2.1. Risks There and Here: Cultural Matrix and New Soils for Meaningful Roots

2.2. An Individual Task: Fitting in the Religious Market of Miami 108 
2.3. Reflecting on their Identities: Making Meaningful Memory of Significant Spaces and Times .....................................................................................112

3. Freelance Believers I: South American Millennial Migrants and the Process of Individuation of Beliefs in Miami ............................................................... 116

3.1. Resignifying the South American Matrix and Searching for Authenticity .......119

3.2. Migrating, Circulating, and Searching for Their Own Benefits ........................123

3.3. Avoiding Self-Alienation and Reflexively Considering the Ground of Their Actions

4. Freelance Believers II: South American Millennial Migrants and Their

Relationships to Religious Institutions in Miami ........................................... 130

4.1. Putting Institutions into Perspective ...........................................................132

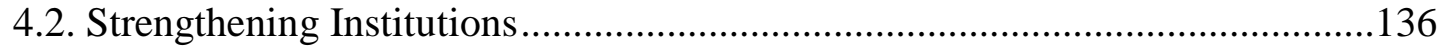

4.3. Re-Thinking Religious Institutions ................................................................139

CONCLUSIONS: Uprooting and Rerooting Religious Identities ................................... 147

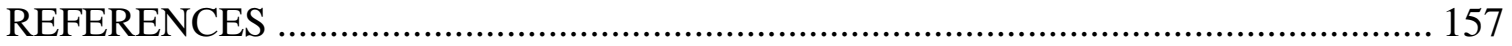




\section{INTRODUCTION}

\section{The Research Problem and Its Context}

Miami-Dade County is one of the five counties with the most South Americans in the U.S. Indeed, from 2012 to 2016, 25 percent of the immigrants from South America to the United States settled in Florida. Moreover, the estimation of South American migrants in Miami-Dade County is over 10 percent of the population consisting of more than 250,000 individuals. With more than 50 percent of its population having been born in other countries and more than 80 percent having foreign-born parents, Miami is proportionately the most immigrant city of any major metropolitan area in the United States. ${ }^{1}$ In the words of Stepick, Rey, and Mahler, "Miami is the quintessential new immigrant city."2

Around 30 percent of Miami-Dade County are millennials, young men and women in their twenties and thirties, and therefore, this generation cohort is the current most numerous age group in this city. ${ }^{3}$ Consequently, the presence of South American millennial migrants is crucial in the life of Miami-Dade County, as it is in many cities of the U.S.

\footnotetext{
${ }^{1}$ Jie Zong and Janne Batalova, "South American Immigrants in the United States," Migration Information Source (November, 2018). https://www.migrationpolicy.org/article/south-american-immigrants-unitedstates/

${ }^{2}$ Alex Stepick, Terry Rey, and Sarah J. Mahler, eds., Churches and Charity in the Immigrant City: Religion, Immigration, and Civic Engagement in Miami. (New Brunswick, New Jersey: Rutgers University Press, 2009), 17.

${ }^{3}$ United States Census Bureau, "American FactFinder: Age and Sex 2013-2017 American Community Survey 5-Year Estimates," accessed January 14, 2019. https://factfinder.census.gov/faces/tableservices/jsf/pages/productview.xhtml?pid=ACS_17_5YR_S0101\& prodType $=$ table
} 
Thousands of South American millennial migrants have arrived in Miami during the last decades. They arrive with their history, family, social and cultural features, values, and religion. Indeed, 'there is no doubt that religion is central to immigrants' personal and communal identity,"4 and given the characteristics of the southern subcontinent, the role that Christianity plays in the life of South American millennial migrants is crucial. Hence studying the intersection between the processes of identity configuration, religious institutions, and migration from the perspective of South American millennial migrant who self-identify as Christians in Miami-Dade County is significant to the Sociology of Religion, the Social Sciences of Religion, and Religious Studies.

According to Stepick, Rey, and Mahler, "the role of religion in Miami is largely unknown simply because very few scholars have seriously or systematically examined it." ${ }^{5}$ Studies on the said intersection is thus not a sufficiently researched field. In fact, studies have been done on religious experiences in Miami with other foci. Thomas Tweed, for example, focuses on a Cuban Catholic shrine in Miami. ${ }^{6}$ In his most notable book, he offers a "theory of religion that makes sense of the religious life of transnational migrants."7 Yvonne Conde focuses on the experiences of displaced Cuban children in the

\footnotetext{
${ }^{4}$ Stepick, Rey, and Mahler, eds., Churches and Charity in the Immigrant City, 5.

5 Ibid., 17.

${ }^{6}$ See Thomas Tweed, Our Lady of the Exile: Diasporic Religion at a Cuban Catholic Shrine in Miami (New York: Oxford University Press, 1997) and Thomas Tweed, Crossing and Dwelling: A Theory of Religion, (Cambridge, Massachusetts, and London: Harvard University Press, 2008), Kindle Edition.

${ }^{7}$ Tweed, Crossing and Dwelling, loc. 60 of 3162, Kindle.
} 
Pedro Pan project. ${ }^{8}$ Miguel de la Torre, focusing on the relation between politics, migration, and religion, gives an account of the struggle for Cuba in the streets of Miami. ${ }^{9}$ These three great studies do not focus on the particularities of the intersection between millennial transnational immigrants and religion, and they are focused mainly on Cuban and/or Caribbean transnational migrants, rather than on Latin Americans.

Studies have also been done on the role of immigrant religious organizations and their civic engagement in Miami. Based on ethnographic research, Stepick, Rey, and Mahler edited a book in which several contributing authors examine the role and significance of immigrant congregations and African American churches in Miami by addressing the relations among religion, immigration, and civic engagement. ${ }^{10}$ They offer research about migrants from different countries, and, especially in the third part of the book, they address some issues regarding young migrants and religion from the perspective of religious organizations and civic engagement. However, I was unable to find studies that specifically focused on the intersection between the processes of identity configuration, religious institutions, and migration from the perspective of believers. I consider the intersection of these to be an essential theme since studies focusing on religious organizations do not entirely capture the logic behind religious subject formation.

\footnotetext{
${ }^{8}$ Yvonne Conde, Operation Pedro Pan: The Untold Exodus of 14,048 Cuban Children (New York: Routledge, 1999).

${ }^{9}$ Miguel de la Torre, La Lucha for Cuba: Religion and Politics on the Streets of Miami (Berkeley: University of California Press, 2003).

${ }^{10}$ Stepick, Rey, and Mahler, eds., Churches and Charity in the Immigrant City.
} 
Therefore, the purpose of this qualitative study is to explore the intersection of the processes of identity configuration, religious institutions, and migration from the perspective of South American millennial migrant who self-identify as Christians in Miami-Dade County. This work collects and analyzes descriptive data on the social configuration of religious identities of South American millennial migrants who selfidentify as Christians in Miami-Dade County and in order to contribute to a better understanding of this process.

In this regard, two questions guide my research:

- How do South American millennial migrants who self-identify as Christians configure their religious identities in Miami-Dade County?

- How can we understand the relationships that South American millennial migrants who self-identify as Christians have to religious institutions in Miami-Dade County through the process of configuration of religious identities?

\section{Epistemological Paradigm and Methodological Perspective}

Given such research questions, it is necessary to clarify some epistemological and methodological considerations. Based on an Ancient Greek paradigms, the French sociologist Claude Dubar synthesizes two possible approaches when studying identities. On the one hand, Parmenides, the philosopher of the changeless, thought that we could speak and think only of what exists, and what exists is uncreated and imperishable because it is whole, unchanging, and complete. It was not nor will it be different than it is now. Therefore, the understanding of the nature of human beings implies elucidating the eternal essence of each human being, an essential belonging that is a priori, immutable 
throughout time and space, and inherited by nature. This is the essentialist paradigm regarding identities.

On the other hand, Heraclitus, the philosopher of change, argued Panta rei (everything flows), and therefore, that no human being ever steps in the same river twice, for it is not the same river, and he/she is not the same human being. Thus, there are no such eternal essences; rather, there are incidental existences since everything is in constant change. Hence, identities depend on time and space; they change throughout the history of individuals and societies. We use words that, in a given context, are useful to name some modes of identification that are historically varying. This is the existentialist or nominalist paradigm regarding identities. ${ }^{11}$

The epistemological paradigm that frames this study on religious identities is one based on existentialism. More specifically, the paradigm is constructivist since it aims to deconstruct and reconstruct the processes of the configuration of religious identities from the perspective of South American millennial migrants, who self-identify as Christians, in Miami-Dade County in order to achieve a better understanding of such a process.

This clarification might seem irrelevant or intellectually baroque. However, many present theoretical discussions are based on the tensions between the essentialist and existentialist paradigms. Further evidence of this can be found in the debates on the use of the term identification against identity. Authors like Roger Brubaker and Frederick

\footnotetext{
${ }^{11}$ Claude Dubar, La crisis de las identidades: La interpretación de una mutación (Barcelona: Ediciones Ballaterra, 2002), 9-12.
} 
Cooper ${ }^{12}$ and Richard Handler ${ }^{13}$ pervasively criticized the latter concept by linking it to the Parmenidean paradigm of essentialism. In order to express a more dynamic understanding of identities, they propose the use of the concept of identification.

In contrast, Martin Sökefekd argues that "the value of identity as an analytical category is its ability to accommodate the duality of essentialist and constructivist readings. The acknowledgment of the human ability to construct and deconstruct identities requires us to conceive of human individuals as reflexively acting selves."14 Further, "in the case of identity, dual hermeneutic leads to a reconceptualization of identity as qualified by the conditions of difference, multiplicity, and intersectionality." 15 I follow Sökefekd's perspective in this regard. In a few words, when I speak about identities, I considered them in the Panta Rei paradigm. Underpinning my research is an understanding of identities as relational and non-essential but also as embodied realities; hence, the process of configuration of identities is considered to be fluid, contextualized, and never completely defined. Moreover, I believe that the term identity has a history in the social sciences that does not allow us to attach it to a paradigm in contraposition to the other, much less to discard its use in the social sciences.

\footnotetext{
${ }^{12}$ Rogers Brubaker and Frederick Cooper, "Beyond 'Identity,"” Theory and Society 29, no.1 (2000): 1-47.

${ }^{13}$ Richard Handler, "On Dialogue and Destructive Analysis. Problems in Narrating nationalism and Ethnicity," Journal of Anthropological Research 41 (1985): 171-82; and "Is 'Identity' a Useful Crosscultural concept?," in Commemorations: The Politics of National Identity, ed. John Gillis (Princeton: Princeton University Press, 1994), 27-40.

${ }^{14}$ Martin Sökefeld, "Reconsidering Identity," Antrhopos 96, no. 2 (2001): 542.

${ }^{15}$ Ibid.: 527.
} 
The chosen constructivist perspective within the existentialist paradigm, together with the nature of the research problem and questions, entails an interdisciplinary approach that involves mainly Sociology of Religion and also draws from the field of Religious Studies, and the Social Sciences of Religion in general. Given that this research aims to reveal the South American millennial migrants' perspective, enabling their voices and perceptions to emerge in the study, I methodologically worked from a qualitative perspective. Qualitative methods allow researchers to get at the inner experience of individuals and to determine how meanings are formed in and through culture. ${ }^{16}$ Such methods imply a fluid, evolving, and dynamic approach that provides insight into the research problem and helps to advance new ideas, ground theories, and develop new hypotheses for prospective research.

Furthermore, this work aims to ground middle-range theory. In my perspective, grounding sociological research means three steps: an extensive description of concrete and complex contexts, a deep theoretical insight, and detailed and strategical fieldwork. In the framework of qualitative sociology, the research techniques used vary according to each step. In order to describe the contexts, I conducted intensive bibliographical research and I drew heavily from quantitative data analysis. While this is a qualitative study, quantitative data helps to recover some tendencies and features that are meaningful for understanding the context. The theoretical framework of this research was achieved mainly by intense bibliographical research on high-level and prominent scholars. Finally,

\footnotetext{
${ }^{16}$ Juliet Corbin and Anselm Strauss, Basics of Qualitative Research: Techniques and Procedures for Developing Grounded Theory (Los Angeles: Sage Publications Inc, 2008), 12-16.
} 
I conducted two different qualitative techniques, namely focus group sessions and indepth interviews, to address fieldwork.

Drawing heavily from the methodology of grounded theory, this work offers some middle-range theoretical contributions generated from the continuous feedback between data collection and analysis. ${ }^{17}$ I started by conducting an exploratory focus group session with five participants in November 2018. Then, I developed a model questionnaire for the in-depth interviews based on the analysis of the focus groups session. During December 2018, I conducted the first of three in-depth interviews. I analyzed the collected data, and I started to identify categories and connections among such categories. This step enriched the model questionnaire. Four interviews were conducted during the first two weeks of January 2019. Between each interview, I repeated the processes of analysis and categorization, and some connective concepts emerged. These concepts were developed through constant comparison with additional data obtained in each new interview. As a result, I obtained a comprehensive, though still messy, conceptual map of the results. At the end of January, I conducted a final focus group session that helped me test and tune some concepts and make decisions regarding the final order of the presentation of the results. Finally, I considered it was necessary to conduct the last interview based on the scheme of the results in order to test and improve my work. To facilitate the data analysis I employed the software Atlas.ti throughout the process.

The questions that guide this study are about South American millennial migrants who self-identify as Christians in Miami-Dade County. Therefore, the study subjects are

\footnotetext{
${ }^{17}$ Ian Dey, Grounding Grounded Theory: Ghidelines for Qualitative Inquiry (San Diego and London: Academic Press, 1999), 1-3.
} 
self-identified Christian men and women who are first generation South American transnational migrants between the ages of 20 and 39, and have lived in Miami-Dade County for three to ten years. I have chosen to work with Christians because around 70 percent of the believers in Miami report affiliation to different denominations of Christianity. As I previously stated, I chose to work with South Americans because it is not a sufficiently researched population. My personal interests and the possibilities of comparing results from this study against my previous research also motivated such a decision. Specifically, 16 individuals that meet these characteristics voluntarily participated in this study. Five attended the first focus group session; I chose three of them for the in-depth interviews; in addition, I invited another five individuals for new in-depth interviews; the second focus group session was formed by six new volunteers. The 16 participants were equally divided among women and men. They were from Argentina, Brazil, Chile, Colombia, Ecuador, Paraguay, Peru, and Venezuela.

The study subjects show the importance and richness of this research. However, they also demonstrate its limit. The descriptions and middle-range theoretical concepts that resulted from this thesis are valid for these subjects and others in similar contexts. Generalizations of these results can lead us to misinterpretations. Nevertheless, I hope that this contribution could potentially shed light on other subjects and contexts that are related to the processes of religious identity configuration. At this point, it is worth mentioning that, throughout the text, the study subjects receive different titles than South American millennial migrants who self-identify as Christians in Miami-Dade County. For example, I sometimes refer to them as millennial migrants in Miami, Christian migrants, South American millennials, and so on. By doing this, I tried to make the text more 
reader-friendly and lucid. Decontextualizing such short references in order to generalize or apply conclusions to other subjects or places is not my intention.

\section{A Map for the Journey}

In order to meet the goals of this research, the results are presented in three chapters. Chapter one develops the context of South American millennial migrants in Miami and addresses the meaning of the term millennial and some characteristics of South America that are relevant for this research, such as the socio-politico-economic contexts of these migrants. Finally, the chapter describes some features of Miami and depicts the landscape where they arrive.

Chapter two grounds the study on the theoretical approaches that frame the research problem. Such a theoretical framework helped me better understand and critically address the fieldwork. The text, thus, tackles the nuclear concepts of this work, namely religion and identity, in the general context of Late Modernity.

The last chapter develops the findings of the two questions that guide this research. The South American millennial migrants' process of configuration of religious identities in Miami and the relationships they establish with religious institutions will be tackled in the perspective of the concepts drawn from chapter two and the new theoretical perspectives that emerged from the in-depth interviews and the focus group sessions.

In conclusion, the study makes a significant contribution to the under-explored intersection between the processes of identity configuration, religious institutions, and migration from the perspective of South American millennial migrants who self-identify as Christians in Miami-Dade County. Thus, it broadens the already existent descriptive 
qualitative data about religion and migration in Miami. Since it reveals new aspects of the aforementioned intersection, the outcomes of this work not only shed light on the phenomena of how religion is experienced and practiced in Miami-Dade County, but it could also shed light on other experiences in pluralistic, migratory contexts. Finally, in an era of globalized realities, many people are forming their religious identities in pluralistic contexts outside of religious institutions. This study could potentially contribute to the literature on both religion and identity theory in an era of globalization. 


\section{CHAPTER 1: Unpacking the Baggage. The Context of South American Millennials in Miami, a Migrant Metropolis with a Diverse Religious Landscape}

South American millennials arrive in Miami as immigrants. They do not come alone. Inside their baggage, they bring history, family, social and cultural features, values, and religion. It is impossible to deeply understand how they configure their religious identities as migrants in Miami if we do not unpack this baggage.

To this end, this chapter addresses firstly the meaning of the term millennials and some relevant features of such a generational cohort in South America. The first part of the chapter develops the socio-politico-economic context of these migrants, the religious landscape, and the migratory situation in their countries of origin. This section has been particularly challenging for several reasons. South American migrants in Miami continue to be an under-explored group. Indeed, most of the scholarly works are on Latin American immigrants or immigrants from particular countries, specifically Cuba and Haiti. While migrants from South America share several cultural characteristics with Latin American migrants in general, some specific features make them very different study subjects from Central American and Caribbean migrants. Moreover, such specificities also vary from country to country within the southern continent. In this work, I generalize some traits that help me ground my analysis of the context. However, many particularities are omitted due to the limits of this study.

The second part addresses a description of Miami-Dade County, which is the place where they arrive with their baggage. Particularly, two features of Miami are considered: Miami is the immigrant city chosen by thousands of South American 
millennials to reroot when migrating and, proportionately, is the most immigrant city of any major metropolitan area in the U.S. With around eighty percent of its population reporting affiliation to a religious tradition, Miami has a diverse and complex religious landscape.

\section{South American Millennials}

Millennials are a generational cohort of current young people who reached adulthood around the first two decades of the twenty-first century. They are generally characterized "by the use and adaptation of Information and Communication Technologies (ICT) in their daily lives, as well as values, life experiences, motivations, and common buying behaviors."

The term millennial is a sociological construct that defines a generational cohort. ${ }^{2}$ Generational cohorts are tools of analysis that researchers use to examine changes in views over time. They can provide a way to understand differences in cultural, economic, and social shifts, as well as in life-cycles, aging processes, generations' views, social practices, customs, feelings about a given issue, or identity processes. However, characterizing generational cohorts results in generalizations that might be questionable; hence, some scholars have misgivings about the use of this term. ${ }^{3}$ Beyond those debates,

\footnotetext{
${ }^{1}$ Flor Madrigal Moreno et al., "The Characterization of the Millennials and Their Buying Behavior," International Journal of Marketing Studies 9, no. 5 (2017): 135, DOI: 10.5539/ijms.v9n5p135

${ }^{2}$ William Strauss y Neil Howe, authors of the generation theory, are often credited to have coined the term millennial. This generational cohort has also been labeled as Generation Y, Echo Boomers, 'Don't Label Us' Generation, Generation Tech, Generation Next, Generation.com, Generation 2000, Echo Boom, and Boom Babies, among others.

${ }^{3}$ For example, Almudena Moreno, sociologist from Valladolid University, states that the term is useful for categorizing young people with market purposes, but it should not be used academically. She supports her
} 
there are some regularities that make the use of the term millennial meaningful as an analytical construct in the sense of a Weberian ideal type; that is to say, as a set of characteristics and associations of a given phenomenon that stresses certain elements and relations common to most cases, but is not meant to represent any specific ethnographic situation. ${ }^{4}$ Therefore, it must be made clear to the reader that delimitations, characteristics, and conclusions about these sociological constructs vary according to specific geographical, social, political, and economic features. Moreover, the identity features linked to millennials are consequences of global technological, sociological, and cultural phenomena. ${ }^{5}$

In this thesis, the term millennial is used interchangeably with youths or young people, among others. With this term, I am referring to the young population that shares some specific common features. Determining a cutoff point between millennials and the previous and following generations is an endless - and, from my perspective, absurddebate among scholars, especially in quantitative projects. ${ }^{6}$ Madrigal et al. synthesized

argument by explaining that they are a wide and heterogeneous group and they have such a quantity of differences that they cannot fall into one holistic category. She adds: "The young as such does not exist. There are many young people, who are influenced by many factors." In Antoni Gutiérrez-Rubí, Millennials en Latinoamérica: Una perspectiva desde Ecuador (Madrid: Fundación Telefónica, 2016), 5.

${ }^{4}$ Seth. D. Kunin, Religion: The Modern Theories (Baltimore and London: The Johns Hopkins University Press, 2003), 39.

${ }^{5}$ Gutiérrez-Rubí, Millennials en Latinoamérica, 104.

${ }^{6}$ Pew Research Center has recently determined the cutoff point between millennials and the next generation. Michael Dimock states:

Pew Research Center has been studying the Millennial generation for more than a decade. But by 2018, it became clear to us that it was time to determine a cutoff point between Millennials and the next generation. Turning 38 this year, the oldest Millennials are well into adulthood, and they first entered adulthood before today's youngest adults were born.

In order to keep the Millennial generation analytically meaningful, and to begin looking at what might be unique about the next cohort, the Pew Research Center decided a year ago to use 1996 as the last 
the proposal of many scientific articles about millennials birth periods. ${ }^{7}$ From this work, it can be concluded that the margins of the cohort go from 1977-1982 to 1996-2000. Based on these data, the interviewees in this thesis are young people from 20 to 39 years old.

In general, there are two main characteristics of why millennials are considered significant for research. On the one hand, they are the first digital natives because they have grown up with ICT within reach and have developed innate abilities in digital society. They use the Internet in most of their everyday life activities and, thus, ICT have evidently impacted their lives at many levels, such as education, spare time, social life, information, and religion. ${ }^{8}$

birth year for Millennials for our future work. Anyone born between 1981 and 1996 (ages 23 to 38 in 2019) is considered a Millennial, and anyone born from 1997 onward is part of a new generation. (In Michael Dimock, "Defining generations: Where Millennials end and Generation Z begins," Pew Research Center, accessed January 28, 2019, http://www.pewresearch.org/facttank/2019/01/17/where-millennials-end-and-generation-z-begins/)

These paragraphs need further considerations because some questions easily jeopardize the determination of such definitions when they are not contextualized. For example, is the difference between the people born in January 2017 and those born in December 2016 so meaningful? Does adulthood means the same and starts at the same age in the U.S., Brazil, Lebanon, Kenya, or Japan?

It is clear that for methodological designs, especially quantitative, researchers must made decisions. Otherwise, the data collection is impossible. However, it is necessary to maintain that these are methodological decisions that do not shape reality; on the contrary, they must help explain it. These considerations are important especially when polls are conducted worldwide with the same parameters.

For this thesis, the methodological decisions were also necessary. However, the understanding of South American millennials and their characteristics are not based only on the birth periods but on a wider set of features that make the concept methodologically valid and theoretically meaningful.

${ }^{7}$ Flor Madrigal Moreno et al., “The Characterization of the Millennials, 137.

${ }^{8}$ In Ernesto Fiocchetto, "Forty-Five Minutes of Intense Connectivity: Religious Identities in the Time of Information and Communications Technologies," for World Christianity, Urbanization, and Identity, Series World Christianity and Public Religion, vol. 3, eds. Moses Biney, Kenneth Ngwa, and Raimundo Barreto, (Fortress Press: Expected publication Fall 2019), I evolve on the consequences of ICT for religious identities and practices. 
On the other hand, they are the first labor force in the Americas and,

consequently, they are highly influential. They start to occupy positions of power and responsibility at economic, political, and social levels. Together with these status positions, the continuous and high sociability that they have confers them a massive influential power over the market and the demands of consumption.

Considering millennials only as ICT consumers and workers with particular characteristics is a bias that promotes a caricature of the youth. This is scientifically unacceptable and out of the purview of this work. In this vein, in order to achieve a better understanding of millennials, it is necessary to situate them in contexts that are broaderincluding other aspects rather than ICT, consumption, and labor-and sociologically more concrete-including socio-politico-economic dimensions. To this end, the next sections develop three particular aspects of millennials in South America that are relevant for this research; namely, the sociopolitical and economic context in which they grew up, the changes in the religious landscape that occurred in that period, and mobility and migration in the area.

\subsection{Socio-politico-economic Context: South American Millennials in the Times of}

\section{Neoliberalism and Post-Neoliberalism}

Unlike their parents who grew up among armed conflicts, dictatorships, and strong ideologies that shaped their social commitments and struggles, millennials have dealt with economic instability, democracy imperfections, and the fall of modern metanarratives. Large-scale changes occurred in the last decade of the twentieth century and 
the first decades of the twenty-first century in South America when they made their journey from childhood to youth.

Millennials' parents—also called Baby Boomers-lived the consequences of the overthrow of the democratic populist governments of the fifties. During the sixties and seventies, military dictatorships took power in most of the countries in the region. Those coups d'état have been a systematic strategy of U.S. authorities, who allied with the South American hegemonic powers, to intervene in the region. ${ }^{9}$ The experiences are profoundly different in each country. Being born after the Second World War, the millennials' parents lived the Cold War during their youth. Those moments of Grand Narratives led them to mobilize toward the acquisition of civil rights and to struggle against AntiImperialism in the region. The claim for the democratic order was another characteristic of this generation that suffered, in many countries of South America, the violation of their human rights by the dictatorships. They lived in times of torture, murder, and persecution for their ideas. It was the time of the Desaparecidos, student demonstrations, and social and political commitment. In the religious field, Liberation Theology gained strength throughout the whole subcontinent because it guided the actions of these young men and women who strove for great ideals and "opted for the poor" in their searches for social equality, justice, and regional independence. ${ }^{10}$

\footnotetext{
${ }_{9}^{9}$ Ana Maria Bidegain, "El Año 1968: desarrollos en sociedad, política e iglesia desde la perspectiva de la historia de la iglesia" (Paper presentation, Pontifical Catholic University of Peru, Lima, September 6, 2018).

${ }^{10}$ Ana Maria Bidegain, "El Contexto General que nos ayude a entender posturas y decisiones," in Obispos de la Patria Grande: Pastores, Profetas y Mártires, ed. Ana Maria Bidegain (Bogotá: Consejo Episcopal Latinoamericano: 2018), 17-36.
} 
The devastating consequences of the military governments continuously

challenged the stability of South America during the process recovering democracy in the decades of the eighties and nineties. Broadly speaking, the eighties left a critical juncture in the southern continent. Fragile democratic governments tried to consolidate the ongoing democratization process in the context of economic instability, which implied a severe slowdown of economic growth and consequent upsurge of poverty. ${ }^{11}$ The first part of the nineties saw a slight upsurge in economic growth and poverty reduction. However, the negative impact of the international crises in the last years of that period was relevant to the instability of the subcontinent. ${ }^{12}$ The improvements and setbacks concerning democracy consolidation and economic development, thus, are accounted for by exogenous and endogenous factors that have shaped complex processes that are difficult to generalize.

\footnotetext{
${ }^{11}$ Eduardo Gamarra, "Market-Oriented Reforms and Democratization in Latin America: Challenges of the 1990s," in Latin American Political Economy in the Age of Neoliberal Reform: Theoretical and comparative Perspectives for the 1990s, ed. William Smith, Carlos Acuña, and Eduardo Gamarra (New Brunswick and London: Transaction Publishers, 1994), 1-15.

${ }^{12}$ According to CEPAL, the relation between economic growth and poverty shows a clear asymmetry in the decades of the eighties and nineties in Latin America. During the eighties, the per capita product fell around $1 \%$ per year and poverty increased. During the nineties, however, the per capita product increased around $2 \%$ per year and poverty decreased. In fact, $40.5 \%$ of the population was poor in $1980,48.3 \%$ of the population was poor in 1990, and $43.8 \%$ was poor in 1999 . Therefore, the recovery during the 1990 s was partial compared against the 1980s. (It is important to clarify that the data include six countries of Central America and the Caribbean. However, the tendencies are similar in most of the countries so, for the purpose of this section, the numbers are highly representative of South America.)

Further evidence of the process and the particularities in some countries can be found in the following data. Brazil and Chile had the best performances in the region since poverty decreased more than $10 \%$ in both countries and the per capita product increased $1.2 \%$ and $2.6 \%$ per year respectively. Contrastingly, the number of poor people increased in Venezuela (34\% in 1990 to $44 \%$ in 1999). Ecuador, Colombia, and Paraguay had a positive tendency but did not register meaningful achievements during the decade. See: CEPAL, Una década de desarrollo en América Latina, 1990-1999 (Santiago de Chile: Naciones Unidas, 2004), 33-37. https://repositorio.cepal.org/bitstream/handle/11362/2382/S2004000_es.pdf;sequence=1
} 
During the nineties, the neoliberal model achieved its most extreme form in South America. After the failure of the orthodox adjustment program that started in 1982 due to the external debt crisis, the Washington Consensus, coined in 1989, was strictly applied by governments. Thus, South America entered the financial globalization driven by the monopolist-financial capital of the centers, especially the U.S., through international financial organizations like the International Monetary Fund and the World Bank. ${ }^{13}$ Presidents Carlos Menem in Argentina (1989-1999), Fernando Collor de Mello (19901992) and Fernando Henrique Cardoso (1995-2003) in Brazil, César Gaviria Trujillo (1990-1994) in Colombia, Patricio Aylwin Azócar (1990-1994) in Chile, and Rafael Caldera (1994-1999) in Venezuela are some of the Heads of State that led neoliberal policies under the rule of Washington Consensus. ${ }^{14}$

In the early nineties, the primary concern of many South Americans-especially the middle class - was to escape from the inflationary processes that corroded their income. To achieve that, they electorally supported governments that would be successful in stabilization processes. They did that with the hope of receiving, somehow sometime, part of the fruits of development. Adverse reactions came from some sectors that were

\footnotetext{
${ }^{13}$ Cristian Parker Gumucio, "Religión, cultura y política en América Latina: nuevos enfoques," in Religión, política y cultura en América Latina: Nuevas miradas, ed. Cristian Parker Gumucio (Santiago de Chile: Instituto de estudios Avanzados Universidad de Santiago de Chile and Asociación de Cientistas Sociales de la Religión del Mercosur, 2012), 22.

${ }^{14}$ For convenience of the reader, I will refer to the Plurinational State of Bolivia as "Bolivia," the Bolivarian Republic of Venezuela as "Venezuela," and the Oriental Republic of Uruguay as "Uruguay."
} 
affected by the privatization of state enterprises or the restrictions on public spending in some countries like Argentina. ${ }^{15}$

In contrast, by the end of the nineties, international financial crises, high debt burden, and stagnant growth provoked an expanded social discomfort. Such crises had a deeper impact since the interests of the politico-economic hegemonies in South America where linked to foreign capitals, especially form the U.S., and had shaped networks of corruption that led to an unequal distribution of wealth and economic slowdown. A public opinion poll conducted in those moments by the Economic Commission for Latin America and the Caribbean (ECLAC) reflects the uneasy situation. Sixty-seven percent of the respondents in 16 countries of the region considered that the distribution of wealth was unjust, and $61 \%$ considered that their country was not in the process of development. ${ }^{16}$

Generational differences in the perception of the South American situation were sharp. The economically active population — the millennials' parents - felt that they had less personal opportunities for growth than both the preceding and the following generation - the millennials themselves - , while younger generations - the first millennials - were disappointed by the difficulties they faced finding a job in light of their expectations. ${ }^{17}$

\footnotetext{
${ }^{15}$ CEPAL, Panorama Social de América Latina (Santiago de Chile: Naciones Unidas, 1995). https://www.cepal.org/es/publicaciones/1242-panorama-social-america-latina-1995

${ }^{16}$ CEPAL, Una década de desarrollo en América Latina, 1990-1999, 248.

${ }^{17}$ Ibid.
} 
The concern of the population with inequality also increased. The middle and lower classes thought that poverty and inequality levels seemed to be in contradiction with the achieved growth. They blamed the system dynamics and the politics of social actors with decision-making power for this contradiction, and they complained about the lack of action of the state apparatus. ${ }^{18}$ Therefore, South Americans turned very critical toward the empowered class, which produced an estrangement between citizenship and politics. This, compounded with the consequent discredit of professionalized politics led to the weakening of trust in political activity. At the base of such estrangement was the decrease of meta-narratives in the ideological spectrum, which will be addressed later.

The citizens' trust in institutions also weakened. Around $60 \%$ of the population did not trust in government institutions. Around $70 \%$ distrusted political parties, labor unions, and business associations. One of the institutions with the least level of mistrust was the Catholic Church with around 30\%. However, South Americans were interested in being well informed; the participation in presidential and parliamentary elections did not decrease; and many believed that voting could change things or could make things happen. ${ }^{19}$

The neoliberal policies of the nineties ended in devastating sociopolitical crises that produced the advancement of progressive, populist, and leftist political currents in the new millennium. Generally speaking, their political agendas were designed to break the premises of the Washington Consensus and recover the capacities of the states. The

\footnotetext{
${ }^{18}$ Ibid.

${ }^{19}$ Ibid., $249-250$
} 
idea of Post-Neoliberalism is a common factor of the different sociopolitical and economic new experiences in South America during the first and second decades of the twenty-first century. ${ }^{20}$

Post-Neoliberalism alludes to two articulated issues, namely, a model of development aiming economic growth with social redistribution and a sociopolitical matrix of inclusion that combines different democratic formats along the subcontinent. The construction of political and economic interregional blocks to mitigate the damaging effects of global integration promoted by Neoliberalism meant geopolitical strategies of leftist governments were developed in the milieu of regional organisms such as Unión de Naciones Suramericanas (UNASUR), Comunidad de Estados Latinoamericanos y Caribeños (CELAC), Banco del Sur, and Alianza Bolivariana para los Pueblos de Nuestra América (ALBA). However, the old anti-imperialist slogan did not promote a categorical rejection of capitalism; rather, it aimed to conform and reconfigure regional blocks to protect the national sovereignties in the face of new capitalist systems. ${ }^{21}$

On the one hand, these times imply evolution in human rights issues, solidification of democracy, protection of the rights of minorities - especially those around sexual minorities and gender issues - protectionist policies, economic growth, a better redistribution of wealth, political independence from the central powers-

\footnotetext{
${ }^{20}$ See John French, "Understanding the Politics of Latin America's Plural Lefts (Chavez/Lula): Social Democracy, Populism and Convergence on the Path to a Post-Neoliberal World," Third World Quarterly 30, no. 2 (2009), DOI : 10.1080/01436590802681090 and Arne Rückert, Laura Macdonald, and Arne Ruckert, Post-Neoliberalism in the Americas (New York: Palgrave Macmillan, 2009).

${ }^{21}$ Soledad Stoessel, "Giro a la izquierda en la América Latina del siglo XXI: Revisando los debates académcios," Polis Revista Latinoamericana 39 (2014): 8-9. http://polis.revues.org/10453
} 
particularly from the U.S., which after 9/11 has changed its focus to the Middle Eastand sturdy ideological constructions through new narratives. Furthermore, successful human rights policies and trials against members of the dictatorship found much support within South American societies. On the other hand, the extreme personalism of political leaders, high levels of corruption, populist bias, and the pressure of middle and high classes have jeopardized the new political juncture in the last years.

Some of the presidents of this South American sociopolitical structure in the first decades of the twenty-first century were Luiz Inácio Lula da Silva (2003-2011) and Dilma Rousseff (2011-2016) in Brazil, Nestor Kirchner (2003-2007) and Cristina Kirchner (2007-2015) in Argentina, Hugo Chávez (1999-2013) in Venezuela, Evo Morales (2006-present) in Bolivia, and Michelle Bachelet (2006-2010; 2014-2018) in Chile. The political projects they embodied suffered different fates: some of them are still alive; others have been defeated at the ballot boxes by new conservative governments; others have been challenged by important judicial processes of corruption.

\subsection{Religious Context: Changes in the South American Religious Landscape}

Quantitative studies on religion in South America in general and on religion and South American millennials, in particular, agree on some tendencies. ${ }^{22}$ First, South America presents a very high average of religiously affiliated people. In 9 out of 10 countries

\footnotetext{
${ }^{22}$ For this section, I have closely followed the result published by the Pew Research Center. However, I have compared them against other two opinion polls about religion and values in South America, namely Gallup Latinoamérica and LAPOP's El Barómetro de las Américas. After the comparison, I decided to work with the Pew Research Center publications because the differences among the three polls are minimum and non-significant for the goals of this thesis.
} 
surveyed by the Pew Research Center, the religious affiliation is around 90\%. ${ }^{23}{ }^{24}$ More than 425 million Catholics live in Latin America, and the Roman Catholic Church now has an American Latin pope for the first time in history. Yet identification with Catholicism has decreased in the entire region. ${ }^{25}$

Second, during the first half of the twentieth century around $90 \%$ of the population was Catholic. Today, the number has decreased to nearly $70 \%$. Overall, $84 \%$ of Latin American adults reported that they were raised Catholic, 15 percentage points more than those who currently identify as Catholic. ${ }^{26}$

Third, according to the Pew Research Center, in every South American country, the Catholic Church has experienced net losses from religious switching. The pattern is reversed among Protestants and people who do not identify with any religion. While the Catholic Church has lost adherents through religious switching, both Protestant churches and the religiously unaffiliated population in the region have gained members. Around $20 \%$ of the population in South America self-define as Protestant, and around $8 \%$ do not affiliate with any Church. ${ }^{27}$

\footnotetext{
${ }^{23}$ Pew Research Center, "The Age Gap in Religion around the World," June 12, 2018: 64-67. http://www.pewresearch.org/wp-content/uploads/sites/7/2016/03/Religion-and-Gender-Full-Report.pdf

${ }^{24}$ The exception is Uruguay. This country has a particular historical configuration that has conformed the country as less religious than the rest of South America. According to the Pew, the 63\% of the population are affiliated to a religion. The tendencies described in this section also apply to Uruguay but with different averages. (See Ibid.)

${ }^{25}$ Pew Research Center, "Religion in Latin America: Widespread Change in a historically Catholic Region," November 13, 2014: 4. http://www.pewresearch.org/wpcontent/uploads/sites/7/2014/11/Religion-in-Latin-America-11-12-PM-full-PDF.pdf

${ }^{26}$ Ibid.

${ }^{27}$ Ibid.: 4-5.
} 
Fourth, the Pew Research Center notes that the secularization process has affected the religious commitment of the affiliated population. The research center takes four standard measures of religious commitment, namely: affiliation, importance of religion, worship attendance, and frequency of prayer. In general, the values of the three latter categories are inferior to affiliation. For example, in Colombia 94\% of the population are affiliated with a religion, 50\% attend weekly to worship, $73 \%$ pray daily, and $77 \%$ consider that religion is very important in their lives. The most considerable divide is found in Venezuela, Brazil, Bolivia, Argentina, Peru, and Uruguay. For instance, in Argentina $89 \%$ of the population are affiliated with a religion, $20 \%$ attend weekly to worship, $40 \%$ pray daily, and $43 \%$ consider religion as very important in their lives. ${ }^{28}$ In general, the commitment among Catholics is lower compared to Protestants. ${ }^{29}$

Fifth, the age gap in religion shows two features of South American millennials. On the one hand, the total number of unaffiliated individuals is larger among adults under 40 years than among older adults. The South American millennials are less likely to identify with a religious group than older people are. This increasing number of the unaffiliated in the young population say they are atheists, or agnostics, or that their religion "is nothing in particular." On the other hand, the millennials affiliated with a particular religion are less religiously committed than previous generational cohorts. In all the cases, the four standard measures of religious commitment are notably lower for people aged less than 40 years. Table 1.1 shows both aspects of this tendency.

\footnotetext{
${ }^{28}$ Pew, "The Age Gap in Religion": 64-67.

${ }^{29}$ Pew, "Religion in Latin America":17.
} 
Table 1.1.: Type of religious commitment by South American country and age group (expressed as a percentage).

\begin{tabular}{|l|c|c|c|c|c|c|c|c|}
\hline \multirow{2}{*}{ CoUNTRY } & \multicolumn{4}{|c|}{ ADULTS $<40$} & \multicolumn{4}{c|}{ ADULTS 40+ } \\
\cline { 2 - 10 } & Affiliate & $\begin{array}{c}\text { Attend } \\
\text { Weekly }\end{array}$ & $\begin{array}{c}\text { Pray } \\
\text { Daily }\end{array}$ & $\begin{array}{c}\text { Very } \\
\text { Import. }\end{array}$ & Affiliate & $\begin{array}{c}\text { Attend } \\
\text { Weekly }\end{array}$ & $\begin{array}{c}\text { Pray } \\
\text { Daily }\end{array}$ & $\begin{array}{c}\text { Very } \\
\text { Import. }\end{array}$ \\
\hline Argentina & 86 & 15 & 31 & 35 & 92 & 25 & 48 & 51 \\
\hline Bolivia & 95 & 37 & 49 & 67 & 98 & 48 & 64 & 76 \\
\hline Brazil & 88 & 39 & 57 & 70 & 96 & 51 & 66 & 76 \\
\hline Chile & 77 & 14 & 29 & 29 & 90 & 24 & 46 & 50 \\
\hline Colombia & 93 & 41 & 66 & 71 & 96 & 60 & 81 & 83 \\
\hline Ecuador & 93 & 33 & 56 & 72 & 97 & 44 & 72 & 82 \\
\hline Paraguay & 98 & 31 & 76 & 48 & 99 & 34 & 89 & 64 \\
\hline Peru & 96 & 30 & 44 & 68 & 97 & 43 & 59 & 78 \\
\hline Uruguay & 52 & 10 & 18 & 22 & 70 & 16 & 36 & 33 \\
\hline Venezuela & 91 & 21 & 44 & 64 & 97 & 31 & 52 & 70 \\
\hline
\end{tabular}

Note: My elaboration based on Pew Research Center, "The Age Gap in Religion around the World," June 12, 2018: 64-67.

How can one explain this religious picture? Many South American researchers have given robust answers to this question. I will take some of the conclusions of two of them because their explanations are meaningful to the goals of this thesis.

Christian Parker Gumucio, a Chilean sociologist of religion, explains how the political and sociocultural transformations of the last decades implied the insertion of Latin American societies into global capitalism and transformed the religious landscape in a more pluralistic scenario. ${ }^{30}$ In the previous section, I claimed that at the base of the estrangement between citizenship and politics in South America, there is a decrease of

\footnotetext{
${ }^{30}$ Parker Gumucio, "Religión, cultura y política en América Latina": 14.
} 
meta-narratives in the ideological spectrum. Parker asserts that the fall of socialism terminated the polarization of the Cold War, and consequently, the distinction of political parties that searched for freedom promoted by capitalism and those that searched for justice promoted by socialism. In turn, this process entailed the so-called "crisis of utopias," which resulted in Late Modernity and the declaration of the "end of ideologies." 31

Such a crisis of ideologies profoundly influenced Christianity in South America. The affirmation of religious beliefs is not the exclusive property of conservative sectors anymore, nor is atheism inevitably associated with left-wing factions. On the one hand, the Catholic movements and political parties inspired by Liberation Theology had divergent trajectories. Ecclesial groups were affected by the conservative shift of the Catholic Church hierarchy, the growth of protestant options, and the new local social movements. Indeed, many leaders of the Church of the poor emigrated to progressive governments and non-religiously affiliated NGOs. On the other hand, the conservative Christian field is also more pluralistic. Many spiritual movements struggling for positions within Christianity arose. For example, the Opus Dei and several apocalyptical and abstentionist Protestant and Evangelical movements gained ground politically. The conservative Pentecostal field politically fractioned. The conservative Christian sector in South America is no longer a united front. Even if they achieve temporary political agreement on morals issues like abortion or same-sex marriage, they have a less

\footnotetext{
${ }^{31}$ Ibid.: 20-23.
} 
consistent and lasting impact in the political scenario. ${ }^{32}$ In brief, the fall of the metanarratives in the religious South American field resulted in a diffuse, diverse, and pluralistic landscape in which right wing or left wing was no longer a classificatory axis to differentiate Christians and non believers in politics.

The consolidation of democracies and the post-neoliberal governments at the beginning of this century accentuated the process of religious pluralization. The new South American left is not anti-religious, and indeed, supported religious leaders, values, and symbols. Thus, Hugo Chavez declared his Christian faith several times. Dilma Rousseff, who came from the Marxist Revolutionary Organization Política Operária joined the Liberation-Theology-inspired Partido dos Trabalhadores in 2001. When she faced the presidential elections in 2010, her public image was linked to anti-religious positions. As an electoral strategy, she purposefully avoided the legalization of abortion and showed herself committed to Christian rituals and values. Fernando Lugo was an exbishop who professed Liberation Theology and became President of Paraguay. Michelle Bachelet—declared agnostic—and Cristina Kirchner—declared Catholic—supported similar progressive political views, especially in sexual and family rights. ${ }^{33}$

To sum up, the time when millennials were children and teenagers was a moment of significant changes in the South American Christian landscape. Such changes occurred in a field with a large Catholic — and therefore Christian — tradition that started from colonization and strongly influenced societies in the southern continent. Some Latin

\footnotetext{
${ }^{32}$ Ibid. 16-20.

${ }^{33}$ Ibid.: 23-26.
} 
American scholars described Catholicism as a habitus that equally shapes the religious experience of Catholics, non-Catholic Christians, people affiliated to other religions, and non-religious people. ${ }^{34}$ Over this Catholic matrix, millennials witnessed the emergence of Christian forms with fluid boundaries as a result of the fall of meta-narratives and the consequent estrangement between citizenship and politics in South America.

Fortunato Mallimaci, an Argentine sociologist of religion, offers a theoretical framework that is complementary to Parker's. His vast research on religious phenomena in Argentina and South America makes him an authority in the field. Following the French sociologist Hervieu-Leger, who will be addressed in the following chapter, Mallimaci explains some trends and features that are meaningful to my work. Based on a high number of robust quantitative and qualitative research, he claims that similar processes shape religions in South America beyond the regional differences and particularities.

First, he describes a process of deep individualization of religious experiences. Believers configure their own religious itineraries and appropriate beliefs from different religious markets. They individually structure "custom-made" small universes of meanings which are constructed in accordance with their material, spiritual, and symbolic needs. ${ }^{35}$

\footnotetext{
${ }^{34}$ Pierre Sanchis, "Catolicismo, entre tradição e modernidades," Comunicações do ISER 44 (1993): 9-17 quoted in Alejandro Frigerio, "Repensando el monopolio religioso del catolicismo en la Argentina" in Ciencias sociales y religión en América Latina: perspectivas en debate, ed. Maria Julia Carozzi and Cesar Ceriani Cernadas (Buenos Aires: Biblos, 2007), 113.

${ }^{35}$ Fortunato Mallimaci, "Cuentapropismo religioso: creer sin ataduras. El nuevo mapa religioso en la Argentina Urbana," in Religión, política y sociedad: Pujas y transformaciones en la historia argentina reciente, ed. Aldo Ameigeiras and José Pablo Martín (Buenos Aires: Prometeo Libros, 2008): 15-43.
} 
Second, new modes of belief emerge with different levels of independence of the religious institutions. There is an increasing incapacity of such institutions to propose significant interpretative frameworks and regulate believers' everyday lives. Such incapacity results in deinstitutionalized religious experiences that go from "believing without belonging"- people who keep faith out of the boundaries of a religious institution - to "belonging without believing" - those who self-affiliate into a religious tradition but distance themselves of the teaching or normative of the religious institution. ${ }^{36}$

Third, because of the two previous features, the believers are pilgrims and migrants in constant religious circulation. Shaped by a strong Christian culture, the believers do not stay in a predetermined religious form. Deep processes of affiliation and disaffiliation occur that challenge the links between individuals and religious institutions. This is possible because of the increasing possibilities of the religious market and the reduction of the social cost of self-defining as atheist, agnostic, or believer. ${ }^{37}$

Fourth, because of the religious circulation of believers, religious experiences turn diffuse. Believers make and re-make their own meanings by reading, listening, or taking part in diverse manifestations of different religious groups or institutions. The small

\footnotetext{
${ }^{36}$ Fortunato Mallimaci y Verónica Giménez Béliveau, “Creencias e increencia en el Cono Sur de América: Entre la religiosidad difusa, la pluralización del campo religioso y las relaciones con lo público y lo político, Revista Argentina de Sociología 5, no. 9 (2007): 44-63. http://www.scielo.org.ar/pdf/ras/v5n9/v5n9a04.pdf

${ }^{37}$ Ibid.
} 
system of beliefs they create is diverse, complex, and hybrid since it is composed of multiple beliefs from varied traditions. ${ }^{38}$

\subsection{Migratory Context: Mobility and Migration in Millennials'South America}

According to the International Organization for Migration (IOM), which is the United Nations Migration Agency, South America is a region of origin, destination, and transit of international migrants. Since the beginning of the twenty-first century, population movement in the southern continent has demonstrated variations in direction, intensity, and composition. Simultaneous flows of emigrants, immigrants, and refugees or asylum seekers have been observed within the region. ${ }^{39}$

The following traits stand out for mobility patterns in South America. Intraregional cross border migration has intensified; there has been a growth and diversification of countries of origin and the destination of extra-regional immigration; and extra-regional emigration persists as a trend. Some quantitative data depict the third trait, which is meaningful for our research. South America has over 10 million emigrants and the regional average for emigration stands at $5.4 \%$ of the total population. ${ }^{40}$ Further analysis of each country results in different trends. Only Argentina (4.4\% of the total population), Venezuela (4.2\%), and Suriname (7.5\%) have a positive migratory balance.

\footnotetext{
${ }^{38}$ Fortunato Mallimaci, "Creer por su propia cuenta en la ciudad de Buenas Aires en el siglo XXI," in Guía de la diversidad religiosa de Buenos Aires. Vol 2, ed. Floreal Forni, Fortunato Mallimaci and Luis Cárdenas (Buenos Aires: Biblos, 2008), 15-31.

${ }^{39}$ IOM, “South American Migration Report N. I - 2017,” June, 2017: 1. http://robuenosaires.iom.int/sites/default/files/Documentos\%20PDFs/Report_Migration_Trends_South_Am erica_N1_EN.pdf

${ }^{40}$ Ibid.
} 
In absolute terms, the countries with the largest population living abroad are Colombia (more than 2.5 million people), Ecuador $(995,000)$, and Peru $(981,000)$. In relative terms, the countries with the greatest proportional number of emigrants are Guyana (49.7\%), Paraguay (11.1\%), Uruguay (7.2\%), Bolivia (6.9\%), and Ecuador (6.7\%). From 2000 onwards, the majority of the countries experienced an increasing number of emigrants. The exceptions are Chile and Uruguay because they achieved political stability and economic growth, and in Uruguay, there is a population aging process that undermines its potential for emigrations. ${ }^{41}$

Venezuela has specific characteristics. Although it is the second country with a positive migratory balance, it registered an outstanding growth of emigrations. The political and economic crisis that affects the country as a result of the Nicolas Maduro government has intensified the emigration of individuals to foreign countries. From 2014 onwards, 2.3 million Venezuelans have left their country. Most of the members of Latin America's most massive exodus flee to locations elsewhere in the region, in particular, Colombia, Argentina, Chile, Ecuador, and Peru. ${ }^{42}$ Others decide to move out of the region. The two most popular destinations for them are the U.S. and Spain.

The emigration of South Americans is related to the socio-politico-economic models described in the first section of this chapter. Neoliberal and post-neoliberal

\footnotetext{
${ }^{41}$ CEPAL, "Panorama de la migración internacional en América del Sur," Executive Report of the Reunión regional latinoamericana y caribeña de expertas y expertos en migración internacional preparatoria del Pacto mundial para una migración segura, ordenada y regular, Santiago de Chile, August, 2017: 3-4. https://refugeesmigrants.un.org/sites/default/files/eclac_america_del_sur_resumen_ejecutivo.pdf

${ }^{42}$ Jie Zong and Janne Batalova, "South American Immigrants in the United States," Migration Information Source (November, 2018), https://www.migrationpolicy.org/article/south-american-immigrants-unitedstates/
} 
policies have favored processes of social impoverishment and increasing social vulnerability in particular economic sectors. A second reason is the economic and political crises that the countries faced in particular moments of their history and produced increasing emigration in short periods. The current Venezuelan crisis and the Argentine crisis in 2001 are good examples of this tendency.

Therefore, the reasons for emigration of South Americans are, almost exclusively, related to work and the search for better living conditions. Political pressures and persecutions are other of the reasons claimed by emigrants. Consequently, emigration from South America to other areas of the world, particularly the global north, in the last three decades has been composed mainly of middle-class individuals, with a significant component of qualification. For instance, the average years of education of South American migrants to the global north is superior to the average of people with the same education level in the countries of origin. ${ }^{43}$ Another characteristic of these South American migrants is the sustained increase of migrant women who challenge the traditional roles assigned to women in migratory contexts, such as companion, dependent, daughters or wives. ${ }^{44}$

Of the 12 million South Americans residing outside of their country of birth, more than 4 million live in other countries of South America. Outside the region, the most popular destinations in terms of the quantitative importance of South American emigration are the U.S. and Spain. The U.S. is by far the main host of South American

\footnotetext{
${ }^{43}$ CEPAL. "Panorama de la migración internacional en América del Sur": 11.

${ }^{44}$ Ibid.: 10.
} 
migrants with almost 3 million individuals, followed by Spain with 1.8 million. ${ }^{45}$ Colombia, Peru, and Ecuador are the most numerous population groups that flee to the U.S. totaling more than 1.5 million. Nearly a quarter of the total South American migrants were born in Colombia. Paraguayan, Venezuelan, and Brazilian populations grew in the country. Paraguayans almost tripled their number and Brazilians grew by 2,000 emigrants to stand at $361,374 .{ }^{46}$ The number of Venezuelans who emigrated to the U.S. has considerably risen from 216,000 in 2014 to 351,000 in 2017 , with a growth of 61,000 in one year alone, from 2016 to $2017 .{ }^{47}$

These characteristics of migration in South America, which are very different from the features of migration in Latin America and the Caribbean and remain understudied, directly affect millennial migrants from that region. ${ }^{48}$ Most of them migrated with their families when they were children or teenagers due to neoliberal processes and the subsequent economic crises in the south. After 2000, they have migrated as young adults in search of education, work, and better living conditions, in many cases leaving their households. The quantitative differences regarding gender are not significant. In general, they belonged to middle-class sectors in their countries of origin. Therefore, they arrived at the host country with a good level of education, acceptable proficiency in

\footnotetext{
45 Zong and Batalova, "South American Immigrants in the United States."

${ }^{46}$ IOM, "South American Migration Report N. I": 7.

${ }^{47}$ Zong and Batalova, "South American Immigrants in the United States."

${ }^{48}$ Ana Maria Bidegain, ed., Presencia Colombiana En Estados Unidos: Caracterización de La Población Inmigrante (Bogota: Imprenta Nacional de Colombia, 2008) is an excellent effort to characterize Colombian immigrants in the U.S. Studies on this matter are scarce.
} 
English, and high expectations for economic progress with the corresponding will to work and the required qualifications to make personal or familiar progress possible.

The preference for the U.S. as the most popular destination for South American migrants outside the region is logical in the historical context described. During the nineties, the U.S. was presented in the region as the victorious power of the Cold War, the most developed country of the world, and the model to follow. The hegemony of the northern country translated the political and economic power represented in the Consensus of Washington into a cultural and ideological hybridization in South America. The incorporation of the region in the global market led by the U.S. turned the subcontinent into a demanding symbolic market of American goods and lifestyles. The hegemonic politico-economic sectors and the public figures of the south were the model consumers and promoters of the American dream, which was a very effective ideological construct in South America.

During the Post-Neoliberalist period, admiration for the U.S. disappeared in the political sectors that governed the region. Indeed, a rejection of the northern country policies and interventions was part of the agenda of the new left parties. However, feelings toward the U.S. remained ambivalent in the region. A significant proportion of the population subscribed to such discourses based on the harmful activity of the northern country in South America. Those who suffered the negative consequences of these governments kept the ideal of the U.S. as the perfect nation that offered all the benefits of capitalism, progress, and technology. In contrast to the anti-U.S. narratives of the regional hegemonies, this country was the dream option for many emigrants. 
In both periods, Miami was one of the most popular destinations for South Americans since it embodied the idealized desires of migrants: economic progress, beautiful landscapes, high standards of living, and a Latino context that would allow immigrants to feel at home easily. In the popular South American imagination, Miami is a paradise of sun, beaches, parties, success, and chances for a good life.

\section{South American Migrants and Believers in Miami}

\subsection{South American Migrants in the U.S.: some traits}

South American millennials who arrive in the U.S. both share the sociodemographic characteristics of the overall immigrant population and mirror the characteristics of their region of origin. According to quantitative studies, they are slightly more educated, more willing to participate in the labor force, and have higher household incomes that the overall immigrant population. ${ }^{49}$ The following are some features of South American migrants in the U.S.

On average, most South American millennial immigrants obtain lawful permanent residence in the country — green card — through family ties. They are more likely to be naturalized U.S. citizens than immigrants are overall. To be sure, in 2017, 53\% of South Americans had taken U.S. citizenship, compared to $49 \%$ of the total foreign-born population.

South American immigrants aged 25 and older are much more likely to have graduated from high school than the rest of the migrants. In 2017, $15 \%$ of South

${ }^{49}$ Ibid. 
Americans had not finished high school, compared to $28 \%$ of all immigrants and $9 \%$ of U.S.-born adults. Approximately $32 \%$ of South American adults had a bachelor's degree or higher. The figure is the same for native-born adults. Venezuelans, Chileans, Argentines, and Brazilians have the most college-graduate proportion among immigrants from South America. ${ }^{50}$

In 2017, South American immigrants had the same median age as the overall foreign-born population ( 45 years) but were much older than the U.S.-born population (36 years). Eighty percent of South American immigrants are working age (18 to 64). South Americans participate in the labor force at a higher rate than both the U.S.- and overall foreign-born populations. Seventy percent of South American immigrants ages 18 and over were in the labor market in 2017, compared to $66 \%$ of all immigrants and $63 \%$ of the U.S.-born. Owing to their higher levels of college education and better English skills, a significant share of immigrant workers from Argentina (46\%), Venezuela (42\%), Chile (38\%), and Brazil (36\%) worked in management, business, science, and arts occupations. $^{51}$

The average household income of South Americans falls between overall foreignand native-born populations. In 2017, households headed by a South American immigrant had a median income of $\$ 58,600$, compared to $\$ 56,700$ for all immigrants and $\$ 60,800$ for U.S.-born households. The highest median incomes fall in households

\footnotetext{
${ }^{50}$ Ibid.

${ }^{51}$ Ibid.
} 
headed by Argentines $(\$ 66,800)$, Bolivians $(\$ 64,200)$, and Brazilians $(\$ 61,700)$, while Venezuelan $(\$ 51,900)$ households had the lowest median incomes.

Regarding poverty, the rate of South Americans families that lived in poverty (11\%) was lower than foreign-born families overall (14\%). However, this rate was slightly higher than native-born families (9\%). Out of all South American immigrants, Venezuelans (18\%) are in the worst conditions related to poverty, followed by Chileans (12\%). In contrast, only $5 \%$ of immigrant families from Argentina were below poverty. ${ }^{52}$

Remittances sent to South America have grown since the late nineties. In 2017, global remittances sent via formal channels to the region equaled $\$ 17.8$ billion, up 9\% from 2016. Three countries received two-thirds of such remittances: Colombia received $\$ 5.6$ billion (32\%), followed by Peru with $\$ 3$ billion (17\%) and Ecuador with $\$ 2.8$ billion $(16 \%) .{ }^{53}$

\subsection{Miami, an Immigrant City Chosen by South American Millennials}

From 2012 to 2016 most immigrants from South America lived in Florida (25\%), New York (20\%), or New Jersey (11\%). Miami-Dade County in Florida, Queens County in New York, Broward County in Florida, Los Angeles County in California, and Kings County in New York were the five counties with the most South Americans. Thus, more

\footnotetext{
${ }^{52}$ Ibid.

${ }^{53}$ Ibid. It is important to clarify that there are no official data about remittances to Venezuela.
} 
than $50 \%$ of South American immigrants lived in three metropolitan areas, namely, New York, Miami, and Washington, DC. ${ }^{54}$

According to the U.S. Census Bureau, the estimation of South American migrants in Miami-Dade County is over $10 \%$ of the population, that is to say, more than 250,000 individuals. ${ }^{55}$ With more than $50 \%$ of its population having been born in other countries and more than $80 \%$ having foreign-born parents, Miami is proportionately the most immigrant city of any major metropolitan area in the U.S. In the words of Stepick, Rey, and Mahler, "Miami is the quintessential new immigrant city." 56

The beginning of a significant Latino migration wave into Miami dates from the 1959 Cuban Revolution. After six decades, migration saw a dramatic, rapid transformation in the city at all levels: its culture, economy, and politics are shaped by this feature. "Local politics are dominated by foreign-born immigrants and their offspring. For the first time in American history, a group of first-generation immigrants has assumed control of local political institutions and risen to the top of the local socioeconomic hierarchy." 57

\footnotetext{
${ }^{54}$ Jie Zong and Janne Batalova, "South American Immigrants in the United States," Migration Information Source (November, 2018). https://www.migrationpolicy.org/article/south-american-immigrants-unitedstates/

${ }^{55}$ United States Census Bureau, "QuickFacts: Miami-Dade County, Florida," accessed January 14, 2019, https://www.census.gov/quickfacts/fact/table/miamidadecountyflorida/PST045218\#

${ }^{56}$ Alex Stepick, Terry Rey, and Sarah J. Mahler, eds., Churches and Charity in the Immigrant City: Religion, Immigration, and Civic Engagement in Miami. (New Brunswick, New Jersey: Rutgers University Press, 2009), 17.

${ }^{57}$ Ibid.
} 
Miami is a cultural and ethnical melting pot. According to the estimations for 2017 by the U.S. Census Bureau ${ }^{58}$, the racial/ethnic breakdown of Miami is:

- White: $78.6 \%$

- Black or African American: $18.2 \%$

- American Indian and Alaska Native: 0.3\%

- Asian: $1.6 \%$

- Native Hawaiian and Other Pacific Islander: 0,2\%

- Two or More Races: $1.2 \%$

- Hispanic or Latino: $68.6 \%$

- White, not Hispanic or Latino: $13.2 \%$

Another important feature of this multicultural city is the languages that are spoken in its territory. Twenty-three percent of Miami residents speak only English, while $76.96 \%$ speak other languages. The largest non-English language is Spanish, which is spoken by $69.96 \%$ of the population. ${ }^{59}$ The high number of Spanish speakers and Latino presence are two main features that made Miami-Dade County a preferred option by South Americans.

Miami's median age is 40 years old (39.1 for male; 40.1 for women). Analyzing the Census estimations for 2017, millennials in Miami-Dade County constitute 751,857 people (29.7\% of the total population), and around $50 \%$ of the labor force of the area.

\footnotetext{
${ }^{58}$ United States Census Bureau, “QuickFacts: Miami-Dade County, Florida.”

${ }^{59}$ World Population Review, “Miami, Florida Population 2019: Demographics, Maps, Graphs,” accessed January 14, 2019, http://worldpopulationreview.com/us-cities/miami-population/
} 
The total of millennials is divided into 379,009 male and 372,848 female. ${ }^{60}$ These numbers made millennials the current most important sector of this young city.

Cross-matching data from this section, one can clearly conclude that the importance of Hispanic millennials, which include South American millennials, is crucial in the life of Miami-Dade County, as it is in some other cities of the U.S. So much so that the new term "Hispennial" has recently appeared in newspapers, magazines, and blogs to name the active generation that seems to be powerful enough to change the U.S. economy. ${ }^{61}$

\subsection{Miami, a Migrant Metropolis with a Diverse Religious Landscape}

With around $80 \%$ of its population reporting affiliation to a religious tradition, this migrant and young metropolis has a diverse religious landscape. Being one of the most immigrant cities of the U.S., the impact of immigration is also visible and profound regarding religions. Stepick, Rey, and Mahler note: "Nowhere else has an overwhelmingly mainstream Protestant religious community, with a significant Jewish presence, been so altered by the rapid rise of the Catholic Church, by Evangelical Christians who were missionized by Americans before immigrating to Miami, and by a substantial infusion of Afro-Caribbean religious traditions. Moreover, Miami contains

\footnotetext{
${ }^{60}$ United States Census Bureau, “American FactFinder: Age and Sex 2013-2017 American Community Survey 5-Year Estimates,” accessed January 14, 2019. https://factfinder.census.gov/faces/tableservices/jsf/pages/productview.xhtml?pid=ACS_17_5YR_S0101\& prodType=table

${ }^{61}$ Further example of the use of this term can be found in articles and blogs, like the following: - https://www.bbc.com/mundo/noticias-45957047;

- http://blog.globalizationpartners.com/reaching-the-hispennial-market.aspx;

- http://hispennials.com/
} 
contrasts between immigrants who are White and Black, rich and poor, politically powerful and disempowered, those highly connected to religious institutions and those disconnected from churches, Christian and Afro-Caribbean." 62

The U.S. Religious Landscape Survey, conducted by the Pew Research Center, offers relevant data about religion in the Miami Metro Area. ${ }^{63}$ Some data that are meaningful for this thesis are pointed out below. First, $79 \%$ of the population in the Miami Metro Area self-affiliates with a religious tradition. The rest of the population remains unaffiliated. They are the $21 \%$, which include $3 \%$ of atheist, $3 \%$ of agnostic, and a wide number of people of around $15 \%$ who fall in the category of "Nothing in Particular."

Second, from those who are affiliated, Christianity is by far the religion that has the most people. Sixty-eight percent of the individuals who live in the Miami Metro Area are Christians, including 27\% of Catholics, and $20 \%$ of Evangelical Protestant over the total of the population. The rest are other Christian denominations. Non-Christian faiths are $10 \%$ of the total population. The most important group among them is Jews, who represent $9 \%$ of the total population. The remaining percentage point includes Muslims, Buddhists, Hindus, other World Religions, and other faiths. In conclusion, the diverse religious landscape in Miami is formed over a Christian matrix with an important number of Catholics. The migratory effects of the high number of Catholic Latin American migrants over this landscape are obvious.

\footnotetext{
${ }^{62}$ Stepick, Rey, and Mahler, eds., Churches and Charity in the Immigrant City, 19.

${ }^{63}$ Pew Research Center, "Religion \& Public Life: Adults in the Miami Metro Area," accessed January 4, 2019, http://www.pewforum.org/religious-landscape-study/metro-area/miami-metro-area/
} 
Third, the Miami Metro Area has similar religious trends as the ones in South America previously analyzed in this chapter. Sixty-one percent of the population are absolutely certain of their beliefs in God; $57 \%$ claim that religion is very important in their lives; 37\% attend religious services at least once a week; 57\% pray at least daily; $27 \%$ participate in prayer, scripture study or religious education groups at least once a week; for $29 \%$ of the population, religion is a source of guidance on right and wrong. Therefore, we can apply to Miami the processes described by Mallimaci. In Miami, people individualized their beliefs and religions are immersed in processes of deinstitutionalization and circulation as their boundaries turn diffuse.

Fourth, millennials are the least overtly religious American generation in modern times because, for example, one-in-four of the individuals aging 18 to 29 are unaffiliated with any particular faith. Yet not belonging does not necessarily mean not believing. Millennials pray about as often as their elders did in their own youth. ${ }^{64}$ Fewer young adults belong to any particular faith than older people do today. They are also less likely to be affiliated than previous generations were when they were young. Millennials also attend religious services less often than older Americans. Compared against their elders today, fewer young people say that religion is very important in their lives. Yet in other ways, millennials remain fairly traditional in their religious beliefs and practices. For instance, the number of young adults who say they pray every day rivals the portion of young people who said the same in prior decades. Moreover, though belief in God is

\footnotetext{
${ }^{64}$ Pew Research Center, "Millennials: Confident. Connected. Open to Change," February, 2010: 2, http://www.pewresearch.org/wp-content/uploads/sites/3/2010/10/millennials-confident-connected-open-tochange.pdf
} 
lower among young adults, millennials say they believe in God with absolute certainty at rates similar to those seen among the previous generation. ${ }^{65}$

At this point, there are some data that turn the landscape more complex. As discussed earlier in this chapter, the Pew Research Center takes four standard measures of religious commitment, namely affiliation, importance of religion, worship attendance, and frequency of prayer. Most of the qualitative studies do the same. These standard measures are used to determine the processes of religious deinstitutionalization. The picture seems to be logical and coherent, but if we analyze further the quantitative data at hand, we can highlight some apparently contradictory data with the hope to find some answers at the end of this research.

There are individuals in Miami who believe in God and are not affiliated with a religious tradition. If we add the individuals who are absolutely certain to believe in God $(61 \%)$, plus those who are fairly certain (20\%), plus those who are not at all certain $(6 \%)$, we can affirm that $87 \%$ of the population in Miami Metro Area somehow believe in God, while only $79 \%$ are affiliated to a religion. ${ }^{66}$ A cursory reading of this statement could make it appear that there is no contradiction in both affirmations, and indeed, there is not. One can believe in God without an affiliation. However, they show a mode of believing outside the boundaries of a religious affiliation exists, and needs to be addressed. These believers challenge, for example, our understanding of the link between religion, selfaffiliation, and beliefs.

\footnotetext{
${ }^{65}$ Ibid.: 85-86.

${ }^{66}$ Pew Research Center, "Religion \& Public Life: Adults in the Miami Metro Area."
} 
There are individuals who do not believe in God but are affiliated with a religious tradition. If we go one step further and we analyze the variables per religion in the U.S., we can observe surprising data ${ }^{67}$ Two percent of Catholics, $1 \%$ of Evangelical Protestant, 3\% of Orthodox Christians, for example, do not believe in God.

On the other side of that same coin, there are individuals in Miami who perform religious practices that seem to signify religious institutions, but they are not affiliated with a religious tradition. Following the national trends, around $4 \%$ of the unaffiliated attend religious services at least once a week, and $24 \%$ of the same group attend from once or twice a month to a few times a year. More simply put, there are individuals who attend at worship — mass, for example — every single week, but they do not self-identify with the religious tradition-Catholicism, for example.

Praying as a sign of religious commitment is also challenged. At a national level, $38 \%$ of the unaffiliated pray at least monthly and $13 \%$ of the individuals who self-define as Catholics seldom or never pray. The figure for the Evangelical Protestants who seldom or never pray is $4 \%$ and $15 \%$ for the Orthodox Christians.

The baggage these migrants bring is complex. The city where they bring such baggage is complex as well. Easy answers to such complexities tend to be essentialist, biased, or functional to non-scientific purposes. The next chapter of this thesis offers a theoretical background on religion and identities in order to return to factual data-no

\footnotetext{
${ }^{67}$ This analysis is made on the base of the total population of the country because the disaggregated data for Miami Metro Area is not offered in the digital platform. It is a well-founded assumption that this data repeats in Miami. All the data at a national level was obtained from: Pew Research Center, "Religion \& Public Live: Religious Landscape Study," accessed January 4, 2019, http://www.pewforum.org/religiouslandscape-study/
} 
longer from a quantitative perspective, but from a qualitative one-in the third chapter and, thus, avoid the lure of easy answers. 


\section{CHAPTER 2: Religious Identities in Late Modernity}

In the first chapter, I addressed several particular aspects of the context of this work. However, if I want to be consistent with the purpose of grounded research that I pursue, it is insufficient to finish the description of such ground with a general view of the subject population of this research and the general geopolitical aspects of Miami as an immigrant and religious city. Rather, this work must also be grounded in the theoretical approaches to the broader social processes in which the social facts that this thesis addresses can be better understood. Therefore, this chapter tackles the nuclear concepts of this researchnamely religion and identity - in the general context of Late Modernity.

The processes of the configuration of religious identities in Modernity are not unilineal. The modern concept of secularization, as the withering away of religion in Western societies — as the most classical modern thesis asserted — seems to be the common, but simplistic, interpretation for many religious scholars. In fact, if instead of understanding this concept in this way, we comprehend secularization as the readjustment of the beliefs within societies, the landscape of religious Modernity turns vast, plural, and hybrid. Consequently, the intent to build a great theory that helps us understand Modernity and religious Modernity is challenging. Nevertheless, some authors have produced robust frameworks that can lead us to a better understanding of religious identities in Western Societies. 


\section{Towards an Understanding of Late Modernity: Three Main Contributions}

There are many reasons to assert that Anthony Giddens, Ulrich Beck, and Zygmunt

Bauman's approaches to Modernity have dominated sociological theory and imagination

from the end of the twentieth century until now. Some of these reasons are the wide range of relevant and current issues they have addressed, the implications of their theories in contemporary politics and economy, the weight they have in the academy worldwide, and the public projection of their thought. Although their works diverge in many aspects, they agree that there has not been a radical break from Modernity, but instead an adjustment of the modern project. Moreover, they agree that one of the main characteristics of Modernity in the period that started in the second half of the twentieth century, which Giddens names Late Modernity, ${ }^{1}$ Ulrich Beck as Second Modernity, ${ }^{2}$ and Zygmunt Bauman as Liquid Modernity, ${ }^{3}$ is that the dynamics of capital is the decisive cause of the highly developed globalized societies in the West. Moreover, they highlight that all the dimensions of Late Modernity, including religion and identity, are to be understood as shaped by the engine of capitalism.

Thus, the context of such societies is the socioeconomic transformation of capital that allowed, from the beginning of the 1960s, the path from industrial to postindustrial society, from a solid to a liquid Modernity, from a producing to a consuming society. ${ }^{4}$

\footnotetext{
${ }^{1}$ Anthony Giddens, Modernity and Self-Identity: Self and Society in the Late Modern Age (California: Stanford University Press, 1991).

${ }^{2}$ Ulrich Beck, Risk Society: towards a new Modernity (California: Sage Publications, 1992).

${ }^{3}$ Zygmunt Bauman, Liquid Modernity (Cambridge: Polity Press; Massachusetts: Blackwell, 2000).

${ }^{4}$ In Ernesto Fiocchetto, "Forty-Five Minutes of Intense Connectivity: Religious Identities in the Time of Information and Communications Technologies," for World Christianity, Urbanization, and Identity, Series World Christianity and Public Religion, vol. 3, eds. Moses Biney, Kenneth Ngwa, and Raimundo Barreto,
} 
These processes imply the path from a Fordist, industrial, disciplinary, and rigid capitalist system to a service, flexible, immaterial, and light system that exerts power through subtle forms of control. In these scenarios, a dialectic between the global and the local appears, and it challenges traditional frameworks such as the heteronormative family, powerful institutional leaders - including the religious and political ones — and schooling as the unique transmitter of knowledge. Therefore, this dialectic results in uncertainty, fragility, instability, and doubt, which are symptomatic of our contemporary reality. ${ }^{5}$ The experienced caducity of the industrial society through the risks and uncertainties at social, political, economic, and individual levels tends to discredit the institutions of control and protection that seem to have failed in their goals. Moreover, this risk society has the adaptation mechanism required by capital for its evolution within itself. To paraphrase David Harvey, Modernity was constructed under the model of an expected stability granted by the ideals of nation-state and economic development. In contrast, Postmodernity brought a change from stability to permanent mobility, flexibility, and ephemerality. ${ }^{6}$ The consequences of this model are that societies turn diffuse- - with no

(Fortress Press: Expected publication Fall 2019), I develop a better detailed explanation of the said path in relation to the configuration of Christian identities and the influence of the new information and communication technologies. The next two paragraphs are based on this essay.

${ }^{5}$ In Ulrich Beck and Elisabeth Beck-Gernsheim, Individualization: institutionalized individualism and its social and political consequences (London: Sage Publications, 2002), 203-04, the authors termed "zombie categories" to social categories such as gender, class, family, level of education, etc., and they assert that these categories no longer have the empirical validity that sociology generally ascribed to them.

${ }^{6}$ In David Harvey, The Condition of Postmodernity: An Enquiry into the Origins of Cultural Change, (Massachusetts: Blackwell Publishers, 1990), 106, the author states that "the result is to exacerbate insecurity and instability, as masses of capital and workers shift from one line of production to another, leaving whole sectors devastated, while the perpetual flux in consumer wants, tastes, and needs becomes a permanent locus of uncertainty and struggle." 
boundaries - and, consequently, individuals are, themselves, the last boundary of social, political, and economic action.

From the 1960s, in opposition to the modernist imaginary, urban life developed the production of images and signs before the old notion of objects and commodities. Further evidence for this is the artistic and architectural movements of the 1960s and 1970s that rejected the aesthetic monotony of modern art with its will to state absolute truths and metanarratives. These changes in production during the Keynesian-Fordist period imply a flexible accumulation of capital. The flexible production develops a system to solve problems effectively. Speed and specialization are two words that accurately describe this intent to satisfy the individual demand. Consequently, societies experienced a change from collective norms and values to a competitive individualism, which turns out to be the central value and necessary condition for this transition. The rise of individualism, as a reflection of the fragmentation of the old cultural order, reshaped Western societies.

\subsection{Ulrich Beck: Second Modernity and the World Risk Society}

In the introductory chapter of The Risk Society, Ulrich Beck argues that the nuclear accident that occurred in Chernobyl, Ukraine means a setback for the progress of Modernity. After this tragedy, global risks are perceived as collective and beyond the possibilities of individual action. The ultimate cause of these threats is capitalism since

risk is derived as a product of economic development. The modern connection between economic and social development that resulted in the social division of classes is challenged. The extent of the dangers exceeds the individuals' possibilities to respond; 
they are external to the jurisdiction of individuals; therefore, they imply the whole society and, eventually, will result in the collapse of the whole system. Within such a process, the idea of class division based on work changes into a more complete symbolic construction in which nobody is safe.

This transformation has given birth to the society of risk. In Beck's words, "risk may be defined as a systematic way of dealing with hazards and insecurities induced and introduced by modernization itself" ${ }^{p}$ and "in contrast to all earlier epochs (including industrial society), the risk society is characterized essentially by a lack: the impossibility of an external attribution of hazards. In other words, risks depend on decisions; they are industrially produced and in this sense politically reflexive." ${ }^{8}$

Becks' main thesis reads

Modern society's belief in linear modernization contradicts the self-disenchantment of Modernity, its ability to epochal change, to self-transformation.... I maintain that the apparently independent and autonomous system of industrialism has transgressed its logic and boundaries and has thereby begun a process of self-dissolution. We are witnessing a dialectics of Modernity: continuity of the principles and discontinuity of basic institutions of nation-state Modernity. This radical turn marks the current phase in which modernization is becoming reflexive.... Because modernization is now impinging upon the very social, political and cultural basic institutions of industrial society of nation-state, is breaking them down and is giving rise to new potentials in opposition to industrial Modernity; that is, for environmental sub- and (authoritarian) statepolitics; emerging cultures and movements of participation; a profound critique not only of neoliberal capitalism, but also of the hierarchically organizing practices of the traditional left; and-last but not least - a New Critical Theory. In this way, the process of

\footnotetext{
${ }^{7}$ Beck, Risk Society, 21.

${ }^{8}$ Ibid., 183.
} 
reflexive modernization is leading from the national industrial society to the (still indeterminate ambiguity of) world risk society. ${ }^{9}$

His theory of second Modernity, as the German author analyzed in the light of the events of 11 September 2001, can be divided in three theorems, namely: individualization, multi-dimensional globalization or cosmopolitanization, and risk society. All three theorems change the logic of unequivocalness - the linear conception of history, society, and politics of the first Modernity — for a logic of ambiguity — the principle of indeterminacy of history, society and politics of second Modernity. Individualization, far from being a moral category similar to selfishness or egocentrism, is the result of a long history of modern contexts, particularly "Christian individualization through confession and the institutionalized individualization of civil, political, and social rights" 10 enshrined by the welfare state. For the addressee of these fundamental rights is the individual itself, and not the collective. Both forms of "interiorized institutional individualization" compel individuals to reflect on themselves and to assume responsibilities for the social consequences of individual acts. According to Beck, on the one hand, this shows the power of religion to shape individuals' mentalities and institutions without this power being reflected; on the other hand, Christianity evaporated into the acquired social rights of the welfare state. He continues his analysis to show how individualization is made permanent in both the welfare stateindividual rights — and Christian churches — individual faith — with the paradoxical

\footnotetext{
${ }^{9}$ Ulrich Beck, "World at Risk: The New Task of Critical Theory," Development and Society 37, no. 1 (2008): 2; http://www.jstor.org.ezproxy.fiu.edu/stable/deveandsoci.37.1.1.

${ }^{10}$ Ulrich Beck, "Individualism," in The Wiley-Blackwell Encyclopedia of Globalization, edited by George Ritzer, Blackwell Publishing Ltd, 2012, DOI:10.1002/9780470670590.wbeog292
} 
consequence that the monopoly of faith and truth is eroded and the boundaries between religiosity and irreligiosity are blurred. ${ }^{11}$

Cosmopolitanization refers to the situation in which "the nation-state is increasingly besieged and permeated by a planetary network of interdependency, by ecological, economic, and terrorist risks, which connect the separate worlds of developed and underdeveloped countries." 12 Therefore, individuals view themselves at the same time as part of a risky globalized world and as part of their local situations and individual histories. Religion plays a role in such a scenario. World religions overcome social hierarchies and frontiers between nations and ethnicities. They are able to do so since they extend a religious universalism which extends the ambivalence of tolerance and violence that marks the history of world religions. He quotes, thus, Peggy Levitt's famous passage: "Religion is the ultimate boundary crosser. God needs no passport because faith traditions give their followers symbols, rituals, and stories they use to create alternative sacred landscapes, marked by holy sites, shrines, and places of worship."13

Risk means potential danger, anticipated catastrophe. "The risk society are manufactured uncertainties, that is a range of new risks - for example, environmental problems — which are unintended side effects of technological and economic development. These manufactured uncertainties result from scientific and technological

\footnotetext{
11 Ibid.

12 Beck, "World at Risk": 4.

${ }^{13}$ Peggy Levitt, God Needs No Passport: Immigrants and the Changing American Religious Landscape (New York: The New Press, 2007), 12, quoted in Ulrich Beck, "Religion, world," in The Wiley-Blackwell Encyclopedia of Globalization, edited by George Ritzer, Blackwell Publishing Ltd, 2012. DOI:10.1002/9780470670590.wbeog492
} 
progress, which supposedly should solve, not create problems." ${ }^{14}$ Consequently, the global anticipation of risks puts into perspective the foundation and certainties of modern societies since global risks are delocalized - their causes and consequences are not geographically limited. Moreover, the consequences of the risks are incalculable and impossible to know. Thus, they break down the modern logic of compensation because if climate change is irrevocable, intervention in human biology by genetics is irreversible, and terrorist groups possess weapons of mass destruction, then "it's too late."15

Therefore, Beck's Critical Theory of World Risk Society discloses a global world full of uncertainties, doubts, and risks, a product of the last phase of capitalism that the people have to face by their own since individualism reigns as a historical result.

\subsection{Zygmunt Bauman: Liquid Modernity and Consumer Society}

In the last decades of the twentieth century, the Polish intellectual Zygmunt Bauman acquired a reputation as a leading theorist of Postmodernity. However, in contrast to the widespread view of many scholars who argued that the postmodern condition signified a radical break with the project of Modernity, Bauman contended that this last phase of Modernity is a consequence, a result of the modern ideals. For this reason, and feeling that the term "postmodern" was fuzzy, he forged the concept of "Liquid Modernity."

\footnotetext{
${ }^{14}$ Beck, "World at Risk": 5.

${ }^{15}$ Ibid., 6. In Ulrich Beck, "Global Risk Society," in The Wiley-Blackwell Encyclopedia of Globalization, edited by George Ritzer, Blackwell Publishing Ltd, 2012, DOI:10.1002/9780470670590.wbeog242, the author offers a remarkable synthesis of the three characteristics of risks and uncertainties, namely delocalization, incalculableness, and non-compensability.
} 
Bauman asserts that dual and ambivalent nature is at the base of Modernity. On the one hand, Modernity has always pursued a rational order through organizational forms, particularly bureaucracy. Human beings would control, predict, and understand the world as far as they were able to domesticate, categorize, and rationalize it. Agreeing with Max Weber, he holds that ordering, as a modern rationalizing tendency, distinguishes Modernity. On the other hand, modern society experiences vertiginous changes at an increasing speed. The modern centuries have witnessed the overthrowing of traditional forms of economy, culture, national projects, and governments. Bauman, thus, applies the words of Engels and Marx's Communist Manifesto-_"all that is solid melts into air"16 — to Modernity. ${ }^{17}$ Therefore, Bauman coined the term Liquid Modernity, on the one hand, to express the new condition resulting from the failure to rationalize the world and the consequent magnification and acceleration of constant change and, and on the other hand, to show a line of continuity within Modernity. We are in the path from a solid Modernity to a liquid Modernity, in which motion and change are ubiquitous.

For Bauman, the adaptations of capital ground this path. In fact, he describes how in solid Modernity, which was ruled by production, "the task confronting free individuals was to use their freedom to find the appropriate niche and to settle there through conformity." "18 In Liquid Modernity, governed by consumption, such patterns, codes, and rules are in increasingly short supply. For Bauman, consumption is an ecosystem, a

\footnotetext{
${ }^{16}$ Friedrich Engels and Karl Marx, The Communist Manifesto (The Project Gutenberg, 2005), loc. 59 of 630, Kindle.

${ }^{17}$ Bauman, Liquid Modernity, 3.

${ }^{18}$ Ibid., 7.
} 
culture, and a total social fact that defines the ontological condition of individuals. The Polish philosopher describes consumption as being in movement. Solid Modernity is the world of Henry Ford's factories and automotive unions. In such a world, capital demonstrated its power over labor by the ability to control and order. In the solid Fordist factories, capital wielded power by attaching human labor to machines as a symbol of production.

In Liquid Modernity, capital no longer ties down labor since capital itself is now free, untied from space, and light. The power of capital is to escape, to flow, to avoid, to elude, and to be flexible. "Flexibility' is the slogan of the day, and when applied to the labor market it augurs an end to the 'job as we know it,' announcing instead the advent of work on short-term contracts, rolling contracts, or no contracts, positions with no in-built security but with the 'until further notice' clause. Working life is saturated with uncertainty." 19 In Liquid Modernity, capital itself is liquid. Whereas the employee at the Ford factory would spend his whole life working under that structure, the freelancer and the software engineer will have to move constantly within the market. In the time of software, "capital travels hopefully. Capital can travel fast and travel light, and its lightness and its mobility have turned into the paramount source of uncertainty for all the rest." ${ }^{20}$ It leads individuals to continuously search for some futile certainties not in the production since capital tries to avoid the responsibility of maintaining a labor force, but in consumption.

\footnotetext{
${ }^{19}$ Bauman, Liquid Modernity, 147.

${ }^{20}$ Ibid., 121.
} 
In the first chapter of Consuming Life, ${ }^{21}$ Bauman expresses that consumption is a permanent condition for survival, and therefore, an "occupation of individual human beings." ${ }^{22}$ However, he differentiates between consumption and consumerism. The latter turns consumption into the goal of human life and, therefore, "is an attribute of society" that results from the "recycling [of] human wants, desires, and longings into [the] principal propelling and operating force of society." 23 The alienated desires of the individuals of consuming societies lead them to the appropriation of goods that provide self-esteem and security. The presence and validity of religion itself may be sociologically understood as one of these goods that believers consume, which is moved by the search for certainty and security. ${ }^{24}$ However, the constant increase of the intensity of desires leads individuals to the permanent replacement of the desired goods since the promised satisfaction is never achieved.

${ }^{21}$ In Ernesto Fiocchetto, "Forty-Five Minutes of Intense Connectivity," I evolve in the relationship between consumption, religion and performed identities in digital societies. This paragraph is partially taken from this work.

${ }^{22}$ Zygmunt Bauman, Consuming Life (Massachusetts: Polity Press), 2007, 25. He develops the concept by saying: "Indeed, if reduced to its archetypical form of the metabolic cycle..., consumption is a permanent and irremovable condition and aspect of life, bound by neither time nor history; one of the inseparable elements of biological survival which we, humans, share with all other living organisms. Seen in that way, the phenomenon of consumption has roots as ancient as living organism-and most certainly it is a permanent, integral part of every form of life known from historical narratives and ethnographic reports."

${ }^{23}$ Bauman, Consuming Life, 28.The cite reads: "We may say that 'consumerism' is a type of social arrangement that results from recycling mundane, permanent and so to speak 'regime-neutral' human wants, desires and longings into the principal propelling and operating force of society, a force that coordinates systemic reproduction, social integration, social stratification and the formation of human individuals, as well as playing a major role in the processes of individual and group self-identification and in the selection and pursuit of individual life policies."

${ }^{24}$ See Danièle Herview-Léger, "In Search of Certainties: The Paradoxes of Religiosity in Societies of High Modernity," The Hedgehog Review 8, no. 1-2 (Spring-Summer 2006): 59-68. Academic OneFile. 
"Thus, consumption is nothing but being in constant motion." 25 In Liquid Modernity, patterns to which we could conform are no longer given or self-evident; the number of them increases ubiquitously; they clash and contradict one another; they flow. Consumerism, hence, describes that society in which the principal operation force that coordinates social integration and the formation of identities are desires that, by definition, are never to be satisfied. This dissatisfaction, which is both a venue for modern religion and the possibility for the constant readaptations of capital, is the motor of consumption as motion.

\subsection{Anthony Giddens: Late Modernity and Post-Traditional Society}

Anthony Giddens also agrees that "we have not moved beyond Modernity but are living precisely through a phase of its radicalisation" 26 and, accordingly, he speaks about Late Modernity to emphasize continuity and change, rather than break or disjuncture. He characterizes Late Modernity as dynamic and distinguishes three dominant sources of its dynamism, each connected with the other. ${ }^{27}$

The separation of time and space. In pre-modern societies, “"when’ was almost universally either connected with 'where.'... The invention of the clock... expressed a uniform dimension of 'empty' time, quantified in such a way as to permit the precise

\footnotetext{
${ }^{25}$ Ernesto Fiocchetto, "Forty-Five Minutes of Intense Connectivity."

${ }^{26}$ Anthony Giddens, The Consequences of Modernity (California: Stanford University Press, 1990), 51.

${ }^{27}$ Ibid., $17-54$.
} 
designation of 'zones' of the day." 28 As a result, there has been standardization and globalization of time, and everyone now follows the same time and date systems which turned out to be autonomous of real spaces. "The 'emptying of time' is in large part the precondition for the "emptying of space." ${ }^{29}$ In pre-modern societies, space and place coincide, since the others' presence dominated the spatial dimension of social life. Modernity increasingly separates place from space by articulating relations between absent others. All in all, "time and space are recombined to form a genuinely worldhistorical framework of action and experience." 30

The development of disembedding mechanisms. Traditional institutions such as family, education, religion, and politics were integral parts of the local societies and allowed the structuration and reproduction of such societies. With the coming of modernization, those institutions became disembedded from local communities. By disembedding Giddens, thus, means "the 'lifting out' of social relations from local contexts of interaction and their restructuring across indefinite spans of time-space."31

Such a process takes place through two types of disembedded mechanisms: symbolic tokens and expert systems. Symbolic tokens are media of interchange that can be "passed around" without regard to individual or group characteristics. ${ }^{32}$ The best example of a symbolic token is the money whose exchange disturbs the perception of

\footnotetext{
${ }^{28}$ Ibid., 17.

${ }^{29}$ Ibid., 18.

${ }^{30}$ Ibid., 21.

31 Ibid.

32 Ibid., 22-27.
} 
space and time because, in Late Modernity, money provides for the inmediate enactment of transactions between agents widely separated in time and space. Expert systems are systems of technical accomplishment or professional expertise consisting of engineers, doctors, architects, lawyers, and so forth who run the community by organizing large areas of the material and social environments in which we live today. ${ }^{33}$ Thus, the manner that individuals relate to housing, health, or personal problems is not direct but mediatized by those experts. This mediation puts into perspective the notion of timespace based on a weak inductive knowledge. Therefore, "all disembedding mechanisms, both symbolic tokens and expert systems depend upon trust. Trust is therefore involved fundamentally with the institutions of Modernity. Trust here is vested, not in individuals, but in abstract capacities." ${ }^{\prime 34}$ Individuals need to trust because they live in "environments of risk" that collectively affect large masses of individuals. ${ }^{35}$

The reflexive appropriation of knowledge. Two notions are fundamental to properly understand this source of modern dynamism. First, Giddens asserts that "inherent in the idea of Modernity is a contrast with tradition." ${ }^{36}$ Second, he states that "all human beings routinely 'keep in touch' with the grounds of what they do as an integral element of doing it," ${ }^{37}$ what he calls "reflexive monitoring of action." In traditional cultures, there is a mode of integrating the reflexive monitoring of action with

\footnotetext{
${ }^{33}$ Ibid., 27-29.

${ }^{34}$ Ibid., 26.

${ }^{35}$ Ibid., 33-36

${ }^{36}$ Ibid., 36.

${ }^{37}$ Ibid.
} 
the time-space organization of the community, and thus, reflexivity is limited to the reinterpretation of tradition. This limit of reflexivity is challenged in modern societies, in which reflexivity "is introduced into the very basis of system reproduction, such that thought and action are constantly refracted back upon one another." ${ }^{38}$ In other words, reflexivity is the regular use of knowledge by institutions and individuals who continuously explain their actions through this knowledge and create or change modern systems and forms of social organization. Social practices are regularly examined and reformed in the light of incoming information about those very practices. The production of systematic knowledge about social life becomes integral to system reproduction, rolling social life away from the fixities of tradition. Moreover, this does not mean that tradition disappears; rather, actions guided by tradition in Modernity are reflexively justified.

In sum, Late Modernity is post-traditional. The lack of analysis of individual actions that was possible within societies in which tradition dominated, increasingly turned into a much more reflexive attitude towards social life and all its dimensions, including religion and the configuration of identities. Consequently, while earlier societies with a social order based firmly in tradition would provide individuals with clearly defined roles and identities, in post-traditional societies, we have to work out our roles for ourselves. In Giddens' words, "What to do? How to act? Who to be? These are focal questions for everyone living in circumstances of Late Modernity — and ones which, on some level or another, all of us answer, either discursively or through day-to-day

\footnotetext{
${ }^{38}$ Ibid., 38.
} 
social behavior" ${ }^{39}$ Consequently, in Late Modernity, self-identity is a reflexive project of the self.

\section{Toward the Comprehension of Religion in High Modernity: The Contribution of Danièle Hervieu-Léger}

Danièle Hervieu-Léger, a leading scholar in the sociology of religion in the Frenchspeaking world, has also made an original and influential contribution to the debate about religion in the context of Late Modernity. Influenced by the French style of sociology, she draws extensively from theoretical and empirical texts and provides insightful perspectives into the major discussions of the sociology of religion, including secularization, individuation, identities, and new religious expressions. Her work is principally focused on France and, by extension, on Europe. However, her work has been very influential in Latin America. Many scholars have repeated and adapted her concepts to understand religion in the subcontinent. In contrast, her influence in North America has been minor. Indeed, though most of her work is translated into Spanish, it remains untranslated into English, which has been a challenge in this thesis.

This section aims to tackle some aspects of the definition of religion that the French sociologist has developed. Nevertheless, we can properly understand her concepts in the context of her approach to secularization, which I will address firstly. Secondly, I will develop her concept of religion as a chain of memory, which is the heart of her sociological theory. Lastly, the paradoxical nature of religion will be tackled in order to

\footnotetext{
${ }^{39}$ Giddens. Modernity and Self-Identity, 70.
} 
complete an approach to Hervieu-Léger's thought. Throughout this section, I will broach other scholars that might help synthesize her thought or add new perspectives for a better understanding of the research problem at hand.

\subsection{Secularization}

Hervieu-Léger challenges the modern thesis of secularization. She states that sociologists have focused on the reasons why religion is in decline and they have argued that such a decline had come about as a result of the impact of modernization and the ensuing secularization that seemed to have disintegrated religion. These perspectives are based on the modern idea that prognosticated the withdrawal of the religious experience to the private sphere. According to this perspective, modern societies would resettle religion in social life by depriving it of its active role since "Modernity and religion are mutually exclusive. ${ }^{" 40}$ Further evidence for this can be found in Émile Durkheim's doctoral thesis when he asserts that

there is one truth that history teaches us beyond doubt, it is that religion tends to embrace a smaller and smaller portion of social life. Originally, it pervades everything; everything social is religious; the two words are synonymous. Then, little by little, political, economic, scientific functions free themselves from the religious function, constitute themselves apart and take on a more and more acknowledged temporal character. God, who was at first present in all human relations, progressively withdraws from them; he abandons the world to men and their disputes. At least, if he continues to dominate it, it is from on high and at a distance, and the force which he exercises, becoming more general and more

\footnotetext{
${ }^{40}$ Danièle Hervieu-Léger, "Religion and Modernity in the French Context: For a New Approach to Secularization,” Sociological Analysis 51 (1990): 15.
} 
indeterminate, leaves more place to the free play of human forces. $^{41}$

Contrastingly, Hervieu-Léger argues that the rational disenchantment characteristic of modern societies does not mark the end of religion. It has not caused the disappearance of the need to believe. On the contrary, as the authors in the previous section disclosed, the advances of rationality together with capitalism resulted in a global world full of risks and uncertainties that are fertile ground for religion. In her perspective, this assertion formed the starting point, in the 1970s, of a theoretical revival in the sociology of religion. It paved the way for a significant re-evaluation of the secularization process, a task still far from complete. It has become clear that belief proliferates in proportion to the uncertainty caused by the mobility of Liquid Modernity perceptible in all areas of social life. At root, "secularization is not, primarily, the loss of religion in the modern world. It is the set of processes of readjustment of the beliefs that is produced in a society whose engine is the insatiability of the expectations that the society itself raises, and whose daily condition is the uncertainty linked to the never-ending search of the means to satisfy these expectations." 42

In line with Bauman's thesis of the dual and ambivalent nature of Modernity, before the search of rational order, Hervieu-Léger observes an increasing loss of control of the established religious institutions over the belief systems and religious practices of individuals; hence, a gap between the official forms of religion and individually accepted

\footnotetext{
${ }^{41}$ Émile Drukheim, Division of Labor in Society (Illinois: The Free Press of Glencoe, 1960), 188.

${ }^{42}$ Danièle Hervieu-Léger, El Peregrino y el Convertido: La religión en movimiento (Mexico D.F.: Ediciones del Helénico, 2004), 43. (My translation)
} 
religious perceptions and behaviors emerges. Individuals are more and more freed from established religious authorities and thus enabled to determine their belief systems autonomously, often synthesizing various religious traditions. This process of religious individuation does not mean that individual religiosity is weakened. Instead, it becomes multifaceted, syncretistic, hybrid, and alienated from institutions.

Consequently, for Hervieu-Léger, it has become clear that belief proliferates in proportion to the uncertainty caused by Modernity. However, it is also clear that in societies that have adopted the autonomy of individuals as a principle, belief less and less sits on institutional dogmatic frameworks. On the contrary, individuals create their own small systems of belief that fit their own aspirations and expectations. Given this, Hervieu-Léger elaborates on two core concepts that depict this process. ${ }^{43}$ The notions that Beck, Bauman, and Giddens offer about Late Modernity, especially those of individualization and disembedding mechanisms, are the context in which we can situate the contributions of the French sociologist.

Firstly, she asserts that modern societies go through a process of individuation of beliefs. Individuals write their own little religious narratives using words and symbols that escape the constellations of meanings in which a given tradition has set them over the centuries; hence, the unpredictable diversity of these individual compositions of beliefs, which may include elements borrowed from a wide variety of symbolic resources. This exaltation of individuality is part of a deeper movement in which the governing systems of truth are being displaced, as the first section of this chapter evinces.

${ }^{43}$ Hervieu-Léger, "In Search of Certainties": 59-60. 
Legitimation of beliefs is moving from religious authorities to individuals themselves, who are responsible for the authenticity of their own spiritual approach, "since all preexisting 'foundations' of epistemology have been shown to be unreliable." 44

Secondly, the other concept that Hervieu-Léger offers consists of one that she names the process of religious deinstitutionalization. The organized structure of belief systems authenticated by religious institutions is weakening. Putting into perspective the orthodoxies that institutions uphold shows the novelty of the rejection in strictly spiritual terms of an institutional means of authenticating religious truth. Such an institutional authentication had represented for centuries both the base for the unquestioned universal validity of the major religions and the ground for the denominational definitions that identify different churches. ${ }^{45}$

At this point, it is clear that in this work secularization does not mean the loss of religion, but rather readjustment of beliefs in a fluid and flexible context for individuals and institutions. This changing reality led Hervieu-Léger to address what she believes is the central question that confronts scholars who are trying to provide sociological insight concerning contemporary religion. That question involves coming to understand "the intellectual approach required to grasp both the dimension by which Modernity continually undermines the plausibility structures of all religious systems and that by which it gives rise to new forms of religious belief." 46 One of her most important works,

\footnotetext{
${ }^{44}$ Giddens, The consequences of Modernity, 46.

${ }^{45}$ Hervieu-Léger, "In Search of Certainties": 60.

${ }^{46}$ Danièle Hervieu-Léger, Religion as a Chain of Memory (New Brunswick, N.J.: Rurgers University Press, 2000), 2.
} 
Religion as a Chain of Memory, tackles these aspects through the category of memory, especially when defining the concept of religion.

\subsection{Religion as a Chain of Memory}

Hervieu-Léger's Religion as a Chain of Memory has its roots in the Durkheimian approach to religion, as modified by Maurice Halbwachs. Borrowing heavily from the concept of collective consciousness in which Durkheim asserts that people in a community share common beliefs and sentiments, Hervieu-Léger introduces her concept of memory, which, like Durkheim's collective consciousness, points to the importance of a shared tradition, a kind of lineage, thread, or chain that shapes individuals and communities. The main thesis that runs through Religion as a Chain of Memory is that no society, even if it is shaped by the most advanced Modernity, can renounce entirely at least a minimum thread of continuity inscribed in reference to the authorized memory that is a tradition. ${ }^{47}$ This thesis makes it possible to go beyond the traditional opposition between traditional societies where "religion is everywhere" and modern societies where religion is concentrated in a specialized sphere.

Defining religion has long posed a serious problem for sociologists. HervieuLéger expends considerable space in the early chapters of her work exploring this problem in an effort to come to terms with it. ${ }^{48}$ Nevertheless, developing a definition is

\footnotetext{
${ }^{47}$ Hervieu-Léger, El peregrino y el convertido, 23.

${ }^{48}$ Further evidence for the challenging task of defining religion for specialized scholars is the extensive approach that Thomas Tweed also does in the first part of his Crossing and Dwelling to tackle the problem of definition. See Thomas Tweed, Crossing and Dwelling: A Theory of Religion (Cambridge, Massachusetts, and London: Harvard University Press, 2008), chapters 1 to 3.
} 
critical to Hervieu-Léger's attempt to explain the role of religion in the modern world. She dismisses commonly used sociological definitions of religion, both substantive ones that focus on the contents and meaning of belief and functional ones that describe the operations and purposes of religion. ${ }^{49}$ Hervieu-Léger concludes that the development of a definitive definition of religion may not be possible; therefore, she creates a working definition — a framework for thinking religion — that does not essentially describe the object of religion, but identifies the broader aspects of religion that are always moving, recomposing, and restructuring.

She argues that religion might be defined as "an ideological, practical and symbolic system through which consciousness, both individual and collective, of belonging to a particular chain of belief is constituted, maintained, developed and controlled." 50 What Hervieu-Léger suggests in her definition is that religion in the modern world can only be comprehended if it is understood as a way of believing that is rooted in an authoritative tradition, that is, a chain of belief that is all-absorbing for the believer. Hervieu-Léger notes that religion is not open to modern rational scrutiny; rather, it is the act of believing within a religious tradition that legitimates it. Consequently, there are three main axes in her approach to religion, namely memory, belief, and chain.

Memory. Change has been one of the most defining characteristics of modernization, as Bauman states. Such change has been highly corrosive of memory,

\footnotetext{
${ }^{49}$ Hervieu-Léger, Religion as a Chain of Memory, 23-41.

${ }^{50}$ Ibid., 82.
} 
tradition, and religion. ${ }^{51}$ Theories of secularization that attempt to explain the supposed increasing loss of religion have for the most part not considered the loss of memory. Hervieu-Léger asserts that the transmutation of memory has a massive impact on the manner in which Modernity shapes religion. She points out that in past tradition-based societies, where distinctive communities of faith emerged and where established religions prevailed, religious memory was produced through constantly recurring construction. Those who lived in such societies reinforced religious memory through defining their identity as a living lineage of belief and through acting out their belief in rituals. According to Hervieu-Léger, fluidity and change in the modern world fragmented or obliterated the memory of the past and tradition, both of which were so central to making religion meaningful for their believers. She observes that the changes of "industrialization, urbanization, the spread of trade and interchange mark the waning of the social influence of religion and the piecemeal destruction of communities, societies and even ideologies based on memory." 52 Religion, accordingly, lost power as a collective social memory, and a plurality of specialized, fragmented memories — such as family memory, national memory, class memory, and even religious memory — appeared.

In traditional societies, collective memory was totally contained within the structures of society; there was no need to emphasize this link with past memories, as there was no threat to the chain of memory. Contrastingly, in modern differentiated society, collective memory is subject to constant reconstruction. The limitless

\footnotetext{
${ }^{51}$ Tuula Sakaranaho, "Religion and the Study of Social Memory," Temenos: Nordic Journal of Comparative Religion 47, no. 2 (2011): 138-40.

${ }^{52}$ Hervieu-Léger, Religion as a Chain of Memory, 127.
} 
fragmentation of individual and group memory is gradually desintegrating collective memory. ${ }^{53}$ Society is characterized by high mobility, remoteness of social relations, and uncertainty; it is a society in which everything fragments: "Humans are actors without a system, enclosed in their imagination and memory, adrift in a universe without fixed bearings. ${ }^{54}$

Alongside this fragmentation of memory, post-modern society is amnesiac, less and less able to remember, and thus to maintain the chain of memory that binds it to the past. However, paradoxically, this has not removed the need of the individual or the society to belong; indeed the uncertainty has made the need stronger. ${ }^{55}$ In a society that is not producing societies of memory, but is characterized rather by discontinuity, the individual seeks out voluntary communities, to gain a sense of belonging. ${ }^{56}$

Belief. Hervieu-Léger argues that belief is still a central dimension of Modernity, it has just shifted its function and location. In her perspective, that mostly coincides with Beck's, Bauman's, and Giddens', scientific and technical rationality displaces the primordial question of why to the pragmatic question of how. ${ }^{57}$ Therefore, the advances of science and technique would reduce the space for believing in modern society. In any case, those undeniable signs of progress did not disappear the human necessity for meanings. The more societies can manipulate their own worlds, the more uncertainty and

\footnotetext{
${ }^{53}$ Ibid., 129.

${ }^{54}$ Ibid., 165.

${ }^{55}$ Ibid., 141.

${ }^{56}$ Ibid., 123.

${ }^{57}$ Ibid., 73.
} 
risk appear. Consequently, the question of why rises once more in very different ways;

hence, the venue for believing in Modernity. ${ }^{58}$ Given this, she understands belief as

The body of convictions - both individual and collective - which are not susceptible to verification, to experimentation and, more broadly, to the modes of recognition and control that characterize knowledge, but owe their validity to the meaning and coherence they give to the subjective experience of those who hold them. If one here talks about believing rather than belief, it is in order to include not merely beliefs in the accepted sense, but all the resources of observance and language and the involuntary action which such belief in its multiple forms displays: believing is belief in action, as it is experienced. ${ }^{59}$

Therefore, there is no human action that does not generate belief. Each human activity produces a different kind of belief or system of belief according to its characteristics. Hence, we find ourselves before the possibility of a development of beliefs in different spheres of social life since beliefs exceed the realm of religion. ${ }^{60}$ Being that belief is present in all human actions, it is necessary to define the specificity of the religious belief.

Chain. For Hervieu-Léger, "what matters here is not the actual substance of belief but the ingenuity, the imaginative perception of the link which across time establishes the religious adhesion of members to the group they form and the convictions that bind them. Seen thus, one would describe any form of believing as religious which sees its

\footnotetext{
${ }^{58}$ The connections with Giddens' notion of "trust" are clear, especially when he asserts: "trust is therefore involved fundamentally with the institutions of Modernity." (Giddens, The Consequences of Modernity, 26.)

${ }^{59}$ Hervieu-Léger, Religion as a Chain of Memory, 72.

${ }^{60}$ In her book, Hervie-Léger analysis rock concerts, politics, and sport in France as systems of beliefs.
} 
commitment to a chain of belief it adopts as all-absorbing." 61 Thus, she elaborates on a structural connection between religion and memory. "Religion implies a specific mobilization of the collective memory," $" 62$ and thus religion is defined by a specific mode of believing rather than by the content of the belief. This perspective needs further consideration.

Firstly, such a specific mode of believing consists of the practice of anamnesisthe recalling to the memory of the past—which is usually performed as a rite. According to Grace Davie, who closely follows Hervieu-Leger's theoretical framework, the French author goes further: "she argues that modern societies are not less religious because they are increasingly rational but because they are less and less capable of maintaining the memory which lies at the heart of their religious existence. They are, to use her own term, amnesic societies."

Secondly, this anamnesis introduces the individual within a believing lineage. Religion establishes a particular thread of continuity among believers from generation to generation. There is an authoritative tradition - a collective memory - that legitimates the belief. She depicts this chain with a suggestive phrase: "as our fathers believed, and because they believed, we too believe." ${ }^{\prime 4}$ The belief is considered religious from the

\footnotetext{
${ }^{61}$ Hervieu-Léger, Religion as a Chain of Memory, 81. (The author's emphasis.)

${ }^{62}$ Hervieu-Léger, El peregrino y el convertido, 9.

${ }^{63}$ Grace Davie, Religion in Modern Europe: A Memory Mutates (Oxford and New York: Oxford University Press, 2000), loc. 469-470 of 3508, Kindle.

${ }^{64}$ Hervieu-Léger, Religion as a Chain of Memory, 81.
} 
moment that the believer puts forward a logic of causation that leads him/her to believe what he/she believes. ${ }^{65}$

Thirdly, since the emphasis is placed in the chain of memory that is legitimated by a believing lineage, Hervieu-Léger rejects the sacred as an essential part of religion. On the one hand, sacredness can be also found in those other modes of belief outside religion, like in rock concerts, sports, or politics. Accordingly, the worshipping of a rock hero turns to be a religious phenomenon. On the other hand, the overarching arching sacred canopy no longer makes sense in the modern world as an essential part of religion. Confronting Peter Berger, she states that Modernity breaks with the sacred in that it invests humanity with the task of rationalizing and ordering the world. "But the fundamental need to dispel the essential uncertainty of the human condition is not diminished simply because the 'sacred cosmizations' (Peter Berger) are brought to naught by the process of rationalization." 66

Lastly, the religious group defines itself objectively and subjectively as a "chain of memory" whose continuity transcends history. The continuity is witnessed and manifested in the specifically religious act of anamnesis — making memory —of the lineage that links the individual and the group to a past, gives meaning to the present, and opens up to a future. ${ }^{67}$ There is an authorized memory that gathers the group as a

\footnotetext{
${ }^{65}$ Hervieu-Léger, El preregrino y el convertido, 22-23.

${ }^{66}$ Hervieu-Léger, Religion as a Chain of Memory, 73.

${ }^{67}$ Daniele Hervieu-Léger, "Producciones de la Modernidad Religiosa," in Modernidad, Religión y Memoria, ed. Fortunato Mallimaci (Buenos Aires: Ediciones Colihue, 2008), 38.
} 
religious group. Therefore, the kernel of the religious power will sit on the recognized capacity of establishing the "true memory" of the group.

\subsection{Some Paradoxes of Religious Modernity ${ }^{68}$}

The chain of memory that is a religious tradition is thus challenged both by fragmentation and by collective amnesia. A consequence of this fragmentation is the individuation of beliefs - the individual believer's relationship with tradition becomes voluntary. In Late Modernity, the concept of God becomes increasingly subjective. Individuals simply "pick and mix" from divers options on offer. Religion enters the world of options, lifestyles, and preferences. ${ }^{69}$

In order to describe such a consequence of the individuation of beliefs, HervieuLéger uses the term religious bricolage —making creative and resourceful use of whatever materials are at hand regardless of their original purpose. ${ }^{70}$ It is a "playing of the code." ${ }^{.71}$ The religious traditions are thus symbolic repositories of meaning available for individuals to use and reuse in different ways. ${ }^{72} \mathrm{~A}$ characteristic of modern society is

\footnotetext{
${ }^{68}$ The title of this section is taken from an article of the French author. The English version of this text was titled "In search of Certaintites: The Paradoxes of Religiosity in Societies of High Modernity." However, the English title uses the word "religiosity" which is not in Hervieu-Léger's theoretical universe. I have decided for a more literal translation of the French title "Quelques paradoxes de la modernité religieuse: Crise de l'universel, planétarisation culturelle et renforcements communautaires", first published in January 2001.

${ }^{69}$ Davie, Religion in Modern Europe, loc. 390-93 of 3508, Kindle.

${ }^{70}$ Danièle Hervieu-Léger, "The transmission and formation of socio-religious identities in Modernity: An analytical essay on the trajectories of identification," International Sociology 13, no. 2 (1998): 213-28.

${ }^{71}$ Ibid., 217.

${ }^{72}$ Danièle Hervieu-Léger, "The role of religion in establishing social cohesion," Eurozine, 17 (August 2006).
} 
not only that people practice bricolage, but that they also assert a right to bricolage, producing for themselves their own relationship to the lineage. ${ }^{73}$ Consequently, the symbol market increases and widens. ${ }^{74}$ In this game of individualized belief composition, believers display varied do-it-yourself skills, corresponding to differentiated social aptitudes.

Hervieu-Léger argues that the other side of the coin is the deinstitutionalization process. Legitimation of beliefs does not lay any more on religious authorities and institutions. The British sociologist of religion Grace Davie reaches similar conclusions, especially in her books Religion in Britain since 1945: Believing without Belonging and Religion in Modern Europe: A Memory Mutates. Her studies consider the changing nature of religion in Northern Europe and, in continuous feedback with Hervieu-Léger's works, she analyzes the complex relationship between religious belief and religious belonging. ${ }^{75}$ She considers that the connection between belief and religious practice is central to this discussion. Almost all empirical investigations of religion in Northern Europe support the contrasting ideas of a manifest reduction in the hard indicators of religious life, such as attendance to the cult, on the one hand, and a persisting belief in God, on the other. "It is precisely this state of affairs, moreover, which is captured by the phrase 'believing without belonging,' the popularity of which in both pastoral as well as sociological accounts of religious life in modern Europe indicates, in itself, its perceived

\footnotetext{
${ }^{73}$ Hervieu-Léger, "The transmission and formation of socio-religious": 217.

${ }^{74}$ Hervieu-Léger, "In Search of Certainties": 61-62.

75 Grace Davie, "From Obligation to Consumption: A Framework for Reflection in Northern Europe," Political Theology 6, no.3 (2005): 281. DOI: 10.1558/poth.6.3.281.66128
} 
accuracy. ${ }^{, 76}$ However, she argues that the separating out of belief from belonging does not mean the annihilation of religious institutions. Utilizing, amongst other tools of analysis, the concept of vicarious memory, ${ }^{77}$ she means the notion of religion performed by an active minority - the churchgoers - but on behalf of a much larger number, who understand and approve of what the minority is doing. ${ }^{78}$

In the same vein, the Argentine sociologist Fortunato Mallimaci elucidates both processes - individuation of beliefs and deinstitutionalization — in his own country and in South America, as was developed in the first chapter.

Getting back to Hervieu-Léger's perspective, it is impossible to grasp the social logic of do-it-yourself religious composition without taking into account both the individual's social conditions - the availability of symbolic resources is unequal for each individual and each society—and the cultural conditions of the use of these resources. While the relaxation of institutional control over belief mentioned above favors individualistic dispersion of beliefs, this dispersion still falls within a mechanism of social and cultural restrictions. In a few words, the individual is freer to bricolage his/her system of beliefs, but this freedom is restricted by the social availability of symbolic resources and the cultural use in his/her background. However, these restrictive mechanisms are more and more challenged by the possibilities gained in a globalized context. For Hervieu-Léger, there is no doubt that the pool of symbolic resources upon

\footnotetext{
${ }^{76}$ Ibid.: 283.

${ }^{77}$ Davie, Religion in Modern Europe, loc. 229-1224 of 3508, Kindle.

${ }^{78}$ Davie, "From Obligation to Consumption": 285.
} 
which individuals today are liable to draw in order to make their little personal belief system is undergoing considerable expansion in all societies in the milieu of high Modernity. The possibilities of accessing to a wide range of religious products that the Internet gives us nowadays support this perspective.

At this point, Hervieu-Léger discloses the paradoxical nature of religion in Modernity in three steps. In front of this increasingly broad symbol market, she firstly asserts that "the greater the individuation of belief, the greater its degree of homogenization."79 The rejection of institutional approval of belief and the broadening of the stock of references and symbols made available for use and reuse by individuals does not only signify the fragmentation of small systems of belief. At the same time, the liberalization of the symbol market gives room to a paradoxical tendency towards the standardization of these small narratives: a standardization that makes possible, in a context of general cultural globalization, their arrangement into networks on a worldwide scale. This proclivity for standardization is a very precise response to the mechanisms of a symbol economy increasingly in alignment with the general laws of the market. Further evidence for this first step can be found in charismatic Catholic movements and in evangelical Protestant groups, especially Pentecostal ones, which remarkably adhere to a minimum set of beliefs and similar rituals and liturgies. ${ }^{80}$ This is the precise pivotal point of the standardization of spiritual goods as a production process and of the phenomenon of marginal differentiation, which represents its counterpart, as a consumer process.

\footnotetext{
${ }^{79}$ Hervieu-Léger, "In Search of Certainties": 63.

${ }^{80}$ Ibid.: 63-65.
} 
Secondly, she argues that the greater the homogenization of belief, "the greater the migration among believers." ${ }^{81}$ This homogenization of belief clearly encourages the migration of believers, who define and modulate spiritual courses in which denominational and community boundaries are less and less important. They depict a pilgrim-like form of religiosity, one that is willful, individual, and mobile; not, or only slightly, subject to norms; one that is modifiable and external to the routines governing the daily lives of the individuals concerned. Here we should stress the fluidity brought to these spiritual journeys by the standardization of belief, which enables seekers of meaning to find new shared themes directly associated with typically modern individual requirements, especially regarding the right of each individual to satisfy her/his subjectivity. Two other factors encourage wider-ranging movements of believers beyond their community bases, or even away from their native religious soil. The first is the movement of religious innovation stemming from migration itself, which in return reinforces the homogenization effect. Believers move around and borrow from the various banks of resources available, weaving their own tapestry of meanings along the way. The second factor shaping believer migrations is the mass development of communications that enables the global exchanges through which believers obtain confirmation of their own synthesis of belief.

Lastly, Hervieu-Léger states that "the more individual believers migrate, the greater their need for community niches." ${ }^{\prime 2}$ The extreme acceleration of the circulation of

\footnotetext{
${ }^{81}$ Ibid.: 65.

${ }^{82}$ Ibid.: 66.
} 
beliefs, in particular via the media, stretches the connection between belief and belonging. The whole paradox of religious Modernity lies in the fact that the extreme fluidity of beliefs rarely provides the minima of certainty that they need in order to create their personal identities, as believers called upon to assume their autonomy in all areas. These same individuals that have directed their own spiritual journeys have not eradicated the need to dialogue with others and to testify to their experiences. Indeed, they continue to seek a sharing of certainties. However, the search for a community does not contradict the individuation process. Indeed, the need for subjectivization cannot really be met just through personalized consumption of increasingly standardized symbol goods. For it has the more fundamental aim of making meaning of individual experience. It requires the construction of a narrative, which implies the ability to speak. This ability is inherent to any subject. Moreover, this ability implies the confrontation with an otherness, outside of which no language and recognition is possible. Consequently, it is the action of recognition that, through interaction and dialogue, makes possible the grounding of meanings individually produced and their introduction into social life. In other words, there is no possible religious experience unless the individual, at some point, meets other individuals who are able to confirm the experience for him: "What has meaning for you also has meaning for me." ${ }^{\prime 33}$

If this narration is performed according to a religious mode, that is to say by invoking the continuity of a lineage received from the past and qualified to set a course for the future, then, the narration will constitute the structural axis of any religious

${ }^{83}$ Ibid.: 67. 
identity. Thus, individuation, which dissolves inherited cultural identities and deinstitutionalizes religions, then leads to the constitution, activation, and even invention of small community identities — sometimes inside a bigger community — which are compact, substantial, and compensatory.

\section{Toward the Comprehension of Identities: The Contributions of Francoise Dubet and Claude Dubar}

The last section of this chapter aims to address some theoretical developments that give account of the process of configuration of identities in Late Modernity, which is considered to be fluid, contextualized, and never completely defined. To that end, I will tackle some tendencies of the process of configuration of identities based on the theoretical framework of Modernity at the beginning of this chapter, since Beck, Bauman, and Giddens have thematized the issue of modern identities in their works. Then, I will borrow heavily from the ideas of two French authors, namely Francoise Dubet and Claude Duber, who tackle identities from a nominalist and existentialist perspective by considering that "identity is not something that remains necessarily identical, but the result of a contingent "identification." ${ }^{\prime 4}$ The approach of these two sociologists allows for a deepening of the theoretical perspective on identities and operationalizing concepts.

\footnotetext{
${ }^{84}$ Claude Dubar, La Crisis de las identidades: La interpretación de una mutación (Barcelona: Ediciones Ballaterra, 2002), 11.
} 


\subsection{Identities in Late Modernity}

The three authors that theoretically frame our conception of Modernity—Beck, Bauman, and Giddens-, extensively discussed the issue of identities throughout their works. I will identify three tendencies drawn from the broader thought of these authors in order to state the theoretical perspectives I assume. In this section, each of these tendencies is supported by the thought of a different author. However, this is only a methodological option to order my presentation, and I do not mean that each characteristic univocally belongs to the author I am quoting. Indeed, the three tendencies that I develop here are found in the three authors, beyond their differences. Also, it should be mentioned that this section only addresses some points of the vast thought of these authors on identities since presenting a complete development of the problem in their works is a massive effort that falls outside the goals of this thesis.

Individualized Identities. For Beck, there is a dual consequence for individuals regarding the perception of global risks. On the one hand, risks are equalizers because they are perceived as collective and beyond the possibilities of individual actions. For example, he has argued that pollution, radiation, or smoke do not respect social boundaries. The grey areas are large and obscure, for the boundaries are ultimately nothing other than the boundary perceptions of individuals. ${ }^{85}$ Within such a process, the idea of corporate class identities dissolves since the threats are supranational and class independent. ${ }^{86}$ "Processes of individualization deprive class distinctions of their social

\footnotetext{
${ }^{85}$ Beck and Beck-Gernsheim, Individualization, 49.

${ }^{86}$ Ibid. 33-37.
} 
identity. Social groups lose their distinctive traits, both in terms of their selfunderstanding and in relation to other groups. ${ }^{97}$ On the other hand, the first law of global risk society is that "the risk of catastrophes haunts the poor." ${ }^{" 88}$ Going back to the example, climate change especially causes devastation in poor regions. This causes a structure of risk grounded in a new logic of power beyond class power: risk presupposes a decision, hence a decision maker, and hence a radical asymmetry. ${ }^{89}$

In such a context, the configuration of identities is absolutely individualized. In a world where global risk has become a central organizing category of both public and personal domains, the individual can only seek refuge by himself/herself. The certainty in former times offered by tradition and traditional institutions - such as state, family, school, and religion — declines before the globalization of risk. Fellowship of the classes has disappeared while vulnerability has globalized. The individual is the last boundary of responsibility for the sake of one's own and others' survival. "If globalization, detraditionalization, and individualization are analysed together, it becomes clear that the life of one's own is an experimental life" 90 and the configuration of one's own identity is an individualized task.

Constrainedly Produced Identities: “To put it in a nutshell, 'individualization' consist of transforming human 'identity' from a 'given' into a 'task' and charging the

\footnotetext{
${ }^{87}$ Ibid., 39.

${ }^{88}$ Beck, "Global Risk Society."

${ }^{89}$ Ibid.

${ }^{90}$ Beck and Beck-Gernsheim, Individualization, 26.
} 
actors with the responsibility for performing that has and for the consequences (also the side-effects) of their performance." 91 This task is performed in Liquid Modernity, which is governed by consumption. Bauman claims that the society of consumers is characterized by the lack of definition between the consumed object and the entity which consumes it. He calls this characteristic of the society of consumers the fetishism of subjectivity. In his words,

"Subjectivity" in the society of consumers, just as "commodity" in the society of producers, is (to use Bruno Latour's felicitous concept) a faitishe - a thoroughly human product elevated to the rank of superhuman authority through forgetting or rendering irrelevant its human, all too human origins, together with the string of human actions that led to its appearance and was the sine qua non condition of that appearance... In the case of subjectivity in the society of consumers, it is the turn of the buying and selling of the tokens deployed in the construction of identity - that allegedly public expression of the "self" which is in fact Jean Baudrillard's "simulacrum," substituting "representation" for what it is assumed to represent - to be effaced from the appearance of the final product. $^{92}$

In the society of consumers, nobody is able to become a subject if one has not previously become a product. The essence of the subject is to be salable and to become another element of the fetishism of subjectivity. ${ }^{93}$ These fetishized subjectivities, imbued by insecurity, fear of risk, and unpredictability, in becoming themselves salable products, choose what and how to sell. Therefore, the fetishized subjectivities turn to be produced identities.

\footnotetext{
${ }^{91}$ Bauman, Liquid Modernity, 31.

92 Bauman, Consuming Life, 14-15. (The author's emphasis.)

${ }^{93}$ In Ernesto Fiocchetto, “Forty-Five Minutes of Intense Connectivity," I evolve in the relationship between fetishized subjectivities, mediatized subjectivities, performed identities, and digital religion.
} 
The possibility to choose is increasingly widespread within the identity market in liquid societies. Bauman observes that individuals today have more options than ever before to construct identity as a self-product. Therefore, the construction of a durable identity that coheres over time and space becomes increasingly impossible. Societies have moved from a time where individuals consider themselves as pilgrims - in search of deeper meaning — to Liquid Modernity, where we act as tourists — in search of multiple but fleeting identities. ${ }^{94}$ "The world full of possibilities is like a buffet table set with mouth-watering dishes, too numerous for the keenest of eaters to hope to taste them all. The diners are consumers. $" 95$ In the symbolic market of identities, consumers are free to choose among what is available for them. However, they are not free to abstain from choosing. The only choice that is of the table is that of not choosing. In Liquid Modernity, consumers are constrained to produce their own identities.

Reflected Identities. Giddens claims that such a context implies the increase of social reflexivity. Before a panorama in which individuals experiment a loss of external stable points of reference, are the last boundary of responsibility, and are constrained to produce their identities, individuals have to explore by their own merits to reflexively construct identities. "The reflexivity of Modernity extends into the core of the self. Put in another way, in the context of a post-traditional order, the self becomes a reflexive

\footnotetext{
94 Ziymunt Bauman, "From Pilgrim to Tourist - or a Short History of Identity," in Questions of Cultural Identity, ed. Stuart Hall and Paul du Gay (Oxford, Thousand Oaks, New Delhi: Sage Publications, 2011), 18-36.

${ }^{95}$ Bauman, Liquid Modernity, 63. (The author's emphasis.)
} 
project." $" 96$ Therefore, self-identity is a modern project; it means the effort the individual makes to reflexively construct a personal narrative in order to understand himself/herself and to try to control her/his life and future before risk and uncertainty. In his words,

A person with a reasonably stable sense of self-identity has a feeling of biographical continuity which she is able to grasp reflexively and, to a greater or lesser degree, communicate to other people. ... The existential question of self-identity is bound up with the fragile nature of the biography which the individual 'supplies' about herself. A person's identity is not to be found in behavior, nor-important thought this is - in the reactions of others, but in the capacity to keep a particular narrative going. ${ }^{97}$

The self is seen as a reflexive project, for which the individual is responsible. It forms a trajectory of development from the past to the anticipated future balancing risks and opportunities. Therefore, the reflexivity of the self is continuous, as well as pervasive. At each moment, the individual is asked to conduct a self-interrogation in terms of what is happening. Those responses that the individual gives presumes a biographical narrative which takes the shape of lifestyle — an integrated set of practices which an individual embraces at each moment among the multiple available choices. ${ }^{98}$ All in all, "self-identity is not a distinctive trait, or even a collection of traits, possessed by the individual. It is the self as reflexively understood by the person in terms of her or his biography." $" 99$

\footnotetext{
${ }^{96}$ Giddens, Modernity and Self-Identity, 32. (The author's emphasis.)

${ }^{97}$ Ibid., 54. (The author's emphasis.)

${ }^{98}$ Ibid., 74-88.

${ }^{99}$ Ibid., 53. (The author's emphasis.)
} 


\subsection{Identities in Francoise Dubet's Sociology of Experience}

These tendencies described in the previous sections broadly depict the processes of the social configuration of identities in Late Modernity. The two authors that I address in this and the following section will evolve in the same processes, but the contribution they make to the objectives of this work is twofold. While they elaborate on some other particular aspects of such processes, they offer a methodological framework that allows operationalization of the notion of identities for analysis purposes.

Francois Dubet wrote his Sociology of Experience as an alternative theory to his teacher and friend Alain Touraine's sociology of action. He proposes his theory as a middle ground between macro-sociologies - theories that try to explain the individuals and their actions based on social structures - and micro-sociologies - theories that tend to show the influence of individual actions on macro-structures. Therefore, he proposes the sociology of experience as a medium-range analysis tool based on the social experience of individuals. He claims that the individuals act under different rationalities and logics, which are never entirely reducible to the paradigm of a sole theory. Individuals reflect and act; theory has to be able to explain both their reflexivity and action. ${ }^{100}$ Hence, he calls "social experience to the more or less stable crystallization in the individuals and groups of different and sometimes opposed logics of action, which actors must combine and give hierarchy in order to constitute themselves as subjects."

\footnotetext{
${ }^{100}$ Francoise Dubet, La experiencia sociológica (Barcelona: Editorial Gedisa, 2011), 117.

${ }^{101}$ Francoise Dubet, Sociología de la experiencia (Madrid: Editorial Complutense, 2010), 160. (My translation.)
} 
In order to combine and give hierarchy to the logics of action, Dubet explains that the notion of experience implies three interpretative forms. In the first sense, experience connotes a way to be. The individual interprets this way to be both by discovering his/her subjectivity as a mysterious, irrational, and emotional individual within society and by constructing and modifying reality through a cognitive action. In the second sense, experience is defined by social relationships that make action meaningful and lead the individual to assign a status to the others. In fact, action is at the same time a subjective orientation and a social relation. This means that these two heterogeneous interpretative forms are constantly crisscrossing. Therefore, the third interpretative form implies that individuals autonomously produce a subjective distance with the system in order to explain, justify, and re-explain his/her experience since she/he is its author.

To put it simply, there are three traditional questions regarding identity that synthesize Duber's perspective about what a social experience is. The first interpretative form is implied in the question (a) "Who am I?" The second sense involves the question (b) "How am I related to others?" The third form denotes the individual's stance toward the two previous forms and can be summarized in the question (c) "What are the stakes in those relationships?" The answers to each question express different critical perspective regarding identity; each takes a critical position towards the other two; and all of them "claim that they can reconstruct society as a whole form a single central point." Thus, (a) self-definition, (b) relationship with others, and (c) stakes of relationships are both methods of descriptions by researchers and, most important, perspectives and logics that 
are used by individuals to organize the narratives of their experiences according to three logics of action. ${ }^{102}$

Integration Logic refers to the mechanisms that individuals use to integrate into the social system: (a) Self-definition is the subjective aspect of system integration. During infancy, “individuals internalize other's expectations, roles, and status that are enforced to the individuals or that they have acquired. For instance, when this identity involves language, nationality, gender, religion, and social class, identity is "a social attribute;" it is something "given" that compose identity. ${ }^{103}$ (b) Relationships with others are based on a conflict between "them" and "us," and others are defined by differences and heterogeneity. ${ }^{104}$ (c) Stakes of relationships, lastly, imply identification through collective values and norms. Individuals interpret culture as a series of values that guarantee order and identity together. ${ }^{105}$ This logic constitutes a kind of rationality that defines identity by belongingness to a group and difference from the others, and allow individuals pinpointing social relations and behavior inside normality—values and norms socially proposed and imposed.

Strategy Logic refers to mechanisms of instrumental rationality. Identity is configured and used as a resource to reach a status: (a) Self-definition is something that individuals possess and use according to their own strategies to pursue several goals. ${ }^{106}$

\footnotetext{
102 Dubet, La experiencia sociológica, 111.

103 Ibid., 112-13.

${ }^{104}$ Ibid., 113-15.

105 Ibid., 115-17.

${ }^{106}$ Ibid., 119-21.
} 
(b) Relationships with others are defined by competition and alliances within a social group that is perceived as a market. Individuals need to emphasize interaction since, in order to create their own benefits, they have to use their strategies before allies and opponents. Therefore, (c) stakes of relationships entail that each individual acts as a strategist who searches for power to optimize his or her resources and achieve goals. Consequently, social relations are spaces of concurrence, competition, alliances, rivalries, and individual and collective interests within a society where resources-money, power, dignity, influence, and acknowledgment—are scarce. ${ }^{107}$

Subjectivation Logic is a mechanism that individuals use to resist against integration logic and strategy logic: (a) Self-definition emerges as a commitment or engagement to various cultural models that form the subject's expression. No one lives as a subject, but at the same time, no actor is reduced to merely the self or other's interests. Individuals put into perspective the social order they learned with a capacity of conviction, critic, and action that is autonomous and that allows them to become subjects. ${ }^{108}$ (b) Social relationships with others turn to be an obstacle to this perception of subjectivation. Therefore, social conflicts are not considered only struggles for the protection of roles, values, and norms or only competition among rivals to optimize resources. They are a venue to remove obstacles and conflicts that could undermine the subject's recognition and expression. For instance, according to Dubet, a social movement is resistance to a church established by a religious society in the name of faith,

\footnotetext{
${ }^{107}$ Ibid., 122-24.

${ }^{108}$ Ibid., 124-30.
} 
opposition to tradition in a bourgeois world in the name of reason, or resistance to exploitation in an industrial society in the name of creative work. ${ }^{109}$ Lastly, regarding the (c) stakes of relationships, individuals self-present as critical subjects that oppose a society defined by systems of production and control and they produce their own historical definitions and narratives. They try to avoid alienation, that is to say, a loss of meaning and a loss of autonomy that emerge as a result of domination. The system might reduce the actor to a bearer of a role. ${ }^{110}$

Dubet claims that the individuals make their experiences at multiple and incongruent registers. Here, the possibility of autonomy appears. Social experience is constructed critically in the intersection of rationalization, instrumentalization, and subjectivation. Although Dubet differentiates of the three logics, he does not mean superiority of any of them in particular. These three logics are actually simultaneously equivalent to the individuals: "From the actor's perspective, there is not such a thing as a main point, so the banal debate is endless. Actors adopt all the perspectives in turn."111 On this basis, the individuals engage in the task of articulating these logics in narratives. They alternatively give superiority to one logic in their narratives, but this does not mean that the others are less important in the whole scene. Indeed, the alternative emphasis in one logic stimulates reflection on the others. Hence, the process of socialization is never complete.

\footnotetext{
${ }^{109}$ Ibid., 130-32.

${ }^{110}$ Ibid., 132-33.

${ }^{111}$ Ibid., 134. (My translation)
} 
Table 2.1 organizes the three logics and synthesizes their descriptors:

Table 2.1: Identity Descriptors and the Logic of Integration, Logic of Strategy, and Logic of Subjectivation according to Francoise Dubet's Sociology of Experience.

\begin{tabular}{|c|c|c|}
\hline & $\begin{array}{c}\text { PERSPECTIVES } \\
\text { REGARDING IDENTITY }\end{array}$ & $\begin{array}{c}\text { IDENTITY } \\
\text { DESCRIPTORS }\end{array}$ \\
\hline \multirow{3}{*}{ 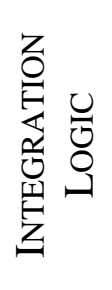 } & Self-definition & $\begin{array}{l}\text { Subjective integration into the system } \\
\text { Social Attribute (role) }\end{array}$ \\
\hline & Relationships & $\begin{array}{l}\text { We / Them } \\
\text { Differences and heterogeneity }\end{array}$ \\
\hline & Stakes & $\begin{array}{l}\text { Normality: Collective values and norms (socially } \\
\text { proposed or imposed) }\end{array}$ \\
\hline \multirow{3}{*}{ 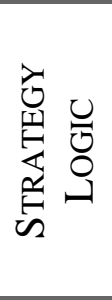 } & Self-definition & $\begin{array}{l}\text { Resources, strategies } \\
\text { Status tied to opportunities }\end{array}$ \\
\hline & Relationships & $\begin{array}{l}\text { Competition and alliances } \\
\text { Interaction to create the individuals' own benefits }\end{array}$ \\
\hline & Stakes & $\begin{array}{l}\text { Power } \\
\text { Strategies to optimize resources }\end{array}$ \\
\hline \multirow{3}{*}{ 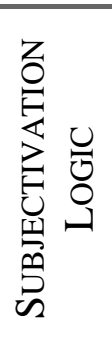 } & Self-definition & $\begin{array}{l}\text { Commitment, engagement } \\
\text { Putting into perspective the social order } \\
\text { Autonomy }\end{array}$ \\
\hline & Relationships & $\begin{array}{l}\text { Venue to remove obstacles to subjects' } \\
\text { recognition and expression }\end{array}$ \\
\hline & Stakes & $\begin{array}{l}\text { Subjects' historical definitions and narratives } \\
\text { Avoiding alienation }\end{array}$ \\
\hline
\end{tabular}

Note: My elaboration based on Francoise Dubet, Sociología de la experiencia (Madrid: Editorial Complutense, 2010), 134.

\subsection{Claude Dubar and the Crisis of Identities}

The French sociologist Claude Dubar is a prolific writer who has been highly influential in Europe. Besides, his contributions on identities, occupational trajectories, labor insertion of young people, professional training, the sociology of the professions, and the 
sociology of education have had a direct impact on social research in Latin America for the last three decades. ${ }^{112}$

After rejecting the existence of essential belongings and specific differences, he starts his work The Crisis of Identities: The Interpretation of a Mutation claiming that "there are only modes of identification that are variable along the course of collective and individual history". ${ }^{113}$ Moreover, identification is the result of a double linguistic operation: differentiation and generalization. The first defines the singularity of an individual in relation to the others. Thus, "identity is difference." 114 The latter defines a common bond to a particular set of elements shared with others. Thus, "identity is common belonging." ${ }^{115}$ These two operations are at the base of the paradox of identities: what is unique is what is shared. ${ }^{116}$ Consequently, the paradox cannot be solved unless we take the common element of both operations into account, that is to say, the identification of and by the other. In a few words, "there is no identity without

\footnotetext{
${ }^{112}$ In Ernesto Fiocchetto and Azucena Reyes Suárez, “Aportes sobre el concepto de 'identidad' en la Sociología de la Religión.” MILLCAYAC - Revista Digital de Ciencias Sociales 3, no5 (2016), 133-152. http://revistas.uncu.edu.ar/ojs/index.php/millca-digital/article/view/765/473, we evolve on the development over the concept of identity in the Sociology of Religion based on Claude Dubar's perspective. This article was the base for further personal studies on Dubar. Consequently, part of this section is inspired in the article I co-authored with Azucena Reyes but it goes further on the analysis.

${ }^{113}$ Claude Dubar, La crisis de las identidades: La interpretación de una mutación, (Barcelona: Ediciones Ballaterra, 2002), 12. (My translation)

${ }^{114}$ Ibid. (My translation)

${ }^{115}$ Ibid. (My translation)

${ }^{116}$ Ibid.
} 
otherness," ${ }^{117}$ and both identities and otherness vary historically and depend on their context.

Therefore, Dubar distinguishes two kinds of identity forms: identities for others, which others attribute to the individual; and identities for oneself, which are claimed by the individual herself/himself. One can self-identify by accepting or refusing the identities for others. Both kinds of identity forms can coincide or not. Thus, he states the first thesis of his book: "There is a historical movement, at the same time very old and very uncertain, from one kind of identity form to the other. More particularly, there are historical processes, at the same time collective and individual, that modify the configuration of the identity forms." ${ }^{118}$ Within this historical movement, Dubar rescues two particular processes that describe two typical social forms, namely community forms and societal forms.

Community forms are identity forms that suppose aggrupation of individuals in communities that are considered as systems that are pre-assigned to individuals and reproduce themselves identically, generation after generation. In such communities, each individual has a primordial belonging that defines himself/herself as a member with preassigned roles. These forms depend closely on the belief in the essential belonging to certain groups that are considered pristine, immutable, or vital to ensure the individual's existence. Thus, the groups of belonging turn to be essential sources of identities. These identity forms persist in modern societies and can be for oneself or for others. Further

\footnotetext{
${ }^{117}$ Ibid. (My translation)

118 Ibid., 12-13 (My translation)
} 
example of them is the identity forms of ethnicity, nationality, religion, or corporations. ${ }^{119}$

Societal forms emerge as multiple, variable, and ephemeral groups that individuals join by limited periods and provide identity resources provisionally. Each individual possesses multiple belongings that can vary along her/his life. These identity forms are closely related to the belief in the primacy of the individual over the collective belongings. Personal identity is the result of personal elections-not something inherited-, and it conditions the societal identification of individuals in different groups, such us familiar, professional, religious, or politic groups. Here again, these identity forms can be for oneself or for others.

Moving forward, Dubar elaborates on a space-time categorization of both identity forms. On the one hand, he observes that identifications for others are based on forms of spatialization of the social relations that he will denominate axis of relation. This axis recovers social institutions as sources of socialization since such institutions socialize forms of symbols and meanings that tend to define the individual's identity. On the other hand, identifications for oneself involve temporalization forms that he names biographical axis. This axis comprises the individual's life itself in its temporal development. It includes from what they inherited to what they constructed by themselves based on their expectations and possibilities. Both axes combines to define

119 Ibid., 13. 
identity forms, that is to say, social forms of identification of individuals in relation with the others along their whole lives. ${ }^{120}$

As a result, identity is constructed in the always complex articulation that is the intersection between both identity forms - for oneself and for others — and both axis - of relation and biographical. For instance, this intersection might imply what is inherited from the previous generation at a familiar level, plus the institutional strategies of the church that the individual belongs to, plus the rejections, resignifications, acceptances, and choices that the individual does throughout her/his life.

Dubar claims that this path from a community form to a societal form or from an identification for others to an identification for oneself constitutes a crisis of identities. Such a crisis implies that the individuals have triggered two heterogeneous yet articulated identity processes. A crisis of identities is a permanent negotiation between individuals who demand identities — identities for others given through an act of attribution — and offer identities — identities for oneself legitimated by acts of belonging. This identity negotiation implies a complex communicative process based on two kinds of identity strategies: objective transactions on the relational axis that the individuals use to interact in institutionalized contexts; and subjective transactions on the biographical axis that confront the individual against himself/herself when she or he faces the conflict between inherited identities and expected identities.

In sum, Dubar suggests that "identity is nothing else but a result simultaneously stable and provisional, individual and collective, subjective and objective, biographical

\footnotetext{
${ }^{120}$ Ibid., 18-20.
} 
and structured, of diverse processes of socialization which at the same time construct the individuals and define the institutions." "121 In his analysis of Dubar's definition, Bauman notes an interesting point. He observes that socialization itself is not a one-directional process, but "the complex and unstable product of an ongoing interplay between the yearning for the individual freedom of self-creation and the equally strong desire for security that only the stamp of social approval, countersigned by a community (or communities) of reference, can offer." ${ }^{122}$ It is in this interplay that the individuals' identities are constructed and institutions — and societies — are defined, strengthened, weakened, or modified. In brief, both individuals and societies mutate throughout the crisis of identities.

In closing, Dubar elaborates on four typical combinations of the identity forms for oneself and for others, and the relational and biographical axes. These types result form possible transactions that the individuals do as they use their identity strategies when negotiating their identities.

a. The biographic for others form is communitarian and represents the individuals' belonging to a local group and an inherited culture. This type implies a nominal self that survives when there is a preeminence of $u s$ over me. Dubar names this type cultural identity, and it compresses language, beliefs, traditions, and generational

\footnotetext{
${ }^{121}$ Claude Dubar, La Socialisation: Construction des identités sociales et professionelles, (Paris: Armand Colin, 2003), 108-109, quoted in Zygmunt Bauman, "Migration and identities in the globalized world," Philosophy and Social Criticism 37, no. 4 (2011): 433. DOI: 10.1177/0191453710396809

${ }^{122}$ Bauman, "Migration and identities": 433.
} 
lineage. Perhaps, the clearest example is the last name that is inherited from the parents. $^{123}$

b. The relational for others form is societal and compress the interactions within a system of institutions and hierarchies. This type implies a socialized self that assumes roles and positions. Dubar names this type status identity, and it denotes the multiple statuses and roles available in modern societies. A good example of this type is the profession that individuals use to introduce themselves. ${ }^{124}$

c. The relational for oneself form is the result of a reflexive consciousness that work out a commitment or engagement. Such commitment, on the one hand, has a subjective meaning, and on the other, implies identification with a group of belonging that shares the very same project. This type implies a reflexive self that shows the chosen self's face to the meaningful others. Dubar names this type reflexive identity, and it indicates the unity of the self and his/her discursive capacity to give arguments in support of a claimed and unifying identity. For example, it is the commitment in a political movement chosen with conviction. ${ }^{125}$

d. The biographic for oneself form entails putting into perspective the assigned identities and the elaboration of a life project. This type implies a narrative self who tells a story about itself, about what the self is and wants to become. Here, the self searches recognition not only by the meaningful others but by the generalized others as well. It

\footnotetext{
${ }^{123}$ Claude Dubar, La crisis de las identidades, 66-67.

${ }^{124}$ Ibid., 67.

${ }^{125}$ Ibid., 67-68.
} 
denotes a biographic process with crises and search of authenticity. Dubar names this type narrative identity, and it compresses the continuity of a self that is projected in consecutive belongings, perturbed by external changes, and rocked by disruptive existence. ${ }^{126}$

Table 2.2 organizes the four typical combinations:

Table 2.2: Typical combinations of the identity forms "for oneself" and "for others," and the relational and biographical axes by Claude Dubar.

\begin{tabular}{|c|c|c|}
\hline & IDENTITY FOR OTHERS & IDENTITY FOR ONESELF \\
\hline \multirow{3}{*}{ 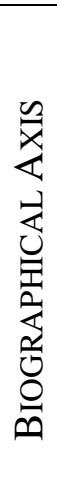 } & Cultural Identity & Narrative Identity \\
\hline & $\begin{array}{l}\text { - Communitarian } \\
\text { - Belonging to a local group and an } \\
\text { inherited culture } \\
\text { - Preeminence of Us over Me }\end{array}$ & $\begin{array}{l}\text { - Putting into perspective assigned } \\
\text { identities } \\
\text { - Elaborating a life project } \\
\text { - It is the self's story about itself } \\
\text { - Biographical process and search of } \\
\text { authenticity }\end{array}$ \\
\hline & Nominal Self & Narrative Self \\
\hline \multirow{3}{*}{ 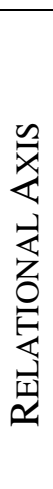 } & Status Identity & Reflexive Identity \\
\hline & $\begin{array}{l}\text { - Societal } \\
\text { - Interactions within a system of } \\
\text { institutions and hierarchies. } \\
\text { - Roles and positions. }\end{array}$ & $\begin{array}{l}\text { - Reflected commitment } \\
\text { - Subjective meaning and } \\
\text { identification with a group } \\
\text { - Discursive capacity to give } \\
\text { arguments in support of a claimed and } \\
\text { unifying identity }\end{array}$ \\
\hline & Socialized Self & Reflexive Self \\
\hline
\end{tabular}

Note: My elaboration based on Claude Dubar, La crisis de las identidades: La interpretación de una mutación, (Barcelona: Ediciones Ballaterra, 2002)

${ }^{126}$ Ibid., 68. 


\section{CHAPTER 3: Configuring Religious Identities in a Migratory Context. The Experience of South American Christian Millennial Migrants in Miami}

When we arrived in Miami, I was just another person in the crowd. I didn't have anything that makes me feel that I belonged here. I needed to take roots and religion helped us. Through religion and the community in which we live our faith now, I transferred all the things that I had there... Now, I feel I belong here. ${ }^{1}$

One of the participants said these words during the last focus group session I conducted. I read this paragraph several times. In a moment, I realized that it contained many of the words and ideas that I was analyzing in the transcripts of the interviews and focus groups sessions. This millennial migrant's voice speaks about a path from there (the voice's country of origin) to here (Miami). Such a movement links a present (now) to a past (I had). The voice discloses processes, feelings, faith, belongings, and community bonds. The voice speaks about roots: roots that remember how they were uprooted from former soil; roots that need a new soil for rerooting. At that moment, I comprehended that the living ground of the young believers' shared experiences was offering me a meaningful semantic field to construct a thorough contribution to the research problem.

The purpose of this chapter is to develop the findings of the two research questions that inspired this research. The South American millennial migrants' process of configuration of religious identities in Miami and the relationships they establish with religious institutions will be tackled from the perspective of migrants' uprooting and rerooting, here and there, now and then. The ground of their voices, together with the

\footnotetext{
${ }^{1}$ Focus Group 02, session conducted by Ernesto Fiocchetto, December 2019, transcript. (My emphasis.)
} 
contextual ground - Chapter One - and the theoretical ground - Chapter Two- , is the base of my understanding, answers, and contributions.

The first section is pivotal for the rest of the chapter and, therefore, for this study. There, I define the process of migrants' religious identity configuration. This definition informs the rest of the material. Then, the analysis focuses on such a process in the context of Late Modernity according to the interviews and focus groups in which South American millennial migrants in Miami participated. Lastly, the two main consequences of the notion of secularism that Hervieu-Léger explains in her works, namely individuation of beliefs and religious deinstitutionalization, are critically addressed from the perspective of the participants in this research. In this way, I offer a contribution that is limited to the contexts addressed in this research but can potentially shed light on others experiences in similar contexts in which believers are configuring their religious identities in the vast religious landscapes of Late Modernity.

\section{Defining Migrants' Processes of Religious Identity Configuration}

Interviewer: Can you introduce yourself, please?

Interviewee: $\mathrm{I}$ am + a name.

I am from + a South American country.

I came in Miami + a year.

This dialogue more or less was repeated once and again at the beginning of every single interview and focus group session I conducted. It is logical. There is no novelty in answers like these coming from South American millennials who have migrated to Miami and have gently accepted the invitation to participate in a study on religious identities of young migrants from the southern continent. However, this repetitive and 
straightforward personal introduction reveals a dynamic. The three phrases that our interviewees chose to present themselves allude to a here (Miami) and a there (a South American country), and to a now (I am) and a then (I came). The identity configuration of a migrant consists of a spatial-temporal process of delocalization and relocalization that I call uprooting and rerooting. Therefore, such a process is always critical —in the sense of Dubar's crisis of identities - that is to say, a permanent negotiation between individuals who demand and offer identities within a spatial-temporal context.

The spatial-temporal context I refer to-here/there, now/then-does not suppose a radical break. For our migrants' lives, part of the theres and the thens are rerooted here in Miami and now in 2018/2019. While they speak, they share past hopes and expectations before present achievements and frustrations, past despairs and risks before present solutions and worries, past needs and desires before present satisfactions and disappointments. Migration both is caused by and is a source of hopes, desires, expectations, uncertainties, instabilities, and risks. These causes and consequences of the migratory process are not only the result of a psycho-emotional situation; rather, they are framed in the broader movement of Late Modernity. Consequently, our millennial migrants' narratives exemplify how migration triggers the modern tendencies of the configuration of identities that Beck, Bauman, and Giddens disclosed.

In this uprooting and rerooting process, religion plays a role. Following Danièle Hervieu-Léger's definition, religion implies a way of believing that is rooted in an authoritative tradition. ${ }^{2}$ Such a way of believing implies making memory of the

\footnotetext{
${ }^{2}$ Danièle Hervieu-Léger, Religion as a Chain of Memory (New Brunswick, N.J.: Rurgers University Press,
} 2000), 82 . 
traditional chain of beliefs - convictions that owe their validity to the meaning and coherence that give to the subjective experience of those who hold them ${ }^{3}$ - within one believes. In the context of modern secularization, this chain of memory entails individuation of beliefs, deinstitutionalization processes, homogenization, motion, and niches.

Putting everything together, I consider that the migrant's religious identity configuration consists of a continuous spatial-temporal process of uprooting and rerooting, in which a memory rooted in an authoritative religious tradition triggers beliefs that are meaningful for the migrant's self-understanding. ${ }^{4}$

\section{Uprooting and Rerooting in Late Modernity}

In reference to the perspectives of Beck, Bauman, and Giddens, now with HervieuLéger's notion of religion in mind, the interviewed millennials embody the three tendencies that I drew from the authors of Late Modernity. First, in the global risk societies, the configuration of identities is an individual task. Second, in the society of consumers, subjectivities are fetishized, and identities are constrainedly produced within

\footnotetext{
${ }^{3}$ Ibid., 72.

${ }^{4}$ At this point, I want to draw attention to a difference between my perspective and Thomas Tweed's contribution in his book Crossing and Dwelling: A Theory of Religion, (Cambridge, Massachusetts, and London: Harvard University Press, 2008, Kindle Edition). He argues that religions are "confluences of organic-cultural flows that intensify joy and confront suffering by drawing on human and suprahuman forces to make homes and cross boundaries" (Loc. 1730-31 of 3162). From my perspective, dwelling and crossing are not essential to a definition of religion but a common factor to all the cultural dimensions in Late Modernity. Modernity is fluid, and therefore, modern religion is fluid. My point is to understand what the role of religion as a chain of memory in migrants' crossing and dwelling (uprooting and rerooting) is in the context of a mobile Modernity.
} 
a vast symbol market. Third, in Late Modernity, the self becomes a reflexive project and self-identities implies the understanding of the self in terms of the individual's biography.

In the interviews and focus group sessions, the individuals' narratives extensively elaborate on their experiences of uprooting and rerooting from there to here bringing aspects of a then that is now meaningful. These narratives involve and concretely depict the three tendencies in the particular contexts of South American millennial migrants and believers biographies. Drawing from their migrant and religious journeys, we can ground the theory to disclose new aspects and contributions.

\subsection{Risks There and Here: Cultural Matrix and New Soils for Meaningful Roots}

Ulrich Beck asserts that in a world where global risk has become a central organizing category of both public and personal domains, individuals can only seek refuge by themselves because they are the last boundary of social, political, and economic action. As seen in the first chapter, the reasons for emigration of South Americans are, almost exclusively, related to the search for better living conditions due to the socio-politicoeconomic instability suffered in the subcontinent during the last three decades. The interviewees in this study are not an exception.

The crisis of 2001 (in Argentina) destroyed us. We had a very good economic status, and my father lost everything in a couple of months. They decided to sell everything there and we took a plane to make a new start here. ${ }^{5}$

We didn't have a bad life in Ecuador. But it was dangerous. And ten years ago, it was more dangerous than it is today. Moreover,

\footnotetext{
${ }^{5}$ Interview 03, interview by Ernesto Fiocchetto, December 2018, transcript.
} 
the opportunities to grow are less. In South America, everything takes more time. ${ }^{6}$

Avoiding the uncertain fate in their home countries, all the interviewees migrated with the hope of a better lifestyle. Those who migrated during the nineties remember the decision made by their parents when they were kids or teenagers; those who migrated in the new millennium, more crudely experienced the burden of the individual decision to leave many things (or everything) behind and make a new start in a place where possibilities seemed better. All of them remember the sorrow of uprooting: family, home, school, job, love... everything is gone. The original situation of a migrant is always full of uncertainties and risks that they try to evade by uprooting.

Regarding their arrival in Miami, they narrated two different situations. Such a difference depends on whether a group (family, friends, or work) received them or not. One of the interviewees told his own experience compared against his wife's. Under the same roof, the situations were completely dissimilar.

I arrived and, during the first week, I started to hang out with my work group. Every Saturdays we played soccer, and we ate asado on Wednesdays. But that wasn't what happened to my wife. I always compare both experiences. She was alone. She knew nobody. It took her a little longer to build relationships here. ${ }^{7}$

For many of them, once they have arrived in Miami, the American Dream is not as easy as they dreamed. All of them characterize their first impressions of the city with similar words: "Miami is huge," and "relationships in Miami are not easy." These millennial migrants are searchers for better living conditions in a city of searchers. They

\footnotetext{
${ }^{6}$ Interview 04, interview by Ernesto Fiocchetto, December 2019, transcript.

${ }^{7}$ Interview 06, interview by Ernesto Fiocchetto, December 2019, transcript.
} 
are a little set of expectations inside a whole ocean of expectations. There are too many competitors.

The above description is not necessarily related to the labor market. In fact, according to the characteristics of the South American millennial migrants developed in the first chapter, these young people had a baggage that allows them to compete successfully for a job or a school and for regularizing their economic and legal situation through different strategies with more or less individual effort. The field of relationships, however, was much more complex. The prevailing feeling for them was loneliness. In those first moments as South American millennials who had just migrated, the big and crowded Miami was for them the city of loneliness. Moreover loneliness, in several cases, is also related to new risks. One of the interviewed millennial men said:

I had two options. Either I stayed alone in the room I rented, or I accepted the rules that Miami has set for a young migrant. The U.S. opens doors for many negative stuff: drugs, worldly pleasures, crimes, illegal businesses, prostitution... Everything was there. They offered those businesses to me openly. [...] I was afraid many times here. I didn't want to choose the wrong way. The price for that was loneliness. And in some moments, I had up to three jobs to survive. ${ }^{8}$

Another woman remembered that she stayed for three months "locked in her room" during the weekends. She looked forward going to work on Mondays, because she was completely alone during her free days. She considered that the options for socializing were "risky," and

\footnotetext{
${ }^{8}$ Interview 04.
} 
dangerous for me. You know... drugs, alcohol, men, parties... [...]

It would have been easier to earn money and avoid feeling alone, but I din't want that for my life. ${ }^{9}$

Those who were received by relatives or friends had a little better experience, though some of them expressed that, after a while, the relationships turned difficult.

Above and beyond the familiar particularities, the sorrow of uprooting or the risk of (not) rerooting resulted in loneliness. They were alone. They realized that they were the last boundary of responsibility for the sake of their own survival. They faced the individualized task of becoming an immigrant millennial from South American in Miami.

For many of them, religion begins playing a role in this very situation as a pivotal part of their cultural identity. Christianity, and more specifically Catholicism, is a cultural matrix for South American beyond their religious practices. It is a social habitus that shapes the wrap of the societies of origin of these millennial migrants. Following Dubar, the biographical axis of their identities is, consequently, configured over this ChristianCatholic matrix. This fact has consequences in the identity process of the interviewees. For some of them, religion offers a set of values and moral references that guided their behavior.

I was alone for a long time when I arrived in this country. [...] I was living alone in an efficiency. [...] I thought, "Should I go back? Should I stay here?" The only thing I could do is to pray "God: Lord, make me strong enough not to go back emptyhanded." Because I came here with many dreams and plans. [...] I had broken up with my boyfriend and I wanted to be with my mom, my dad... Loneliness, hopelessness... I was desperate... Due to my faith and due to mi principles I din't make the decision to go out with people that invited me. If I had gotten involved with them, I would have finished different, I would have ended up

\footnotetext{
${ }^{9}$ Interview 05, interview by Ernesto Fiocchetto, December 2019, transcript.
} 
drinking too much, partying, being with men... well, Miami would have conquered me. ${ }^{10}$

The risks of Miami are confronted against the safety offered by an inherited ChristianCatholic culture. In some cases, they did not practice the religion but religion was there as a cultural matrix. When trying to reroot their existences in new soil, they discovered that some roots from the old soil were meaningful for them within a risk society. However, paraphrasing one of them, the price for the safety of those roots from the old soil was loneliness.

At this point, they went a step further in their narratives and considered that religion was also a significant factor for rerooting in the new soil. The cultural matrix that offered safety and certainty there is reenacted here in small communities that received them. There are new soils for those meaningful roots. Christian communities in Miami are the new soil that embodied the living lineage of belief that reinforced the Christian religious memory in which the young immigrants find the safety and certainty of the old wrap that protects them. In the narrative of their search, they describe different kinds of religious communities, but they chose those that they felt that were open, close, and friendly. They do not refer to the entire institution or tradition-Catholicism, Protestantism, Pentecostalism, etcetera-but they speak about these particular community, parish, group, or assembly that turn into "my" community, "my" parish, "my" group, or "my" assembly.

I feel like family. Since I arrived, I felt that it was a family. I felt I was somebody there. I felt that they cared about me. (She told a particular situation that led her living by herself, and continued.) I

\footnotetext{
10 Ibid.
} 
was alone again. But now there was a group of boys and girls of the church who were with me. [...] They worried about me. ${ }^{11}$

The migrants' biographical axis, therefore, experiences an individualized transition from the identification for others to the identification for oneself. In terms of religion, the nominal self (I am Christian because I inherited Christianity) happens to be a narrative self (I choose to be a Christian as a strategy for elaborating my life project here in Miami). Thus, these millennial believers resignify the memory rooted in the authoritative tradition of their countries in South American as a cultural matrix and integrate it into the self's story about themselves. The young migrants claimed the inherited South American Christian identity as a socialization element. At the same time, the face of the risky and dangerous metropolis starts to change into the new soil where the migrant millennial believer can enroot. The huge city is also the city of "my" small group of reference.

\subsection{An Individual Task: Fitting in the Religious Market of Miami}

Individualization is at the base of the process of the configuration of religious identities of these young migrants in many aspects. Paraphrasing Zygmunt Bauman, the given cultural religious identity they inherited in South America is resignified as an individual task. ${ }^{12}$ The process described above shows how this task supposes the responsibility of the believer, especially for migrants, who change their given cultural environment. If they

\footnotetext{
${ }^{11}$ Interview 01, interview by Ernesto Fiocchetto, December 2018, transcript.

${ }^{12}$ Zygmunt Bauman, Liquid Modernity (Cambridge: Polity Press; Massachusetts: Blackwell, 2000), 31.
} 
want to enroot in the new soil, they have to negotiate the way. At least, they had the task of unlocking the room of loneliness and searching for a community where they fit.

I felt I didn't fit in Miami but, when I discovered the church, I also discovered that I was not the only one with such a feeling and that helped me fit here. ${ }^{13}$

In the huge city, the religious market is huge too. The first chapter showed the diverse religious market in Miami, especially within the Christian tradition. In this society of religious consumers and providers, the young millennials experienced two movements. Fitting in the huge Miami through the small community implies a negotiation in which they both become salable for a community and choose what and how to sell.

The first movement implies, on the one hand, that they experienced rejection in some communities because, for other already rerooted migrants, a new migrant means more competition.

I went to another church for two years and nobody came up to me. I tried to join a prayer group but I was not welcomed. They knew each other for a while. They were very closed. I was a stranger there. ${ }^{14}$

Therefore, some communities close themselves off and try to keep the security and certainty that they had been searching and, indeed, found. Hence, the process is not only about purchasing the right Christian product; rather, it is about communities that purchase the right migrant believers. Millennial migrants fetishized their religious subjectivities in order to become a saleable religious product themselves.

\footnotetext{
${ }^{13}$ Focus Group 01, session conducted by Ernesto Fiocchetto, December 2018, transcript.

${ }^{14}$ Interview 02, interview by Ernesto Fiocchetto, December 2018, transcript.
} 
Well, you also have to adapt if you want to fit. There were things that I was not used to doing, but I tried to do them. ${ }^{15}$

On the other hand, it entails that they, being migrants in Miami, are also religious migrants who cross from one church to the other, many times, until they find the one where they fit.

I visited many churches, many Cristian churches. Protestants, Pentecostals, Catholics... I went to all the churches I could go. I felt lonely and I thought a church would help me a lot. I even thought about going to other religions, but I never went. And then, I met a guy from my country, and he invited me to what now is church. I found the place. I felt home there and I'm still part of this community. ${ }^{16}$

As Hervieu-Léger noted, this religious migration is facilitated by a situation in which denominational and community boundaries are less and less important, and there is no social cost in the path from one to the other, especially in the situation of these newly arrived migrants. Thereupon, their need for community niches is clear. In the huge city of Miami, they need the minima of certainty offered by "my" community.

The second movement shows how vast the possibilities are to choose within the diverse religious landscape in Miami.

Luckily, here in Miami, you have hundreds of options and communities where you can go. If you don't like this one, you can go to the next one. ${ }^{17}$

These migrants are in need of consuming a Christian identity, and the Miamian symbolic market of identity is vast. If they want to fit, they have to choose. For not choosing means

\footnotetext{
15 Interview 02.

${ }^{16}$ Interview 07, interview by Ernesto Fiocchetto, December 2019, transcript.

${ }^{17}$ Interview 01.
} 
not fitting, and therefore, they would have needed to use a different strategy rather than configuring a meaningful religious identity. This option is valid and used by many migrants who reroot in the big city through some other strategies in other fields. However, focusing on the religious dimensions of a migrant identification process, the only choice that they do not have in the market is that of not choosing. In Miami, they felt constrained to make decisions to produce their own religious identities, that is to say, they had to choose what to buy and become salable themselves.

Dubar's conceptual frameworks help us synthesize this second tendency of modern religious identities. The spatial categorization of identities, namely the axis of relation, recovers social institutions as sources of socialization. In trying to reroot, the migrant millennials negotiate their socialized and reflexive selves. They migrate within a complex and diverse system of religious institutions. They interact with such institutions using different strategies. Under certain circumstances and for different reasons, they choose their group of belonging by giving a subjective meaning to the community they identify with. Some of them even consider committing in the chosen religious group. Others only interact with the group in their own benefit. All of them consider the possibility that a group can be an option for a young migrant from South America who wants to fit in Miami. Whether they configure a status identity for others or a reflexive identity for themselves, the spatial dimension of the configuration of their religious identities plays a role in rerooting their migrant existences in Miami. 


\subsection{Reflecting on their Identities: Making Meaningful Memory of Significant}

\section{Spaces and Times}

The two described tendencies imply individual responsibility throughout the process. In addition, they involve the development and use of identity strategies that are those of reflective action. Indeed, it is clear that for the young South American migrants who configure religious identities in Miami, the self becomes a reflexive project, to use Anthony Giddens' words. ${ }^{18}$

During the interviews and focus group sessions, they had to share their personal journeys with me, who was an unknown interviewer for them. Such a task led them to gradually become aware of the reflexive project by putting words to their experiences and elaborating on a narrative about their biographies. Throughout this exercise, they came and went from there to here and from then to now and vice versa in order to construct a biographical narrative about their current lifestyles. Ultimately, the base of their religious identity is not related to behavior, practices, or rituals, nor is related to the acceptance or the commandment of the others; rather, they elaborate on a reflexive project that makes sense of the special-temporal dimensions of their uprooting and rerooting. There is not such a thing as acritical acceptance, assumption, or heritage. They construct fleeting biographical narratives in which the religious is the result of a reflective project that is coherent now and then, here and there.

Religion as memory rooted in an authoritative tradition plays such a role since it triggers meaningful beliefs that are resignified in the present Miami-now/here-but are

\footnotetext{
${ }^{18}$ Anthony Giddens, Modernity and Self-Identity: Self and Society in the Late Modern Age (California: Stanford University Press, 1991), 32.
} 
rooted in the old country of origin — then/there. Some characters symbolize that meaningful past that helps make sense of the religious present: parents, relatives, groups of friends at the church, and religious leaders are some of them. Above all, the familiar context had a noticeable influence. When they made memory and tried to introduce themselves within a believing lineage, the thread of continuity among believers from generation to generation takes place firstly at home.

Religion starts with my family because I was raised in a Catholic family, and they taught me religious values. ${ }^{19}$

This woman's words in one of the interviews repeated once and again with slight changes in each migrant's narrative. While making their religious identity understandable for themselves, they reflected on a familiar chain of memory that can be depicted as HerviueLéger did: "as our fathers believed, and because they believed, we too believe." 20 In one of the focus group sessions, the reference to "grandmas" 21 was frequent and they were surprised about such a coincidence in a group formed by millennials from five different South American countries from the southern Argentina and Chile to the northern Colombia and Venezuela. They themselves rescued the role that womenmothers, grandmothers, aunts, mothers-in-law, godmothers-played as vehicles of religious traditions in the subcontinent during the chat. Indeed, in South America, the religious lineage tends to be institutionally masculinized — especially in the Catholic

\footnotetext{
${ }^{19}$ Focus Group 02.

${ }^{20}$ Hervieu-Léger, Religion as a Chain of Memory, 81.

${ }^{21}$ Focus Group 02. (The reference to the grandmothers were also present in Interview 01, 03, 04, 05, and 07.)
} 
Church, but also in Protestant denominations-, but historically it is traditionally feminized in everyday life. The transmission, teaching, and control of the collective memory rooted in a lineage of belief are in the hand of women in the households, and millennials' grandmothers played a prominent role in that regard.

I was raised a Catholic. My grandma transmitted the faith to the whole family. She transmitted the faith and her manners of believing. ${ }^{22}$

Rephrasing Heriveu-Léger, these millennial South American migrants emphasized the feminine figures in their reflexive projects because in the southern subcontinent, as our mothers and grandmothers believed, and because they believed, we too believe.

Irrespective of the present level of commitment in a religious group or the frequency of the religious practices, there are meaningful roots from those spaces and times that are meaningful for the configuration of their religious identities as a reflexive project. Further examples can be found in two extremes of the interviewees. On the one hand, a man in his thirties who "was not religious at all" when living in his country of origin but, after migrating, is highly committed to a church. On the other hand, another man in his thirties who regularly practiced his religion with his family and, after migrating, does not practice anymore. Both paths from one to the other level of religious practice is reflexively organized in their biographical narratives to take account of their situation. The strategies they use to that end are various: rational decisions they made at some moment, happy coincidences that led them to take part in a religious community, logical processes according to the age or familiar customs, and the recognition that

\footnotetext{
${ }^{22}$ Interview 05.
} 
now I don't go (to a church) but I know that I want to go, and I'm sure that eventually the desire or the need of going will make me go. ${ }^{23}$

Nonetheless, beyond the particularities of each narrative, the reflexive element is pivotal in the configuration and self-understanding of their religious identities. When they say "I am a Christian," whatever the denomination is, they evoke something reflected and projected. I do not mean that, at some point in their lives, they took particular time to reason about a coherent decision on how they would live religion. Such speculation, even when present in a couple of cases, is not what I mean when I refer to the reflexive project. In fact, if those particular times existed, they would be constantly challenged since, as Giddens noted, the reflexivity of the self is continuous, as well as pervasive.

When I was a child I did it (religious practices) without thinking, without any sense. But then, when I grew up and I started to go to the church, it is in that moment that I labeled myself as a Christian. I understood what that meant. I was baptized in the new church where I was going. I understood what I was doing and it was something true. And now, the older I get, the more I read, the more I make new questions, the more I understand, the more I know... I always try to find reasons for my beliefs and my practices. I can't do things without thinking anymore. I don't like it... regarding religion and also in the rest of my life. ${ }^{24}$

The point here is that they do not self-identify as religious by chance, or just because they inherited it. There is a religious memory rooted in an authoritative tradition that gives meaning to a set of reflexively selected beliefs and helps these South American millennial uproot and reroot in a continuous process of identity configuration through significant spaces and times. A reflexive project means the capacity to keep a particular

\footnotetext{
${ }^{23}$ Focus Group 02.

${ }^{24}$ Interview 02.
} 
narrative going. ${ }^{25}$ In the case of the configuration of religious identities, such a narrative finds its continuity in a memory rooted in a believing lineage and allows the migrant millennials to self-understand as Christians by a set of meaningful beliefs from there and here, now and then.

\section{Freelance Believers I: South American Millennial Migrants and the Process of Individuation of Beliefs in Miami}

Following Hervieu-Léger, the processes of the configuration of religious identities are set in the context of modern secularization. As developed in the second chapter, secularization is not the withdrawal of religion form societies, but the set of processes of readjustment of beliefs that is produced in societies whose engine is instability, uncertainty, and risk. The French sociologist claims that two main processes take place as a consequence of secularization in Western societies. They are individuation of beliefs and religious deinstitutionalization. ${ }^{26}$ Both processes have a common base. In Modernity, the legitimation of beliefs has experienced a movement from religious authorities to individuals themselves since they are responsible for the authenticity of their own religious journeys. Consequently, the axis of truth changes from traditional institutions to individual believers. In this section, the first process is further examined on the base of the in-depth interviews and focus group sessions in order to ground some contributions to

\footnotetext{
${ }^{25}$ Giddens, Modernity and Self-Identity, 32.

${ }^{26}$ Hervieu-Léger, “In Search of Certainties”: 60-61.
} 
the research problem theoretically. The next section addresses the latter process for the same purpose.

Regarding the individuation of religious identities, Hervieu-Léger asserts that individuals configure their own little system of beliefs by acquiring available elements from the symbolic market. ${ }^{27}$ In the case of the interviewed South American millennial migrants in Miami, their experience of uprooting and rerooting compels them to reconfigure their Christian identities, that is to say, to reflexively produce their own small narratives, which give an account of the spatial-temporal process of uprooting and rerooting. In such a process, memory rooted in a Christian lineage triggers meaningful beliefs that make sense of their experience. By meaningful beliefs, I mean beliefs that are significant for each individual's self-understanding and, therefore, that are individualized. The question that arises now is how they individualize their beliefs and what the main characteristics of such a complex process are. Dubet's conceptual framework contributes to provide answers.

The questions that express the three different critical perspectives regarding identity, according to Dubet, were part of the questionnaire of both the in-depth interviews and the focus group sessions. In this section, I will develop an analysis of the data compiled in the participants' narratives during both research activities, organizing such analysis on Dubet's identity perspectives, namely self-definition, relationship with others, and stakes of relationships. The three logics that explain both reflexivity and action of the individual in his Sociology of the Experience are transversal to the analysis

${ }^{27}$ Ibid.: 61-62. 
of the three identity perspectives. However, these logics - integration, strategy, and subjectivation - appeared with different strength in each perspective throughout the young migrant's narratives. Hence, the presentation of each perspective is based on further analysis of the logics that appeared as relevant for them. Thus, I aim to give some proper answers about the particular manners in which individuation of believes shapes young South American migrants' religious identities in Miami.

The image of the freelancer can metaphorically synthesize some crucial aspects of the process of individuation of beliefs. As a metaphor, the image might have limits. However, some traits help us describe the individuation process in general in order to describe and understand some specificities based on the young South American migrants' narratives.

It is generally admitted that Sir Walter Scott coined the term "freelance" in his celebrated Ivanhoe. Maurice de Bracy, one of the main Norman villains in the book, says: "I offered Richard the service of my Free Lances, and he refused them-I will lead them to Hull, seize on shipping, and embark for Flanders; thanks to the bustling times, a man of action will always find employment. And thou, Waldemar, wilt thou take lance and shield, and lay down thy policies, and wend along with me, and share the fate which God sends us?"28 Thus, Scott applies the term "free lances" to a mercenary who would fight for whoever lord paid him the most. Two interesting aspects arise. First, the notion of freelance reverts the logic of that time. The lord is not the owner of the lances because the warrior has claimed the right to decide by himself who his lord would be. Second, the

\footnotetext{
${ }^{28}$ Sir Walter Scott, Ivanhoe (public domain), loc. 5664 of 8053, Kindle.
} 
vertical relationship of dominance turns into a momentary trade agreement. Within a market, there is a lord who offers goods and guarantees, and there is a warrior who offers the service of his free lances to the best bidder. The relationship once based on status, stratum, or honor turns to be based on individual benefits reflexively discerned.

Over this literary basis, the word freelancer is applied in the present to a selfemployed person who offers services to clients. This sort of employment is highly preferred by millennials. In the field of business, being a freelancer implies a no longterm commitment to one employer within a fluid market in which the decisions mainly remains with the worker. They decide who they will work for and how long the commitment will last for. The parallels with Maurice de Bracy are clear, but there is a notable difference. Maurice was a mercenary, and the services of his free lance were not considered honorable. In the actual context, being a freelancer is highly accepted in societies and frequently expected by young generations. Our freelance believers have the same traits described above. They claim the right to decide on their system of beliefs and their religious journeys and, therefore, they negotiate their decisions within an increasingly diverse religious market.

\subsection{Resignifying the South American Matrix and Searching for Authenticity}

The first question regarding identity—“Who am I?"- that I used to present Dubet's contribution refers to self-identity. The Christian South American cultural matrix appears as a pivotal and common factor in the millennial migrants' narratives. This characteristic is the given component of the process of configuration of religious identities and is ubiquitous in all the narratives. It takes the form of expectations, roles, or reminiscences. 
In general, it is the least individualized aspect of the process since it is the base on which these believers have made their own journeys, and they can easily recognize this fact. However, there are some aspects of this Christian wrap that are reflexively chosen as a present dimension of their self-identities, especially in terms of the logic of integration.

The first notable aspect is that, beyond their commitment or participation in a religious group, they self-define as Christians. In the cases of those believers who have had more active participation, the inherited matrix together with the individualized decisions form a hard to discriminate continuum. However, those who do not have a religious commitment and self-defines as Christians refer to some aspects that make visible the strength of such a cultural wrap and how they individualize and resignify their own woofs.

Marriage in the church was an example that was repeated twice. When they give their reasons for such a decision, the migrants link the religious ceremony to the certainties of historical roots that are culturally meaningful for them. One of the interviewed men, who has not participated in church activities for many years and selfdefines as "almost agnostic," said:

We got married in the church two years ago. We decided to do that because it was very significant for both of us, even when we are not practitioners. But our parents got married in the church, our grandparents also. It is part of our family traditions. And, honestly, I think that this is the true marriage. The rest are papers that come and go. But that moment was a serious commitment, a true commitment. ${ }^{29}$

\footnotetext{
${ }^{29}$ Interview 06.
} 
For a South American millennial, who self-defines as "almost agnostic" and "nonpractitioner," religious marriage gives him the certainties that legal marriage does not. There is some stability in the religious commitment that is not found anywhere else. The interesting factor is that these certainty and stability lead the believer to choose by himself to get married in the church. He chose it and turned this religious ritual into an appropriate and resignified belief. He individualized its meaning and, consequently, selected it to play an important role in his identity configuration.

Another interesting example was given by a woman who used to have a religious commitment in her hometown, and in the present, she self-defines as Christian and religious, but she does not participate in any activity or attend liturgies or services. At the moment of the focus group session, she was thinking that the following year they (she and her husband) need to choose a school for their little daughter, and she told me that they wanted the child to go to a Catholic school. The reasons for such a decision are remarkable.

We want a Catholic school because they will teach her the same values that we received in Colombia. [...] If I lived there, I would never send her to a religious school because she would receive these values at home and at any school. But here... I think a Catholic school will help us to educate her in her parents' culture. ${ }^{30}$

The main reason for this young migrant's decision was not a religious motivation, in the sense of spirituality or catechesis; rather, the choice was motivated by the link she does between Christianity and the cultural values of her hometown. She amazingly expressed how a decision like this would not be thinkable there because what religion can

\footnotetext{
${ }^{30}$ Focus Group 01.
} 
offer to her daughter's education is part of the cultural environment. The mechanism of the individuation of beliefs in the logic of integration could not have been better described. This freelance believer would consider different strategies in different markets-herelthere - according to her reflected intentions.

Subjectivation is the other Dubet's logic that plays a role regarding self-definition. When they reflexively configure their own system of beliefs, the search for authenticity leads them to put into perspective the previous and the new religious order. As Scott's character, they are true to themselves. Thus, the legitimation of beliefs is ensured by the authenticity of their own spiritual approach. As Hervieu-Léger claims, what gives value to the believer's search, not only in his/her own eyes but also in the eyes of those with whom she/he dialogues is his/her sincerity and her/his personal commitment. Thus, "the endeavor to conform to truths formatted by religious authorities has become completely secondary." 31

I follow the teachings that I like. There are many beautiful things in the Gospels. But there are many other teachings that I don't follow because I don't agree with them and I have to be honest with myself. ${ }^{32}$

Concluding, for a young South American millennial who is rerooting in Miami, Christianity is part of the cultural roots that is in the baggage they bring in Miami. When rerooting, the resignification of meaningful beliefs in the logic of integration refers to cultural values, certainties, stabilities that can only be provided by a cultural matrix. In

\footnotetext{
${ }^{31}$ Danièle Hervieu-Léger, "In Search of Certainties: The Paradoxes of Religiosity in Societies of High Modernity," The Hedgehog Review 8, no. 1-2 (Spring-Summer 2006): 61. Academic OneFile.

${ }^{32}$ Interview 07, interview by Ernesto Fiocchetto, December 2019, transcript.
} 
this context, the individuation of such beliefs implies the reflexive election of religious practices or institutions that, in another context, perhaps they would not choose. The rule for such a selection is authenticity. Therefore, the freelance believers legitimize their own system of beliefs based on the individuals' truths, and not on the institutional orthodoxies.

\subsection{Migrating, Circulating, and Searching for Their Own Benefits}

The second question — "How am I related to others?"- that was used in Dubet's presentation synthesizes the world of relationships in the processes of the configuration of identities. Regarding the logic of integration, the difference between we and they, which might be meaningful in other contexts regarding identities, is not presented as an essential aspect when the young migrants defined their religious identities. They did not express that they differentiated from other religious groups. It is clear that they did, but they did not highlight this element in the narratives about their self-understanding.

In contrast, they circulate from one religious group to the other in search of the one that best fits their needs and expectations and in which they fit the best. Religious individuation is at the base of this pilgrimage. One of the interviewed men narrated how he started to circulate among several churches when he arrived in Miami.

To strengthen myself, I started to go to a church... well, truly, I went to several churches, like three or four different churches. I always tried to search for the same but in different churches... I went to a church in Miami Beach, but that was very liberal. I went to another one that was more Pentecostal and this style doesn't grab my attention. I also went to Guillermo Maldonado's church and so on. I visited many churches. But in one way or another, I took the good things that were in each church. I took those things 
that could guide me, help me with my faith, or help me be stronger. ${ }^{33}$

It is clear how religious circulation is based on personal search according to the believer's needs. Like Bauman's image of the buffet table and the eaters, some millennial migrants also migrate among churches whose boundaries are diffuse. The individuation of beliefs is consequent with the liquidity and mobility of Modernity. Agreeing with HervieuLéger, South American young Christians do not hesitate to move and flow and configure a pilgrim-like form of rerooting in Miami which is willful, individual, and not subjected to fixed boundaries.

Hence, the emphasis in terms of the perspective of relationships is on the logic of strategy. They reflexively address the interactions with other individuals and institutions in order to create the individuals' own benefits.

The pastor's preachings are true because he explains the Bible correctly... I went to many churches, but when I met this pastor, I decided to stay in this community. If the pastor would go for any reason, I would evaluate the preaching of the new one. If I could, I would follow my pastor. But if I like the preaching of the new pastor, I would stay in this community. [...] For me, the form of preaching is more important than the relationships, or other good things in the community. [...] I decide my community for the form of preaching. ${ }^{34}$

In this case, he goes to church because the chosen community met a set of needs and expectations such us a group of reference, and spiritual joy, among other aspects he referred to throughout the interview. However, for this young migrant, the most important was preaching. This is the reason why he chose his community. Good

\footnotetext{
${ }^{33}$ Interview 04.

${ }^{34}$ Interview 07.
} 
preaching is so essential for him that he decided to follow the pastor whom he considered a good preacher according to his expectations. This reflected interaction within a religious group is based on a religious product he chose because it was meaningful —or the most meaningful — for his small system of beliefs. Moreover, this choice is decisive for his continuity or not in the group. If the preacher went to another community, he would seriously consider following him or, after an evaluation of the substitute, starting a new migration until he found a new preacher.

In contrast, he does not accept the preacher speech about tithing as "it should be" but he individually reinterpret the religious practice. Preaching being the pivotal element in his system of beliefs, he decides what to choose from the preaching, and he adapts that pivotal element to his possibilities and convictions.

There is something that I didn't agree from the beginning, but I handled it. I practice tithe, but, from my perspective, when you practices tithe, you don't need to give the ten percent that the church asks for because this rule is based in the Old Testament, and, in the New Testament, Jesus never says that it must be the ten percent. [...] I handled the situation. At the beginning, I gave the ten percent, then I gave less, or perhaps I gave a smaller percentage, but I did other things in the church. [...] I understand that the pastor preaches about it because the church is small and needs the money, but I do want I can. ${ }^{35}$

In conclusion, for a young South American millennial who is rerooting in Miami, the relationships with the religious group are mediatized by his/her subjectivity. The individuation of the religious menu is discerned with instrumental rationality in search of the individuals' own benefits, just as the warrior discerned the Lord whom he would offer the services of his free lances, or just as a freelancer selects his/her clients according to

\footnotetext{
${ }^{35}$ Ibid.
} 
the benefits that she/he would receive. They strategically mix and match and make up their own selection according to their needs, and to that end, they feel free to take from here or there, to circulate and migrate from one group to another in a context of religious fluidity.

\subsection{Avoiding Self-Alienation and Reflexively Considering the Ground of Their}

\section{Actions}

The last question - "What are the stakes in those relationships?"- leads Dubet to analyze how the individual produces a subjective distance with the system in order to explain their social experiences. Maintaining what has been said about religious circulation from one group to another, some of the young migrants find groups of belonging. Thus, a second form of legitimation sometimes completes the legitimation of the system of beliefs based on the individual's non-institutional-regimes of truth.

In the third paradox of religious Modernity, Hervieu-Léger shows how the individuation of beliefs consists of the personalized consumption of symbolic goods that requires the construction of a narrative in order to meet the aim of making meaning of individual experiences. Then, she reasons that there is no possible narrative without the corresponding ability to speak that is inherent to the individual's own identities.

Therefore, the narrative needs otherness outside of which no language is conceivable. ${ }^{36}$ In other words, when the individuals aim to make meaning of religious experiences, they need a religious other that authenticates his/her beliefs by invoking the continuity of a

\footnotetext{
${ }^{36}$ Heriveu-Léger, "In Search of Certainties," 67.
} 
somewhat shared lineage. Thus, believers find community niches where they legitimize the memory involved in their meaningful beliefs.

Throughout their narratives, some interviewees show the significance of these groups of belonging. Moreover, they highlight the emotional links that they have with their communities and how such groups played a significant role in facing loneliness and risks when rerooting in Miami.

They became my family in Miami. I arrived with my family after the crisis (in 2001 in Argentina). I was a teenager and I was alone. I had lost all my friends and relationships. In the parish, I found my friends, my girlfriend, and my boss (he laughs). I am working for a person who goes to the same parish. I love that place... they are important for me. They were important and they are important now. ${ }^{37}$

The two perspectives that are related to the individuation of beliefs, namely religious circulation and community niches, are not to be understood chronologically. One can have the idea that a believer migrates until she/he finds a niche and, then, migration stops. In reality, both aspects coexist in the believers' journeys at least as possibilities. The strategy logic applied to the production of a subjective distance with the system in order to make meaning of the believers' social experiences helps us understand this coexistence. Indeed, the millennial migrants produce a set of strategies of distancing and belonging that they alternatively use regarding the niches they have chosen.

A religious group can help a migrant a lot. It was helpful for me. But then one changes, or things change, and it is not that important anymore. For me, the church was great during my first and second

\footnotetext{
${ }^{37}$ Interview 03.
} 
years in Miami, then, I found other groups, other people. Now I started to go again because I think I need them. It depends... ${ }^{38}$

These freelance believers do not have long-term commitments, and if they had them, such commitments are reflexively addressed once and again under the strategy logic. I do not mean that they cannot remain in a religious group for many years. The emptying of time Giddens refers to does not allow the freelance believers to make longterm decisions in the sense that individuals need to explain their actions continuously through reflexivity. ${ }^{39}$ In circumstances of Late Modernity, individuals routinely keep in touch with the grounds of their actions and decisions and account for them either discursively or through day-to-day behavior. ${ }^{40}$

When I grew up, I became aware. I made many questions: Does he [God] exist or not? What do I believe? I believe this and I don't believe that. And from my teens, I never stopped making questions. I agree with some things and I disagree with others. I make decisions of what I want to do, or not. I'm in the church because I can serve people in need. I have beautiful experiences with homeless people, for example. ${ }^{41}$

This continuous reflexive monitoring of action, as Giddens calls it, makes time a present in which individuals continuously resignify once and again the past, and shapes and reshapes the future. The globalized empty time that rules everyone's lives does not permit standardized long-term commitments; rather, its emptiness entails reiterated moments of individual decisions that can ground momentary commitments.

\footnotetext{
${ }^{38}$ Interview 08.

${ }^{39}$ Anthony Giddens, The Consequences of Modernity, (California: Stanford University Press, 1990), 18.

${ }^{40}$ Ibid., 36, 70.

${ }^{41}$ Focus Group 02.
} 
This emptiness of time refers to an emptiness of religious spaces. For the millennial freelance believers, spaces are not religious by themselves, but such a qualification depends on their reflexivity. To put is simpler, individuals constantly reflect on their religious decisions, and, while they make those decisions, they reinforce (or not) a commitment that is never long-termed by itself, but always remains under the logic of reflexive monitoring of action. Throughout this process, they make meaning of the religious space in which they commit or on which they decide. Therefore, community niches are religious spaces for the individuals as long as they discursively or through dayto-day actions decide that they are part of the shared memory that underpins their little narratives and belief systems.

Lastly, within such coexistence of religious circulation and community niches, the narratives of the young South American migrants present a primacy of the individual regimes of truth over the great institutional governing systems of truth regarding the legitimation of their systems of beliefs. In order to avoid self-alienation, they alienate from the institutional regimes of truth, whether they regularly practice the religion or not.

How do I define tithing? It is personal... I do it according to my consciousness. They say it is the ten percent, but no... I think it is my participation. I feel this way. For me, it isn't a law because nobody can impose it to me. Because if someone imposes it, it would be against your beliefs, because Jesus never said that it was a ten percent. So, for me, it's a matter of participation that you decide upon. ${ }^{42}$

Concluding, for a South American millennial who is rerooting in Miami, the legitimation of their uprooting and rerooting narratives and their systems of beliefs is

\footnotetext{
${ }^{42}$ Interview 05.
} 
based on authenticity which leads them to alienate from the institutional regimes of truth in order to avoid self-alienation. In such a context, religious circulation and belonging to a community niche are reflected continuously in continuous reflexive monitoring of action. Therefore, they routinely consider the grounds of their actions and decisions by making decisions either discursively or through day-to-day behavior.

\section{Freelance Believers II: South American Millennial Migrants and Their Relationships to Religious Institutions in Miami}

Throughout the configuration of their religious identities, South American migrant millennials establish relationships with Christian institutions. The three previous sections have indirectly addressed the issue. In this section, I further examine such relationships on the bases of the analysis of the collected data from the in-depth interviews and focus group sessions. The process of religious deinstitutionalization, as developed by HervieuLéger, is the theoretical frame I discuss in order to ground some contributions to the research problem theoretically.

In section three, the metaphor of the freelance believer indicates that millennial migrant believers claim the right to decide on their system of beliefs within an increasingly diverse religious market. In this section, the other side of the coin of such a metaphor shows the relationship between the believer and the institutions. Just as Maurice de Bracy challenged the prevailing social norms by deciding whom he would serve with his free lances, freelance believers challenge the religious institutional system.

There is a tension that we need to maintain in order to make a thorough analysis of the institutional dimension of the religious identity configuration. On the one hand, 
Maurice de Bracy claimed the right to decide on his free lances by himself and, therefore, he offered his services to the best bidder. On the other hand, Maurice de Bracy needed a lord to make such an offer. Before the independent warriors, some lords offer goods and guarantees. While it is true that de Bracy reverts the institutional logic of belonging of that time, it is also true that the new logic implies a readjustment of the institutions that started to negotiate within a market. Millennial freelancers act similarly within the labor market. They claim for themselves the right to decide who the employer they will chose is. However, they need an employer to offer their services, and consequently, filed of business has readjusted to the millennials' new working logic.

My thesis is that freelance believers challenge religious institutions in both aspects. On the one hand, the individuation of beliefs means that they are alienated from the regimes of truth established by religious institutions and, thus, reflexively create their own little narratives and configure their own little system of beliefs. On the other hand, while doing this, they both put into perspective and strengthen the presence of religious institutions within the process of configuration of their religious identities. Therefore, the concept of deinstitutionalization of religious beliefs needs to be re-thought in order to avoid a misinterpretation of the relationship of freelance believers with religious institutions and to suitably understand such a relationship. The consequences of this thesis for Religious Studies in general and Sociology of Religion, in particular, are challenging. 


\subsection{Putting Institutions into Perspective}

Individualization is a sign of Late Modernity. World risk Society turned individuals into the last boundary of social, political, and economic action; we have assisted to the fall of meta-narratives and the rise of little individual narratives that negotiate goods within a growing symbolic market to legitimize lifestyles; self-identity is a reflexive project of the self. This increasing modern individualization challenges the roles of institutions in modern societies. Religious institutions, in particular, are vulnerable to the impact of Late Modernity.

Modern secularization triggers processes of individuation of belief in which, according to Hervieu-Léger, the traditional remiges of truth that were used to legitimize individuals' belief are challenged by the primacy of authenticity. ${ }^{43}$ Therefore, individuals alienate from institutions when they ground their everyday actions and decisions. Before the weakness of the legitimation power of religious institutions, liberalization of the religious symbol market enables freelance believers to create their own little belief narratives and configure there individualized systems of beliefs and religious identities.

The primacy of authenticity, which rules freelance believers' searches, puts into perspective the orthodoxies upheld by religious institutions and authorities. A brief dialogue in one of the focus group sessions is an eloquent example of this feature. I related to the group two of particular situations based on previous interviews that implied moral conflicts that contradicted the institutional norms. The characters involved did not agree with the official discourse and, however, decided to go on with their religious lives

${ }^{43}$ Hervieu-Léger, "In Search of Certainties": 60-61. 
in the communities. Then, I asked the participants to tell me what they thought about what they heard.

A: It is similar to identifying or self-affiliating with a political party. The political party has a million good and bad things, but when you say, "I'm a Radical," "I'm a Peronist," "I belong to Cambiemos," "I'm a Democrat," or "I'm a Republican," you are saying that you are this or that. So, if you are, you are siding with everything. You can criticize many things, but you're assuming some responsibility, I think. And when you assume responsibilities, there are very good things and very bad things. But I think one identifies with the forest and no with the tree. Clearly, there are bad trees, but you identify with the larger percentage of good things or things you agree with... If you accept everything as it stands, you become a fanatic.

B: Well, no. I think it is like joining a sports club. There are rules and you must follow all the rules. If not, go to another club! Many people do this with religion, and they keep changing and changing because of the rules.

C: Well, but you don't have to follow all the rules. It is like the relationship with a friend, or with yourself... You have good things and bad things. But you decide to belong even when you do not agree with everything. There are bad things, but we...

A: (speaking to B) So, do you respect all the rules in your church? What would have happened if you were part of a conflict? Would you go to another club? (Laughs)

B: To be honest, if I were part of a conflict, I know that I couldn't stay in the club, but I would continue going anyway... (laughs) I don't follow the rules of my religion to the letter, but I won't go to another club because I love mine (laughs).

D: The thing is that I don't have the conflict with my religion. The church may have the conflict with my situation. But I'm ok. I mean, let's suppose that I were gay, and I were happy to be gay. I don't have the conflict, I practice my religion, and I want to practice it and be gay. And it is ok for me. The church has the conflict, not me.

It is true that some things are written and are sacred, but they will change at some point. And I have to be honest with myself. This is also written.

A: Another example: sexual relations before marriage. Do you really believe that people will stop having sex because a priest or a pastor says so? Or that a divorced guy will break up with his new partner? No. And 
they will go to mass if they want to. And they will take communion. And I think it's fine. ${ }^{44}$

The dialogue is fascinating for several reasons: the comparisons, the path from a rigid to more flexible stands in the discourses of $\mathrm{A}$ and $\mathrm{B}$, the role of authenticity and religious authority, the examples they discuss, among other aspects. However, for the purpose of this research, there are three significant elements to highlight.

First, they stress the legitimizing role of authenticity for their religious decisions, even if it contradicts institutional orthodoxies and authorities. They self-identify with the "label," but they negotiate the substance according to their perspectives. The legitimation of the beliefs falls on individual truths and challenges the institutions' role in this respect. The primacy of authenticity is taken to a religious level: "I have to be honest with myself. This is also written." While freelance believers reject the institutional approval of beliefs, the organized structure of the belief systems that is authenticated by religious institutions weakens. $^{45}$

Second, the role of religious authorities is also put into perspective. Against the certainty of the individual convictions, the role of the traditional authorities - priest, pastoral, the sacred, scriptures, norms - lose ground. The regime of truth of these freelance believers sits on themselves and, therefore, sits less and less within the dogmatic frameworks offered by institutional religions. From this perspective, we can go back to the first chapter and better understand the decrease in some of the standard measures of religious commitment that the Pew Research Center proposes, namely

\footnotetext{
${ }^{44}$ Focus Group 02.

${ }^{45}$ Hervieu-Léger, "In Search of Certainties": 60.
} 
importance of religion in everyday life, worship attendance, and frequency of prayer. The three aspects are ruled by an institutional authority that is losing authority in front of millennial believers.

Third, they open the possibility of religious migration. "If not, go to another club. Many people do this with religion, and they keep changing and changing because of the rules." Believers' authenticity can legitimate the search for a place where to believe according to the rules of authenticity. The institutional borders are not strong enough to maintain freelance believers inside the churches. Thus, the other aspect of the Pew Research Center's list is challenged, namely religious affiliation since these migrant believers are pilgrims that move according to their little truths.

Concluding, religious institutions are undermined in three essential aspects: the legitimation role they pretend to have, the different sorts of authorities that rule beliefs, and the institutional borders that shape belonging. From this perspective, religious modernity means the collapse of the religious codes that organized certainties and beliefs. In Late Modernity, religious institutions are liquid and diffuse. However, they keep configuring expected identities. Before those expectations, the freelance believers have multiple individual strategies to negotiate within a market in which religious institutions are losing control, as the lords in the times of Maurice de Bracy did. Religious institutions are losing weight in the narrative identities of the millennial migrants from South America. They search for authenticity in their biographical processes and, therefore, put into perspective assigned identities. They configure their identities as the reflective project of their selves and not as answers that meet institutional expectations. 


\subsection{Strengthening Institutions}

While religious institutions are losing weight in the narrative self of South American millennial migrants, the set of individualized strategies they use throughout the continuous process of configuration of their identities strengthen some institutional dimensions. The analysis of the interviews and focus group sessions that I have presented in this chapter, as well as some data of the baggage they bring to Miami that I tackled in the first chapter, evidence that the continuous spatial-temporal process of uprooting and rerooting resignifies beliefs that are meaningful for migrant's religious memory. Consequently, some dimensions of religious institutions are resignified at different levels.

Firstly, when rerooting in Miami, these South American millennials link their beliefs to a memory rooted in an authoritative tradition that is understood within an institutional belonging.

I go to the church because it links me with my history, with my culture, with my family. ${ }^{46}$

The religious warp in which these migrant freelance believers weave the woofs of their beliefs has an indubitable institutional reference. The importance they give to some religious rituals and liturgies evidences such woofs that make the wrap meaningful for these South American migrants in Miami.

I go to mass for Ash Wednesday and for some other special occasions. Sometimes, I also go when I'm sad, or when something good happens. Perhaps I go five or six times a year, but I go. ${ }^{47}$

\footnotetext{
${ }^{46}$ Interview 02.

${ }^{47}$ Focus Group 02.
} 
Their children's baptism, their own marriage, and any other rite of passage that are meaningful for millennials are celebrated in churches.

Since I arrived in Miami, I have gone to mass a few Sundays. It doesn't mean that I'm not religious anymore. My son was baptized. We do everything with the church. But I have stopped going to mass frequently. ${ }^{48}$

I know that there are things that I will do in the church, for example, I will get married in the church. I mean, the day on which I get married, it has to be in the church because... I don't know why... I mean, it's clear for me that I have to get married in the church. ${ }^{49}$

These rituals strengthen the importance of the institutional presence in Miami for these migrants and, consequently, allow institutions to continue to thrive. It is true that hierarchies criticize and sometimes condemn this kind of decisions and practices. Their expectations imply that believers would project belonging with other parameters of commitment. However, it is also true that this inherited matrix shows the importance of religious institutions in South America. Moreover, the attendance to liturgies and the request of rituals and sacraments actualize such importance now and here. When they reroot in Miami, they strengthen religious institutions because of the actualization of the institutionalized authoritative tradition in which their religious memory is rooted and which triggers meaningful beliefs in a here that is linked to a there. This path from there to here that shapes the migrants' configuration of religious identities strengthens- - though not in the institutionally expected ways - the institutional presence of Christianity in Miami.

\footnotetext{
${ }^{48}$ Ibid.

${ }^{49}$ Interview 08.
} 
Second, the role of "my" community was tackled several times through this chapter. The South American millennial migrants configure emotional bonds that link them to a religious group of reference. Further examples of the emotional importance that such groups have for them can be found in phrases like these: "I feel home there." "They are family." "I won't go to another club because I love mine." When rerooting in a society like the huge Miami, these religious communities play a meaningful role, which may have reminiscences of a religious there and then or may have the newness of a religious here and now. In all the cases, this presence of meaningful emotional bonds strengthens the institutional presence of such groups.

Third, for many reasons addressed above, millennial migrants reflectively search for community niches.

"Churches help a lot because they fill the emptiness and loneliness we feel when we arrive at a new place." 50

The process of individuation of beliefs and its consequent regime of truth that is set in the individuals also need the certainties that meaningful others offer. Hervieu-Léger clearly explains that "there is no possible rendering of spiritual experience as a narrative unless the individual, at some point, meets another individual able to confirm it for him: 'What has meaning for you also has meaning for me." ${ }^{51}$ The search for certainties within a community niche makes such a niche so vital that it is also institutionally strengthened.

In conclusion, while the migrants' religious identity configuration processes undermine some aspects of religious institutions, other institutional dimensions are

\footnotetext{
${ }^{50}$ Focus Group 02.

${ }^{51}$ Hervieu-Léger, "In Search of Certainties": 67.
} 
strengthened. Freelance believers actualize the South American religious matrix especially by attending to liturgies and requesting rituals and sacraments. They emotionally bond with groups of reference that are meaningful in the processes or uprooting and rerooting. They find community niches that confirm the certainties of their little identity narratives. The reflexive identity of the millennial migrants from the southern continent refers to reflected commitments and subjective meaningful identification with communities that lead to strengthening institutional presences of the groups beyond the hierarchical expectations and the individual strategies.

\subsection{Re-Thinking Religious Institutions}

Throughout the process of configuration of South American millennial migrants' religious identities, the individuation of beliefs plays a versatile role regarding institutions. On the one hand, they put into perspective some aspects that traditionally have defined the essence of religious institutions, their authority, and social presence. They challenge the religious institutions' expectations and give rise to new forms of religious beliefs that are multifaceted, hybrid, and alienated from institutionalized tradition. On the other hand, the little narratives that migrants produce strengthen the presence of religious institutions since some of those multifaceted, hybrid, and institutionally alienated beliefs link their religious identity configuration to various institutional dimensions.

Borrowing from feminist perspectives, in order to make a thorough analysis of the relationships that South American millennial migrants have to Christian institutions throughout the process of configuration of religious identities, I propose to replace the 
logic of either/or by the logic of neither/nor. ${ }^{52}$ The term deinstitutionalization might refer to the first logic that I think we have to avoid in social sciences of religion. Either a believer is institutionalized because she/he complies with a set of features that allows us to say so, or he/she is deinstitutionalized because those features are not present within their narratives and lifestyles. I propose that there is no such logic. Migrant freelance believers in Miami neither are institutionalized nor are deinstitutionalized according to such a set of preselected features. Instead, they have their own and new manners to relate to institutions.

From the interviews and focus group sessions, we conclude that while these South American migrant freelance believers legitimize their meaningful beliefs out of the frame of institutional orthodoxies and regimes of truth, they emotionally bond with religious groups of reference. While they put into perspective the regulatory role of religious authorities, they participate and request from such authorities diverse liturgies, rituals, and sacraments. While they challenge religious boundaries and freely migrate from community to community, they establish commitment and belonging, more or less durable, with community niches that offer certainty to their beliefs. In the process of uprooting and rerooting, these migrant Christians negotiate strategies with institutions; make meaning of places, communities, and authorities; take distance of orthodoxies while they search for authenticity; select rituals, liturgies, practices from a vast religious symbolic market; and reflexively keep narratives that make sense of their nows and thens, heres and theres.

\footnotetext{
${ }^{52}$ Jennifer Hyndman, "Beyond Either/Or: A Feminist Analysis of September 11 $1^{\text {th }}$ " ACME: An
} International E-Journal for Critical Geographies, 2, no. 1 (2003): 10. 
Account taken of all the above, should we speak of a process of religious deinstitutionalization? Some further considerations can help answer the question.

Firstly, it must be admitted that most times in the Social Sciences of Religion and in Religious Studies, when we refer to religious institutions, we are speaking about the official hierarchical discourses or the official expectations of such institutions. We are traditionally speaking of traditional institutions. In this regard, the term deinstitutionalization might be correct. As this work evidences, many traditional aspects of religious institutions are challenged and do not play a role in the processes of religious identity configuration of South American millennials in the migratory context of Miami.

However, it is urgent for the Social Sciences and Religious Studies in general, and the Sociology of Religion in particular, to rethink such a concept. In other fields, the notion of institutions has evolved, but in the Social Sciences of Religion, we continue to think religion in a traditional way: a temple, with a number of people taking part in liturgies, doctrines that rule their lives, authorities who made meaningful decisions for followers, followers who agree with such decisions, adscriptions that means a whole acceptance of the institutional expectations.

What would happen if we apply such a notion of institutions to other present experiences? For example, it would be difficult to admit that some NGOs, like Doctors Without Borders or Greenpeace, are not also within a deinstitutionalization process. In fact, how many members of such organizations know the name of the president, or have frequent contact with the rest of the members? How many are committed with concrete actions beyond the monthly financial contribution that is debited from their bank accounts? Where are the physical headquarters or offices, and who usually goes there? 
The list of questions can continue, but these can are enough to show that the majority of the members of such institutions are individualized, do not show up to offices, do not have an active commitment, do not know their authorities, and probably do not pay attention a lot in the organization's rules or dispositions. However, we are not in any doubt about the fact that such NGOs are institutions. Of course, they are institutions but different from institutions in the past.

Therefore, I consider that the Social Sciences of Religion need to rethink the notion of a religious institution and make it suitable to our times because we continue to analyze them with outdated paradigms. We also have to consider that all modern institutions experience the process of deinstitutionalization. The fall of meta-narratives affects not only religion; rather, it is pervasive and crosscutting to Late Modernity, and it consequently affects to democracy, state, nation, political parties, law, heteronormative family, art, education and schooling, and geographical boundaries, among many others social dimensions. Considering that all these social dimensions are deinstitutionalized is abusive. Considering that only religion is deinstitutionalized and the other dimensions are reshaped by modernity is an ideological bias.

Second, keeping a traditional notion of institutionalization precludes some institutionalized experiences that are meaningful for the configuration of religious identities of the participants in this study. For example, when introducing the paradox of the community niches, Hervie-Léger writes: "The most striking paradox of this situation is this: the more beliefs circulate, the less they determine tangible affiliations and the more they further a desire for community liable to evolve into intensive forms of 
religious socialization." ${ }^{, 53}$ I wonder why affiliation is related to the great Christian tradition and not to the community niches. Is not the affiliation to such niches tangible? In a few words, niches are institutions, or at least, have many institutionalized dimensions: they have rules, authority, some members, and belonging criteria. If we maintain the logic of either/or regarding deinstitutionalization, we risk invisibilizing new institutionalized religious experiences that are pivotal for the configuration or religious identities of South American millennial migrants in Miami.

Third, it is imperative to avoid the bias that defines institutions form the expectations of authorities or hierarchies. Institutions are more than hierarchical and legal apparatus. In this regard, two aspects are highlighted. On the one hand, religious institutions are comprised mainly of a massive number of individuals who are not part of the hierarchies, like the millennial migrants from South America who took part in this study. These believers shape and reshape their churches, communities, niches, or religious groups of references. In this regard, a more democratic notion of religious institution is necessary.

On the other hand, we cannot think of religious institutions as a solid structure with no internal cracking, or no dissidence. Indeed, hierarchies are not a solid block of thoughts, beliefs, and traditions, and we can assert that, for instance, there are many Catholicisms within Catholicism. The history of Christianity in South America is an excellent example of the diversity that exists inside religious hierarchies. The expectations of the hierarchies that sociologists take into consideration when elaborating

\footnotetext{
${ }^{53}$ Hervieu-Léger, "In Search of Certainties”: 66.
} 
religious indicators are generally the ones of the conservative or official hierarchies. Such a perspective does not take account of the complexity of religious institutional authorities.

Fourth, regarding this last aspect of religious hierarchies, some hierarchical strategies show that they are adapting to the new scenario that believers construct while they configure their identities. An in-depth study of this aspect is beyond the scope of this research, but Hervieu-Léger, for example, accounts for the fact that "religious authorities themselves are contributing to this movement, by giving greater weight to the quality of personal spiritual experiences than to the strict orthodoxy of statements of belief." 54 Following this logic, one. One of the participants narrated in the focus group session:

I have a friend who joined a divorced woman. He went to confession and the priest told him that he could take communion if he felt that he is not in grave $\sin .{ }^{55}$

Then, we can argue that hierarchies are also negotiating within the religious market, like the lords who readjusted their logic to the logic of Maurice de Bracy and his free lances. Indeed, this would be a topic that calls for further analysis.

The perspective of neither/nor helps us better understand a complex field. If we assume that, in the process of configuring their religious identities, these South American millennial migrants in Miami are not relating to religious institutions in expected traditional manners, we are able to analyze their belonging and commitment from different perspectives. Therefore, we can assert that they neither are institutionalized nor

\footnotetext{
${ }^{54}$ Ibid.: 61.

${ }^{55}$ Focus Group 02.
} 
are deinstitutionalized according to generally accepted set of features; rather, they are shaping their own and new manners of belonging.

As a consequence of this assumption, we must rethink the interpretations of the data collected in polls. As developed in chapter one, the Pew Research Center takes four standard measures of religious commitment, namely affiliation, importance of religion, worship attendance, and frequency of prayer. Many conclusions about institutional growth or setback are based on these measures, which are useful but limited when it comes to interpretation. For example, in a 2014 report titled "The Shifting Religious Identity of Latinos in the United States," the Center expresses: "The share of Hispanics who are Catholic likely has been in decline for at least the last few decades. But as recently as 2010, Pew Research polling found that fully two-thirds of Hispanics (67\%) were Catholic. That means the Catholic share has dropped by 12 percentage points in just the last four years, using Pew Research's standard survey question about religious affiliation. ${ }^{" 56}$ From the theoretical perspective proposed in this study, it is necessary to assert that the link between religious affiliation to Catholicism and being a Catholic is arbitrary. In fact, it is a clear example of the application of the either/or logic to belonging to a religious institution. Either one self-affiliates to a religious traditoin $o r$ she/he is not Catholic. The interviews and focus groups sessions that ground this study show that the configuration of religious identities of these South American millennial migrants in Miami does not work under such simplistic logic.

\footnotetext{
56 Pew Research Center, "The Shifting Religious Identity of Latinos in the United States: Nearly One-inFour Latinos Are Former Catholics," May 7, 2014: 5-6. http://www.pewresearch.org/wpcontent/uploads/sites/7/2014/05/Latinos-Religion-07-22-full-report.pdf
} 
Therefore, we can better understand the difficult-to-explain data at the end of the first chapter. Within the complex religious landscape of Miami and the U.S., there are individuals in Miami who believe in God and are not affiliated with a religious tradition; there are individuals who do not believe in God but are affiliated with a religious tradition; there are individuals in Miami who perform religious practices that imply religious institutions, but they are not affiliated with a religious tradition; there are individuals who self-define as Christians and seldom or never pray. These features and many others related to the complex issues of religions and, particularly, Christianity in Western globalized societies find a better understanding if one considers the theoretical contributions in this work.

In fact, this study argues that the migrant's religious identity configuration consists of a continuous spatial-temporal process of uprooting and rerooting, in which a memory rooted in an authoritative religious tradition triggers beliefs that are meaningful for the migrant's self-understanding. While configuring their identities, South American millennials in Miami shape their own and new manners of belonging and relating to religious institutions within a process of individuation of belief that is typical of Late Modernity. Beyond the limits of this study, this contribution can potentially shed light on others experiences that are similar in context. To be sure, in an era of globalized realities, many people are configuring their religious identities in the complex times and spaces that continue to be rooted in Late Modernity. 


\section{CONCLUSIONS: Uprooting and Rerooting Religious Identities}

I started this study with the aim of grounding middle-range theory that makes sense of the social configuration of religious identities of South American millennial migrants who self-identify as Christians in Miami-Dade County in order to contribute to a better understanding of this process. To achieve such a goal, three steps were necessary.

First, in approaching the millennials' South America, the main characteristics of the baggage with which these migrants arrived in Miami were disclosed. They moved from a continent shaped by Neoliberalist and Post-Neoliberalist socio-politico-economic processes that have favored social impoverishment and increasing social vulnerability. Moreover, such processes eventually ended in several economic and politic crises that some countries faced in particular moments of their history. Both aspects are at the base of the international migration of millennials from the southern continent to Miami. It is worth mentioning that the study subjects of this research are themselves one of the major contributions of this work given the absence of studies on South American migrants and religion in Miami.

The baggage of these young migrants also included cultural and, therefore, religious aspects. They come from a continent whose Christian Catholic matrix is a habitus that equally shapes the religious experience of South Americans. Over this wrap, millennials witnessed the emergence of Christian forms with fluid boundaries and several new religious experiences that have been reshaping the South American religious landscape during the last decades. The processes of secularization manifest in the increasing individualization of religious experiences; the emergence of new modes of 
belief with different levels of independence of the religious institutions; the consequent religious circulation; and the resulting diverse, complex, and hybrid individualized systems of beliefs.

The migrants and their baggage arrived in Miami, the immigrant city of the United States that hosts a quarter million of South Americans. This multicultural metropolis is a young city where millennials are the most numerous age group and around 50 percent of the labor force of the area. Miami also boasts a highly diversified religious landscape, in which around 80 percent of its population self-affiliate with a religious tradition, Christianity being the one that has more followers.

Second, a selected number of scholars help me ground the process of identity configuration within Late Modernity. Ulrich Beck asserts that in the world risk societies the configuration of identities is absolutely individualized since individuals can only seek refuge by themselves. They are the last boundary of responsibility for the sake of one's own and others' survival and, therefore, the configuration of one's own identity is an individualized task. Zygmunt Bauman explains how in liquid societies individuals are constrained to fetishize their subjectivities because nobody is able to become a subject if one has not previously become a product within a market of produced identities. Giddens claims that the context of Late Modernity implies the increase of social reflexivity. The self becoming a reflexive project, individuals continuously construct personal narratives in order to understand themselves. Hence, self-identity is the self as reflexively understood by the person in terms of his/her biography.

From nominalist and existentialist perspectives, Francoise Dubet and Claude Dubar consider that identities are not something that remains identical, but they are the 
result of multiple contingent identifications. The approaches of these two French sociologists allowed me to ground the process of religious identity configuration by deepening their theoretical perspectives and, particularly, by taking advantage of the operationalization of concepts they offer for analysis purposes.

Hervieu-Léger's contribution to the Sociology of Religion is crucial to this work. She understands secularization as the set of processes of readjustment of the beliefs in the context of modern instability and uncertainty. This perspective regarding the notion of secularization allows her to analyze religion by elaborating on two core concepts, namely, the process of individuation of beliefs and religious deinstitutionalization. As a result, she considers that religious experiences are multifaceted, syncretistic, hybrid, and alienated from institutions.

The French sociologist's definition of religion is another concept that is pivotal for this thesis. She argues that religion is an ideological, practical, and symbolic system through which consciousness of belonging to a particular chain of belief is constituted, maintained, developed, and controlled. Therefore, she suggests that religion in the modern world is to be comprehended as a way of believing that is rooted in an authoritative tradition, that is, a chain of belief. It is the act of believing within a religious tradition that legitimates believers' practices and decisions.

After these two steps, I focused on the two research questions that guided my investigation in order to properly ground answers based on continuous feedback between the contextual and theoretical grounds and the living grounds of the sixteen men and women who participated in this project. Deepening in the words and meanings that these South American millennial migrants who self-identify as Christians shared with me in the 
interviews and focus group sessions excited my sociological imagination in order to offer several answers, which are the main contribution of this work.

One of the contributions is the understanding of the process of configuration of religious identity from the perspective of migrants. I argue that the migrant's religious identity configuration consists of a continuous spatial-temporal process of uprooting and rerooting, in which a memory rooted in an authoritative religious tradition triggers beliefs that are meaningful for the migrant's self-understanding. Such a notion gives account of the relational, non-essentialist, and processual understanding of identities that underpins my work. Moreover, it embodies identities in spatial-time categories that make sense of the migrants' nows, and thens, heres and theres. In addition, such an approach assumes a conception of religion in Hervieu-Léger's perspective, that is to say, religion as memory legitimized by an authoritative tradition that is a source of meaningful beliefs for the migrants. The conclusions of this work, which answer the two questions that guided this study, are rooted and shaped by this notion of religious identity configuration in migratory contexts.

The first research question reads: "How do South American millennial migrants who self-identify as Christians configure their religious identities in Miami-Dade County?" The ubiquitous process of individuation of beliefs that Hervieu-Léger develops and is a characteristic feature of Late Modernity pervades all the answers, which can be synthesized in the following conclusions.

These millennial believers resignify the memory rooted in the authoritative tradition of their countries in South American as a cultural matrix and integrate it into the self's story about themselves. The young migrants claimed the inherited South American 
Christian identity as a socialization element. At the same time, such a cultural matrix that offered safety and certainty there and then is reenacted here and now in small religious communities in Miami. Therefore, Miami is resignified across a process of appropriation of the place where they reroot, in which the huge and risky city is also the city of "my" small group of reference.

In trying to reroot, the migrant millennials negotiate their socialized and reflexive selves. They migrate within a complex and diverse system of religious institutions and use different strategies to interact with them. Some of them choose their group of belonging by giving a subjective meaning to the community with which they identify. The level of commitment to the groups depends on the search of their individual benefits. Whether they configure a status identity for others or a reflexive identity for themselves, the spatial dimension of the configuration of their religious identities plays a role in rerooting their migrant existences in Miami.

South American millennial migrants in Miami do not self-identify as Christians by chance, or just because they inherited this tradition. There is a religious memory rooted in an authoritative tradition that gives meaning to a set of reflexively selected beliefs and helps these South American millennials uproot and reroot in a continuous process of identity configuration through significant spaces and times. While they configure their identities as a reflexive project, they produce narratives that find continuity in a memory rooted in a believing lineage and allow the millennial migrants to self-understand as Christians by a set of meaningful beliefs from there and here, now and then. 
The metaphor of the freelance believer expresses more particularly some features of the individuation of beliefs in the experience of South American millennial migrants in Miami. They claim the right to decide on their system of beliefs and their religious journeys while they negotiate their decisions within an increasingly diverse religious market. For these freelance believers who are rerooting in Miami, the resignification of meaningful beliefs in the logic of integration refers to cultural values, certainties, stabilities that can only be provided by a Christian-Catholic cultural matrix. In this context, the individuation of such beliefs implies the reflexive election of religious practices or institutions that, in another context, perhaps they would not choose. The rule for such a selection is authenticity. Therefore, the freelance believers legitimize their own system of beliefs based on the individuals' truths, and not on the institutional orthodoxies.

Moreover, the individuals' relationships with the religious groups are mediatized by their subjectivities. The individuation of the religious menu is discerned with instrumental rationality in search of the individuals' own benefits. They strategically mix and match, and make up their own selection according to their needs, and to that end, they feel free to take from here or there, and to circulate and migrate from one group to another in a context of religious fluidity.

Lastly, this part of the study concludes that the legitimation of their uprooting and rerooting narratives and their systems of beliefs is based on authenticity, which leads them to alienate from the institutional regimes of truth in order to avoid self-alienation. In such a context, religious circulation and belonging to a community niche are reflected continuously in reflexive monitoring of action. Therefore, the South American 
millennials who are rerooting in Miami routinely consider the grounds of their actions and decisions either discursively or through day-to-day behavior.

The second research question that guides this work reads: "How can we understand the relationships that South American millennial migrants who self-identify as Christians have to religious institutions in Miami-Dade County throughout the process of configuration of religious identities?" The process of religious deinstitutionalization, as developed by Hervieu-Léger, is the theoretical frame I discussed in order to ground some contributions to the research question. Based on the previous conclusions, the answers challenge the notion of religious deinstitutionalization and put into perspective some taken for granted concepts and procedures in the Sociology of Religion, and in the Social Sciences of Religion and Religious Studies. The following paragraphs synthesize my conclusions, the challenges for such fields of study, and some emerging research loci for future inquiry.

My thesis is that freelance believers challenge religious institutions in two aspects. On the one hand, the individuation of beliefs means that they alienate from the regimes of truth established by religious institutions and, thus, reflexively create their own little narratives and configure their own little system of beliefs. On the other hand, while doing this, they both put into perspective and strengthen the presence of religious institutions within the process of configuration of their religious identities. Therefore, the concept of deinstitutionalization of religious beliefs needs to be re-thought in order to avoid a misinterpretation of the relationship of freelance Christian believers with religious institutions and to suitably understand such a relationship. 
Christian religious institutions in Miami are undermined in three essential aspects: the legitimation role they pretend to have, the different sorts of authorities that rule beliefs, and the institutional borders that shape belonging. In Late Modernity, religious institutions are liquid and diffuse. Nevertheless, they keep configuring expected identities. Before those expectations, the freelance believers have multiple individual strategies to negotiate within a market in which religious institutions are losing control and weight in the narrative identities of the millennial migrants from South America. They search for authenticity in their biographical processes and, therefore, put into perspective assigned identities. They configure their identities as the reflective project of their selves and not as answers that meet institutional expectations.

However, while the migrants' religious identity configuration processes undermine such aspects, other institutional dimensions are strengthened. Freelance believers actualize the South American Christian-Catholic matrix especially by attending to liturgies and requesting rituals and sacraments. They emotionally bond with groups of reference that are meaningful in the processes of uprooting and rerooting. They find community niches that confirm the certainties of their little identity narratives. Their reflexive identity refers to reflected commitments and subjective meaningful identification with communities that lead to strengthening institutional presences of Christian groups.

Throughout the process of their religious identity configuration, the individuation of beliefs plays a versatile role regarding institutions. Borrowing from feminist perspectives, I propose to replace the logic of either/or by the logic of neither/nor. The term deinstitutionalization might refer to the first logic since it implies that either a 
believer is institutionalized because she/he complies with a set of features that allows us to say so, or he/she is deinstitutionalized because those features are not present within their narratives and lifestyles. My thesis is that there is no such logic. Migrant freelance Christian believers in Miami neither are institutionalized nor are deinstitutionalized according to such a set of preselected features. Instead, they have their own and new manners of relating to institutions.

Consequently, it is urgent for the Social Sciences of Religion and Religious Studies to rethink the concept of religious institution and make it suitable for our times because we continue to analyze them with outdated paradigms. Keeping a traditional notion of institutionalization obfuscates some institutionalized experiences that are meaningful for the configuration of religious identities of the participants in this study. Therefore, if we maintain the logic of either/or regarding deinstitutionalization, we risk invisibilizing new institutionalized religious experiences that are pivotal for the identity configuration of Christian South American millennial migrants in Miami.

I also consider that Social Sciences of Religion need to avoid the bias that defines institutions from the expectations of authorities and hierarchies because religious institutions are comprised mainly of a massive number of individuals who are not part of the hierarchies and shape their churches, communities, niches, and religious groups of reference. Moreover, hierarchies are not a solid bock of thoughts, beliefs, and traditions and they have their own strategies to readjust to the new scenarios that believers construct while they configure their identities.

South American millennial migrants who self-identify as Christians in Miami, thus, are not relating to religious institutions in expected traditional manners. They 
neither are institutionalized nor are deinstitutionalized according to the generally accepted set of features that are evaluated in both quantitative and qualitative research. Rather, they are shaping their own and new manners of belonging. Therefore, we need to analyze their belonging and commitment from a different perspective than the logic of either/or. The newness of the relationship between believers and institutions is a challenging field that needs further studies. I hope that the insights of this work, based on a very specific population, can stimulate new views, perspectives, and research beyond the logic of either/or that dominates the quantitative Sociology in particular, and Social Sciences of Religion and Religious Studies in general. Going forward in my future research, I would like to investigate some aspects which went unanalyzed in this investigation and some of the multifaceted dimensions on which it can potentially shed light. 


\section{REFERENCES}

Adam, Barbara, Ulrich Beck, and Joost Van Loon, eds. The Risk Society and Beyond:

Critical Issues for Social Theory. London: Sage Publications, 2000.

Bauman, Whitney, Richard Bohannon, and Kevin J. O'Brien, eds. Grounding Religion: A Field Guide to the Study of Religion and Ecology. 2nd ed. London and New York: Routledge, 2017.

Bauman, Zygmunt. Consuming Life. Massachusetts: Polity Press, 2007.

. "From Pilgrim to Tourist - or a Short History of Identity." In Questions of Cultural Identity, edited by Stuart Hall and Paul du Gay, 18-36. Oxford, Thousand Oaks, New Delhi: Sage Publications, 2011.

. Liquid Modernity. Cambridge: Polity Press; Massachusetts: Blackwell, 2000.

. "Migration and identities in the globalized world." Philosophy and Social Criticism 37, no. 4 (2011): 425-435. DOI: 10.1177/0191453710396809

. Modernity and Ambivalence. New York: Cornell University Press, 1991.

. The Arte of Life. Massachusetts: Polity Press, 2008.

Beck, Ulrich. "Global Risk Society.” In The Wiley-Blackwell Encyclopedia of Globalization, edited by George Ritzer. Blackwell Publishing Ltd, 2012. DOI:10.1002/9780470670590.wbeog242

. "Individualism." In The Wiley-Blackwell Encyclopedia of Globalization, edited by George Ritzer. Blackwell Publishing Ltd, 2012.

DOI:10.1002/9780470670590.wbeog292

Beck, Ulrich. "Reflexivity." In The Wiley-Blackwell Encyclopedia of Globalization, edited by George Ritzer. Blackwell Publishing Ltd, 2012.

DOI:10.1002/9780470670590.wbeog486

. "Religion, world." In The Wiley-Blackwell Encyclopedia of Globalization, edited by George Ritzer. Blackwell Publishing Ltd, 2012.

DOI:10.1002/9780470670590.wbeog492

. Risk Society: towards a new modernity. California: Sage Publications, 1992.

. "Second Modernity." In The Wiley-Blackwell Encyclopedia of Globalization, edited by George Ritzer. Blackwell Publishing Ltd, 2012.

DOI:10.1002/9780470670590.wbeog583 
. "World at Risk: The New Task of Critical Theory." Development and Society 37, no. 1 (2008): 1-21. http://www.jstor.org.ezproxy.fiu.edu/stable/deveandsoci.37.1.1.

Beck, Ulrich, and Elisabeth Beck-Gernsheim. Individualization: Institutionalized Individualism and Its Social and Political Consequences. London: Sage Publications, 2002.

Bidegain, Ana Maria. "El Año 1968: desarrollos en sociedad, política e iglesia desde la perspectiva de la historia de la iglesia." Paper presented at the Pontifical Catholic University of Peru, Lima, September 6, 2018.

. "El Contexto General que nos ayude a entender posturas y decisiones." In Obispos de la Patria Grande: Pastores, Profetas y Mártires, edited by Ana Maria Bidegain, 17-36. Bogotá: Consejo Episcopal Latinoamericano: 2018.

, ed. Presencia Colombiana En Estados Unidos: Caracterización de La Población Inmigrante. Bogota: Imprenta Nacional de Colombia, 2008.

Brubaker, Rogers and Frederick Cooper. "Beyond 'Identity." Theory and Society 29, no.1 (2000): 1-47.

CEPAL. "Panorama de la migración internacional en América del Sur." Executive Report of the Reunión regional latinoamericana y caribeña de expertas y expertos en migración internacional preparatoria del Pacto mundial para una migración segura, ordenada y regular. Santiago de Chile, August, 2017.

https://refugeesmigrants.un.org/sites/default/files/eclac_america_del_sur_resumen_ ejecutivo.pdf

. Panorama social de América Latina. Santiago de Chile: Naciones Unidas, 1995. https://www.cepal.org/es/publicaciones/1242-panorama-social-america-latina-1995

. Una década de desarrollo en América Latina, 1990-1999. Santiago de Chile:

Naciones Unidas, 2004.

https://repositorio.cepal.org/bitstream/handle/11362/2382/S2004000_es.pdf;sequen $\mathrm{ce}=1$

Conde, Yvonne. Operation Pedro Pan: The Untold Exodus of 14,048 Cuban Children. New York: Routledge, 1999.

Corbin, Juliet and Anselm Strauss. Basics of Qualitative Research: Techniques and Procedures for Developing Grounded Theory. Los Angeles: Sage Publications Inc, 2008. 
Davie, Grace. "From Obligation to Consumption: A Framework for Reflection in Northern Europe." Political Theology 6, no.3 (2005): 281-301. DOI:

10.1558/poth.6.3.281.66128

. Religion in Britain since 1945: believing without belonging. Oxford: Blackwell Publishers; Massachusetts, Basil Blackwell Inc., 1994.

. Religion in Modern Europe: A Memory Mutates. Oxford and New York: Oxford University Press, 2000. Kindle Edition.

Dawson, Matt. "Bauman, Beck, Giddens and our understanding of politics in late modernity." Journal of Power 3, no. 2 (2010): 189-207. DOI:

10.1080/17540291.2010.493698

De la Torre, Miguel. La Lucha for Cuba: Religion and Politics on the Streets of Miami. Berkeley: University of California Press, 2003.

Deal, William E. And Timithy K. Beal. Theory for Religious Studies. London and New York: Routledge, 2004.

Denzin, Norman and Yvonna Linconln, eds. The Sage Handbook of Qualitative Research. Los Angeles, London, New Delhi, Singapore, Washingon, and Melbourne: Sage Publications, Inc. 2018.

Dey, Ian. Grounding Grounded Theory: Ghidelines for Qualitative Inquiry. San Diego and London: Academic Press, 1999.

Dimock, Michael. "Defining generations: Where Millennials end and Generation Z begins." PEW Research Center. Accessed January 28, 2019. http://www.pewresearch.org/fact-tank/2019/01/17/where-millennials-end-andgeneration-z-begins/

Dubar, Claude. La crisis de las identidades: La interpretación de una mutación. Barcelona: Ediciones Ballaterra, 2002.

Dubet, Francoise. "De la sociología de la identidad a la socilogía del sujeto." Estudios Sociológicos 7, no. 21 (1989): 519-45. https://dialnet-uniriojaes.ezproxy.fiu.edu/servlet/articulo?codigo $=447018$ . La experiencia sociológica. Barcelona: Editorial Gedisa, 2011. . Sociología de la experiencia. Madrid: Editorial Complutense, 2010.

Durkheim, Émile. Division of Labor in Society. Illinois: The Free Press of Glencoe, 1960. 
Engels, Friedrich, and Karl Marx. The Communist Manifesto. The Project Gutenberg, 2005. Kindle Edition.

Fiocchetto, Ernesto. "Forty-Five Minutes of Intense Connectivity: Religious Identities in the Time of Information and Communications Technologies." In World Christianity, Urbanization, and Identity, Series World Christianity and Public Religion, vol. 3, edited by Moses Biney, Kenneth Ngwa, and Raimundo Barreto, (Fortress Press: Expected publication Fall 2019)

Fiocchetto, Ernesto, and Azucena Reyes Suárez. "Aportes sobre el concepto de 'identidad' en la Sociología de la Religión." MILLCAYAC - Revista Digital de Ciencias Sociales 3, no. 5 (2016), 133-52. http://revistas.uncu.edu.ar/ojs/index.php/millca-digital/article/view/765/473

French, John. "Understanding the Politics of Latin America's Plural Lefts (Chavez/Lula): Social Democracy, Populism and Convergence on the Path to a Post-Neoliberal world." Third World Quarterly 30, no. 2 (2009): 349-70. DOI : $10.1080 / 01436590802681090$

Frigerio, Alejandro. "Repensando el monopolio religioso del catolicismo en la Argentina." In Ciencias sociales y religión en América Latina: perspectivas en debate, edited by Maria Julia Carozzi and Cesar Ceriani Cernadas, 87-116. Buenos Aires: Biblos, 2007.

Foster, Jed. "The Young and the Religious: Acceptance of Evolution among Millennials at an Evangelical Christian University." Papers \& Publications: Interdisciplinary Journal of Undergraduate Research 6, acticle 17 (2017): 87-101. https://digitalcommons.northgeorgia.edu/papersandpubs/vol6/iss1/17

Gamarra, Eduardo. "Market-Oriented Reforms and Democratization in Latin America: Challenges of the 1990s." In Latin American Political Economy in the Age of Neoliberal Reform: Theoretical and comparative Perspectives for the 1990s, edited by William Smith, Carlos Acuña, and Eduardo Gamarra, 1-15. New Brunswick and London: Transaction Publishers, 1994.

Giddens, Anthony. Modernity and Self-Identity: Self and Society in the Late Modern Age. California: Stanford University Press, 1991. . The Consequences of Modernity. California: Stanford University Press, 1990.

Gutiérrez-Rubí, Antoni. Millennials en Latinoamérica: Una perspectiva desde Ecuador. Madrid: Fundación Telefónica, 2016. 
Haddad, Yvonne Yazbeck, Jane Smith, and John Esposito. Religion and Immigration: Christian, Jewish, and Muslim Experiences in the United States. Walnut Creek, Lanham, New York, and Oxford: Altamira Press, 2003.

Handler, Richard. "On Dialogue and Destructive Analysis. Problems in Narrating nationalism and Ethnicity." Journal of Anthropological Research 41 (1985): 17182.

. "Is 'Identity' a Useful Cross-cultural concept?" In Commemorations: The Politics of National Identity, edited by John Gillis, 27-40. Princeton: Princeton University Press, 1994.

Harvey, David. The Condition of Postmodernity: An Enquiry into the Origins of Cultural Change. Massachusetts: Blackwell Publishers, 1990.

Hervieu-Léger, Danièle. El Peregrino y el Convertido: La religión en movimiento. Mexico D.F.: Ediciones del Helénico, 2004.

. "In Search of Certainties: The Paradoxes of Religiosity in Societies of High Modernity." The Hedgehog Review 8, no. 1-2 (Spring-Summer 2006): 56-68. Academic OneFile.

. "Present-Day Emotional Renewals: The End of Secularization or the End of Religion?" In A Future for Religion?: New Paradigms for Social Analysis, edited by William H. Swaton, Jr., 129-48. Newbury Park, London, and New Dehli: Sage Publications, 1993.

. "Producciones de la Modernidad Religiosa." In Modernidad, Religión y Memoria, edited by Fortunato Mallimaci, 15-40. Buenos Aires: Ediciones Colihue, 2008.

. "Religion and Modernity in the French Context: For a New Approach to Secularization." Sociological Analysis 51 (1990): 15-25. DOI: 10.2307/3711671.

. Religion as a Chain of Memory. New Brunswick, N.J.: Rutgers University Press, 2000.

. "The role of religion in establishing social cohesion." Eurozine, 17 (August

2006). http://www.eurozine.com/articles/2006-08-17-hervieuleger-en.html

. "The transmission and formation of socio-religious identities in modernity: An analytical essay on the trajectories of identification." International Sociology 13, no. 2 (1998): 213-28. DOI: 10.1177/026858098013002005.

Hyndman, Jennifer. "Beyond Either/Or: A Feminist Analysis of September 11th." ACME: An International E-Journal for Critical Geographies, 2, no. 1 (2003): 1-13. 
IOM. "South American Migration Report N. I - 2017.” June, 2017. http://robuenosaires.iom.int/sites/default/files/Documentos\%20PDFs/Report_Migra tion_Trends_South_America_N1_EN.pdf

Kunin, Seth D. Religion: The Modern Theories. Baltimore and London: The Johns Hopkins University Press, 2003.

Levitt, Peggy. Good needs no Passport: Immigrants and the Changing American Religious Landscape. New York, London: The New Press, 2007.

. The Transnational Villagers. Berkeley, Los Angeles, and London: University of California Press, 2001.

Lincoln, Yvonna, Susan Lynham, and Egon Guba. "Paradigmatic Controversies, Contradictions, and Emerging Confluences, Revisited. In The Sage Handbook of Qualitative Research, edited by Norman Denzin and Yvonna Linconln, 108-50. Los Angeles, London, New Delhi, Singapore, Washingon, and Melbourne: Sage Publications, Inc. 2018.

Lyon, David. Jesus in Dysneyland: Religion in Postmodern Times. Cambridge: Polity Press, 2000.

Madrigal Moreno, Flor, Jaime Gil Lafuente, Fernando Ávila Carreón, and Salvador Madrigal Moreno. "The Characterization of the Millennials and Their Buying Behavior.” International Journal of Marketing Studies 9, no. 5 (2017). DOI: 10.5539/ijms.v9n5p135

Mallimaci, Fortunato. "Creer por su propia cuenta en la ciudad de Buenas Aires en el siglo XXI." In Guía de la diversidad religiosa de Buenos Aires. Vol 2, edited by Floreal Forni, Fortunato Mallimaci and Luis Cárdenas, 15-31. Buenos Aires: Biblos, 2008.

. "Cuentapropismo religioso: creer sin ataduras. El nuevo mapa religioso en la Argentina Urbana." In Religión, política y sociedad: Pujas y transformaciones en la historia argentina reciente, edited by Aldo Ameigeiras and José Pablo Martín, 15-43. Buenos Aires: Prometeo Libros, 2008.

, ed. Modernidad, Religión y Memoria. Buenos Aires, Ediciones Colihue, 2008.

Mallimaci, Fortunato y Verónica Giménez Béliveau. "Creencias e increencia en el Cono Sur de América: Entre la religiosidad difusa, la pluralización del campo religioso y las relaciones con lo público y lo político. Revista Argentina de Sociología 5, no. 9 (2007): 44-63. http://www.scielo.org.ar/pdf/ras/v5n9/v5n9a04.pdf 
Nelson, Millicent, Matrecia S. L. James, Angela Miles, Daniel L. Morrell, and Sally Sledge. "Academic Integrity of Millennials: The Impact of Religion and Spirituality." Ethics \& Behavior 27, no.5 (2017): 385-400. DOI:

10.1080/10508422.2016.1158653

Nilan, Pam, and Carles Feixa. Global Youth?: Hybrid Identities, Plural Worlds. London and New York: Routledge, 2006.

Novella, Rafael, Andrea Repetoo, Carolina Robino, and Graciana Rucci. Millennials en América Latina y el Caribe: ¿trabajar o estudiar? Washington: Banco Interamericano de Desarrollo, 2018.

O'Brien, Martin, Sue Penna, and Colin Hay, eds. Theorising Modernity: Reflexivity, Environment, and Identity in Giddens' Social Theory. London and New York: Longman, 1999.

Parker Gumucio, Cristian. "Religión, cultura y política en América Latina: nuevos enfoques.” In Religión, política y cultura en América Latina: Nuevas miradas, edited by Cristian Parker Gumucio, 13-73. Santiago de Chile: Instituto de estudios Avanzados Universidad de Santiago de Chile and Asociación de Cientistas Sociales de la Religión del Mercosur, 2012.

PEW Research Center. "Millennials: Confident. Connected. Open to Change." February, 2010. http://www.pewresearch.org/wp-content/uploads/sites/3/2010/10/millennialsconfident-connected-open-to-change.pdf

. "Religion in Latin America: Widespread Change in a historically Catholic Region.” November 13, 2014. http://www.pewresearch.org/wpcontent/uploads/sites/7/2014/11/Religion-in-Latin-America-11-12-PM-fullPDF.pdf

. "Religion \& Public Live: Adults in the Miami Metro Area." Accessed January 4, 2019. http://www.pewforum.org/religious-landscape-study/metro-area/miamimetro-area/

. "Religion \& Public Live: Religious Landscape Study." Accessed January 4, 2019. http://www.pewforum.org/religious-landscape-study/

. "The Age Gap in Religion around the World." June 12, 2018. http://www.pewresearch.org/wp-content/uploads/sites/7/2016/03/Religion-andGender-Full-Report.pdf 
. "The Shifting Religious Identity of Latinos in the United States: Nearly One-inFour Latinos Are Former Catholics." May 7, 2014.

http://www.pewresearch.org/wp-content/uploads/sites/7/2014/05/Latinos-Religion07-22-full-report.pdf

Rückert, Arne, Laura Macdonald, and Arne Ruckert. Post-Neoliberalism in the Americas. New York: Palgrave Macmillan, 2009.

Sakaranaho, Tuula. "Religion and the Study of Social Memory." Temenos: Nordic Journal of Comparative Religion 47, no. 2 (2011): 135-58. http://ojs.tsv.fi/index.php/temenos/index

Scott, Sir Walter. Ivanhoe. Public Domain. Kindle Edition.

Smith, William, Carlos Acuña, and Eduardo Gamarra, eds. Latin American Political Economy in the Age of Neoliberal Reform: Theoretical and comparative Perspectives for the 1990s. New Brunswick and London: Transaction Publishers, 1994.

Snyder, Susana. Asylum-Seeking, Migration, and Church. Burlington: Ashgate Publishing Company, 2012.

Sökefeld, Martin. “Reconsidering Identity.” Antrhopos 96, no.2 (2001): 527-44.

Stepick, Alex, Terry Rey, and Sarah J. Mahler, eds. Churches and Charity in the Immigrant City: Religion, Immigration, and Civic Engagement in Miami. New Brunswick, New Jersey: Rutgers University Press, 2009.

Stoessel, Soledad. "Giro a la izquierda en la América Latina del siglo XXI: Revisando los debates académcios.” Polis Revista Latinoamericana 39 (2014): 1-22. http://polis.revues.org/10453

Tavory, Iddo. Summoned: Identification and Religious Life in a Jewish Neighborhood. Chicago and London: The University of Chicago Press, 2016.

Tweed, Thomas. Our Lady of the Exile: Diasporic Religion at a Cuban Catholic Shrine in Miami. New York: Oxford University Press, 1997. . Crossing and Dwelling: A Theory of Religion. Cambridge, Massachusetts, and London: Harvard University Press, 2008. Kindle Edition.

United States Census Bureau. “American FactFinder: Age and Sex 2013-2017 American Community Survey 5-Year Estimates.” Accessed January 14, 2019. https://factfinder.census.gov/faces/tableservices/jsf/pages/productview.xhtml?pid= ACS_17_5YR_S0101\&prodType=table 
. "QuickFacts: Miami-Dade County, Florida.” Accessed January 14, 2019. https://www.census.gov/quickfacts/fact/table/miamidadecountyflorida/PST045218\#

Vargas, Lluís Pla. “¿Identificación por el mercado? Los enfoques de Giddens, Bauman y Beck: Algunos argumentos críticos." Sociológica 28, n0.80 (2013). [citado 201901-29], pp.41-72. https://tinyurl.com/y86t2umw

World Population Review. "Miami, Florida Population 2019: Demographics, Maps, Graphs.” Accessed January 14, 2019. http://worldpopulationreview.com/uscities/miami-population/

Zong, Jie and Janne Batalova. "South American Immigrants in the United States." Migration Information Source (November, 2018).

https://www.migrationpolicy.org/article/south-american-immigrants-united-states/ 


\section{In-Depth Interviews}

Interview 01. Interview by Ernesto Fiocchetto. December 2018. Transcript. Interview 02. Interview by Ernesto Fiocchetto. December 2018. Transcript. Interview 03. Interview by Ernesto Fiocchetto. December 2018. Transcript. Interview 04. Interview by Ernesto Fiocchetto. January 2019. Transcript. Interview 05. Interview by Ernesto Fiocchetto. January 2019. Transcript. Interview 06. Interview by Ernesto Fiocchetto. January 2019. Transcript. Interview 07. Interview by Ernesto Fiocchetto. January 2019. Transcript. Interview 08. Interview by Ernesto Fiocchetto. January 2019. Transcript.

\section{Focus Group Sessions}

Focus Group 01. Session conducted by Ernesto Fiocchetto. December 2018. Transcript. Focus Group 02. Session conducted by Ernesto Fiocchetto. January 2019. Transcript. 